1

2

3

\title{
Hf and Nd isotopes in Early Ordovician to Early Carboniferous granites as monitors of crustal growth in the Proto-Andean margin of Gondwana
}

\author{
Juan A. Dahlquist ${ }^{1,2}$, Robert J. Pankhurst ${ }^{3}$, Richard M. Gaschnig ${ }^{4}$, Carlos W. Rapela ${ }^{5}$, César Casquet ${ }^{6}$, \\ Pablo H. Alasino ${ }^{7,2}$, Carmen Galindo ${ }^{6}$, Edgardo G. Baldo ${ }^{1}$ \\ ${ }^{1}$ CICTERRA-CONICET-UNC, Av. Vélez Sarsfield 1611, Pab. Geol., X5016CGA, Córdoba, Argentina \\ ${ }^{2}$ INGeReN-CENIIT-UNLaR. Av. Gob. Vernet y Apóstol Felipe. 5300, La Rioja, Argentina \\ ${ }^{3}$ British Geological Survey, Keyworth, Nottingham NG12 5GG, UK \\ ${ }^{4}$ Department of Geology University of Maryland College Park, Maryland 20742, USA \\ ${ }^{5}$ CIG-CONICET-UNLP, Calle 1 No 644, 1900, La Plata, Argentina \\ ${ }^{6}$ Universidad Complutense 28040 Madrid, Spain \\ ${ }^{7}$ CRILAR-CONICET, Entre Ríos y Mendoza. 5301, Anillaco, La Rioja, Argentina
}

\begin{abstract}
We report the first study integrating in situ $\mathrm{U}-\mathrm{Pb}$ and $\mathrm{Hf}$ isotope data from magmatic zircon and whole-rock Sm-Nd isotope data for granitic rocks of the Sierras Pampeanas, Argentina, in order to evaluate the Palaeozoic growth of the proto-Andean margin of Gondwana. Generation of Ordovician magmas dominantly involved crustal reworking and stabilization rather than the formation of new continental crust by juvenile material accretion, whereas Late Palaeozoic magmatism produced some limited continental growth, especially during the Early Carboniferous. Overall, the proto-Andean margin was shaped predominantly by the reworking of existing old crustal rocks rather than crustal growth.

Keywords: U-Pb dating, $\mathrm{Hf}$ and $\mathrm{Nd}$ isotopes, zircon, crustal growth.
\end{abstract}




\section{Introduction}

As the pre-eminent $\mathrm{U}-\mathrm{Pb}$ geochronometer zircon plays a key role in crustal evolution studies.

Recent analytical advances permit investigation of complex zircon grains at high spatial resolution, where the goal is to link $\mathrm{U}-\mathrm{Pb}$ ages to other geochemical information, such as $\mathrm{Hf}$ isotopic

composition. Thus zircon can provide time-stamped 'snapshots' of Hf isotope signatures of magmas throughout Earth's history, even at the scale of individual growth zones within a single grain. This information is an invaluable help to geochemists trying to distinguish magmatic events that added new mantle-derived material to the continental crust from those that recycled existing crust (e.g., Scherer et al., 2007; Siebel and Chen, 2010).

In this article we report in situ $\mathrm{U}-\mathrm{Pb}$ and $\mathrm{Hf}$ isotope data from zircons and whole-rock $\mathrm{Sm} / \mathrm{Nd}$ data from their host granites to evaluate the origin of the granitic magmas and consequently the building of the proto-Andean margin of Gondwana during three main Palaeozoic magmatic events known in the Sierras Pampeanas of NW Argentina.

\section{Regional setting}

The proto-Andean margin of Gondwana is a good example of an accretionary orogen that has been active since at least the Early Ordovician up to the present (Cawood, 2005), leading to the formation of different plutonic rocks during the Palaeozoic. Geochronological data and their interpretation in terms of major magmatic episodes allow the recognition of four main granitoid groups in the Eastern Sierras Pampeanas of NW Argentina (Fig. 1): Early Cambrian (Pampean), Early-Middle Ordovician (Famatinian), Middle-Late Devonian (Achalian) and Early Carboniferous. We have studied granitic rocks from the last three of these groups. Famatinian granitoids are typical calc-alkaline granites, formed in an active continental margin; those emplaced during the Achalian and Early Carboniferous events have dominantly A-type signatures. 
The Famatinian arc (Fig. 1) is widely accepted to have been constructed on continental crust (Pankhurst et al, 1998; Dahlquist and Galindo, 2004; Miller and Söllner, 2005; Dahlquist et al., 2008).In the Famatinian magmatic belt of the Sierras Pampeanas, Pankhurst et al. (2000) identified three distinct granite-types: dominant I-type, small-scale S-type, and tonalite-trondhjemitegranodiorite (TTG, confined to the Sierras de Córdoba, see Fig. 1 of Pankhurst et al., 2000). These three granite types can be distinguished petrologically, geochemically, and spatially, although all were emplaced within the 484-463 Ma interval (see also Dahlquist et al., 2008). Detailed petrological and geochemical studies of these rocks are given by Aceñolaza et al. (1996), Saavedra et al. (1998), Pankhurst et al. (1998, 2000), Dahlquist and Galindo (2004), Miller and Söllner (2005), Dahlquist (2002), Dahlquist et al. (2005, 2007, 2008), and Ducea et al. (2010).

The widespread Famatinian magmatism yielded extensive I-type intrusions (mostly tonalite, granodiorite and minor monzogranite and gabbro) with $\varepsilon \mathrm{Nd}_{\mathrm{t}}=-3$ to -6 (data from Pankhurst et al. 1998, 2000; Dahlquist and Galindo 2004; Dahlquist et al., 2008). Some gabbros in the Sierra de Valle Fértil reached a more radiogenic value of $\varepsilon \mathrm{Nd}_{\mathrm{t}}=-2.4$, and subordinate small-scale isolated Ordovician plutons of Na-rich granite located in the Pampean belt foreland (TTG suites) have $\varepsilon \mathrm{Nd}_{\mathrm{t}}=$ +1.6 to -0.2 . Most of the granitic rocks have $\mathrm{T}_{\mathrm{DM}}$ model ages between 1.7 and $1.5 \mathrm{Ga}$ and $\mathrm{Nd}$ isotopic signatures suggesting derivation from a composite Palaeo-Mesoproterozoic lithospheric section that included lower and upper crustal sources as well as the sub-lithospheric mantle (Rapela et al. 2008a; Dahlquist et al. 2008 and references therein). Thus, with the exception of the minor TTG suites, it is usually argued that the Famatinian magmatic arc reworked old lithospheric sources, with very little addition of juvenile material, although this view may need a degree of modification since the discovery of more juvenile Nd isotope compositions in the extreme west of the Sierra de Valle Fértil (Casquet et al., submitted). 
Dahlquist et al. (2008) concluded that: (i) the Famatinian magmatism was brief ( 484 to $\sim 463$

Ma), in remarkable contrast to the long-lived Mesozoic-Cenozoic cordilleran magmatism of the

Andes; and (ii) the Early to mid-Ordovician development of ensialic marine basins was synchronous with the emplacement of voluminous lithosphere-derived magmatism in the central region of the

Famatinian orogenic belt, which strongly contrasts with the Andean-type model for the production of magmas (Dahlquist and Galindo, 2004; Rapela et al., 2008a). This magmatism was completely extinguished during the mid-Ordovician and the marine sedimentary basins closed in the early Late Ordovician.

The ca. $2500 \mathrm{~m}^{2}$ Achala batholith in the Sierras de Córdoba (Fig. 1) was emplaced during the

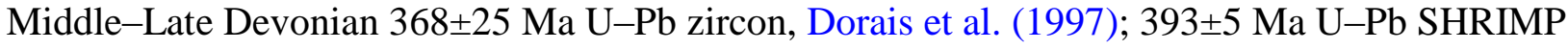
zircon, Stuart-Smith et al. (1999); 382 \pm 5 Ma Siegesmund et al. (2004); 369 \pm 9 Ma Rb-Sr wholerock, Pinotti et al. (2006) and 379 \pm 4 and 369 \pm 3 Ma U-Pb SHRIMP zircon, Rapela et al. (2008b) (Fig. 1). It is the largest of a series of intrusive granitic bodies in the Sierras Pampeanas that are conspicuously discordant to structures and rocks formed during the Cambrian (Pampean) and Ordovician (Famatinian) metamorphic events. Contact aureoles indicate shallow emplacement, usually less than 2 kbar (e.g., Baldo, 1992; Pinotti et al., 2002). Rapela et al. (2008b) concluded that the Achala batholith has an A-type signature. Sims et al. (1998), Stuart-Smith et al. (1999), and Siegesmund et al. (2004) considered the voluminous Devonian intrusive rocks in the Sierras de Córdoba and the eastern area of the Sierras de San Luis to have been emplaced during compression associated with Late Devonian low-grade shear zones, together defining the Achalian orogeny. According to this interpretation the Devonian granites, such as the Achala (Sims et al., 1998) and Cerro Áspero batholiths in Sierra de Córdoba (e.g., Pinotti et al., 2002, 2006), and the Las Chacras (Siegesmund et al., 2004) and Renca (Stuart-Smith et al., 1999) batholiths in Sierra de San Luis (Fig. 1), are not post-orogenic intrusions of the Famatinian Orogeny as proposed by Pankhurst and Rapela 
(1998), but belong to a distinct tectonomagmatic event. The Late Devonian compressional event is controversial and has been related to: i) collision of the suggested Chilenia terrane with the proto-

Pacific margin (Willner et al., 2011), ii) final collision between the Famatinian magmatic arc and the Pampean hinterland (Höckenreiner et al., 2003) and, recently, iii) push-pull tectonic switching episodes during Devonian and Carboniferous time, resulting from flat-slab/roll-back subduction in the Pacific margin (Alasino et al., 2012). The A-type geochemical signature of the Achala batholith (Rapela et al., 2008b) strongly suggests generation of intacratonic magmas in a dominantly extensional regime with subsequent lithosphere thinning (Early-Middle Devonian?), followed by Late Devonian horizontal shortening and Early Carboniferous lithosphere stretching (see tectonic switching model of Collins, 2002).

In Carboniferous times, isolated and scattered granitic pluton with anorogenic signature occurred along more than $1000 \mathrm{~km}$ in the Sierras Pampeanas of NW Argentina (see Dahlquist et al., 2010, Fig. 1). It is represented by small and scattered plutons, usually sub-circular, intruded mainly along prominent shear zones active in the Early Carboniferous (Dahlquist et al., 2010). Host rocks to this Carboniferous magmatism formed during three main periods of magmatic and metamorphic activity: Middle Cambrian (Pampean orogeny), Early-Middle Ordovician (Famatinian orogeny), and MiddleLate Devonian (Achalian event) (Pankhurst et al., 1998, 2000; Rapela et al., 1998; Sims et al., 1998; Dahlquist et al., 2008; Rapela et al., 2008b; Vaughan and Pankhurst, 2008; Spagnuolo et al., 2011; Tohver et al., 2011; Alasino et al., 2012).

The geodynamic setting of the Carboniferous magmatism remains controversial. Some authors have suggested that it resulted from crustal reheating as the final phase of a protracted Famatinian orogeny extending from Ordovician to Early Carboniferous (e.g., Grissom et al., 1998; Llambías et al., 1998; Höckenreiner et al., 2003; Grosse et al., 2009). Others have argued for a distinctive and extended Achalian orogenic event in the Devonian-Early Carboniferous (e.g., Sims et al., 1998; 
Stuart-Smith et al., 1999; Siegesmund et al., 2004; López de Luchi et al., 2004; Dahlquist et al.,

\section{Analytical methods}

\subsection{Geochronology}

Samples chosen for U-Pb zircon geochronology were prepared and analysed at the School Earth and Environmental Sciences (SEES), Washington State University (WSU). As were crushed and pulverized using a jaw crusher and disc mill followed by heavy mineral concentration using a

Gemini table. Additional density separation was carried out using methylene iodide and magnetic separation using a Franz magnetic separator. Zircons (> 90\% pure) were mounted in epoxy within $2.5 \mathrm{~cm}$ diameter rings, polished to expose zircon interiors, and imaged with a Scanning Electron Microscope in cathode-luminescence (CL) mode at the University of Idaho.

All LA-ICP-MS U-Pb analyses were conducted at Washington State University using a New Wave Nd:YAG UV 213-nm laser coupled to a ThermoFinnigan Element 2 single collector, doublefocusing, magnetic sector ICP-MS. Operating procedures and parameters are discussed in greater depth by Gaschnig et al. (2010) and Chang et al. (2006) and are only briefly outlined here. Laser spot 
size and repetition rate were $30 \mu \mathrm{m}$ and $10 \mathrm{~Hz}$, respectively. He and Ar carrier gases delivered the sample aerosol to the plasma. Time-independent (or static) fractionation is the largest source of uncertainty in LA-ICP-MS U-Pb geochronology and results from mass and elemental static fractionation in the plasma and also poorly understood laser-matrix effects (Kosler and Sylvester, 2003). It is corrected by normalizing $\mathrm{U} / \mathrm{Pb}$ and $\mathrm{Pb} / \mathrm{Pb}$ ratios of the unknowns to the zircon standards (Chang et al., 2006). For this study we used two zircon standards: Peixe, with an age of $564 \mathrm{Ma}$ (Dickinson and Gehrels, 2003), and FC-1, with an age of 1,099 Ma (Paces and Miller, 1993). Results are summarized in Table 1 and full data are given in Table 2 (we suggest Table 2 as Electronic Appendix 1).

\subsection{Hf Isotope Analysis}

In-situ LA-MC-ICP-MS Hf isotope analyses were conducted at WSU using a New Wave $213 \mathrm{~nm}$ UP Nd:YAG laser coupled to a Thermo-Finnigan Neptune MC-ICP-MS with 9 Faraday collectors. The laser was operated at a pulse rate of $10 \mathrm{~Hz}$ and power density of $10-12 \mathrm{~J} / \mathrm{cm}^{2}$ with a spot size of $40 \mu \mathrm{m}$, except in a few cases where smaller grains and narrower zones required a smaller spot size of $30 \mu \mathrm{m}$. The carrier gas consisted of purified He with small quantities of $\mathrm{N}_{2}$ to minimize oxide formation and increase sensitivity. Analyses consisted of 60 one-second measurements in static mode.

The greatest obstacle in LA-MC-ICP-MS Hf isotopic analysis is the isobaric interference of ${ }^{176} \mathrm{Yb}$ and ${ }^{176} \mathrm{Lu}$ on ${ }^{176} \mathrm{Hf}$ (e.g., Woodhead et al., 2004). Despite the extremely low Lu/Hf in zircon, ${ }^{176} \mathrm{Yb}$ can comprise more than $10 \%$ of the total signal at mass 176 and provides the largest source of uncertainty in the measurement. A partly empirical approach was used to correct for the $\mathrm{Yb}$ interference, in which a modified $\mathrm{Yb}$ isotopic composition was calculated with $\mathrm{Yb}$ mass bias determined by the relationship $\beta_{\mathrm{Yb}}=\mathrm{x} * \beta_{\mathrm{Hf}}$. The value for $\mathrm{x}$ was determined by analyzing the zircon standards 91500, FC1, Peixe, GJ1, Mudtank, R33, Pleisovice, QGNG, and Temora and adjusting the 
$\mathrm{x}$ value to best fit the known ${ }^{176} \mathrm{Hf} /{ }^{177} \mathrm{Hf}$ values previously determined on chemically purified composition of the unknowns.

Due to the difficulty in correcting for the $\mathrm{Yb}$ interference and other sources of error such as instrumental bias and matrix effects, the internal measurement error by itself is often considerably less than the total uncertainty, which is often difficult to estimate. Based on the deviation of ${ }^{176} \mathrm{Hf} /{ }^{177} \mathrm{Hf}$ values determined by the in situ method on the standards from the values determined by solution analysis, the total uncertainty for individual analyses is approximately $\pm 3 \sigma$ units.

Present day and initial $\varepsilon_{\mathrm{Hf}}$ values were calculated using CHUR compositions of ${ }^{176} \mathrm{Hf} /{ }^{177} \mathrm{Hf}_{\text {today }}=$ 0.282785 and ${ }^{176} \mathrm{Lu} /{ }^{177} \mathrm{Hf}=0.0336$ (Bouvier et al., 2008) and a ${ }^{176} \mathrm{Lu}$ decay constant of $1.867 \mathrm{e}-11$ (Scherer et al., 2001; Söderlund et al., 2004). The initial ${ }^{176} \mathrm{Hf} /{ }^{177} \mathrm{Hf}$ at the time of zircon crystallization were used to calculate the hypothetical present-day ${ }^{176} \mathrm{Hf} /{ }^{177} \mathrm{Hf}$ of the zircons' parent rock based on an average crustal ${ }^{176} \mathrm{Lu} /{ }^{177} \mathrm{Hf}$ of 0.015 (Goodge and Vervoort, 2006). The present day ${ }^{176} \mathrm{Hf} /{ }^{177} \mathrm{Hf}$ and assumed rock ${ }^{176} \mathrm{Lu} /{ }^{177} \mathrm{Hf}$ values were then used to calculate a traditional TDM using the equation: $(1 / \ddot{\mathrm{e}}) * \ln \left[\left({ }^{176} \mathrm{Hf} /{ }^{177} \mathrm{Hf}(\right.\right.$ sample $\left.)-{ }^{176} \mathrm{Hf} /{ }^{177} \mathrm{Hf}(\mathrm{DM})\right) /\left({ }^{176} \mathrm{Lu} /{ }^{177} \mathrm{Hf}\right.$ (average crust)$\left.\left.{ }^{176} \mathrm{Lu} /{ }^{177} \mathrm{Hf}(\mathrm{DM})\right)\right]$. For the depleted mantle parameters, ${ }^{176} \mathrm{Hf} /{ }^{177} \mathrm{Hf}(\mathrm{DM})=0.283225$ and ${ }^{176} \mathrm{Lu} /{ }^{177} \mathrm{Hf}$ $(\mathrm{DM})=0.038512($ Vervoort and Blichert-Toft, 1999).

\subsection{Sm-Nd Isotope Analysis}

Sm-Nd determinations of representative dated granitic samples with Hf isotope zircon data were carried out at Washington State University. For Nd whole-rock isotopic analyses, $\sim 0.25 \mathrm{~g}$ aliquots of whole-rock powders were dissolved at high pressure in sealed, steel-jacketed Teflon bombs with a 10:1 mixture of concentrated $\mathrm{HF}$ and $\mathrm{HNO}_{3}$ acids at $150^{\circ} \mathrm{C}$ for 5 to 7 days. After conversion from fluorides to chlorides, samples were spiked with a mixed ${ }^{149} \mathrm{Sm}-{ }^{150} \mathrm{Nd}$ tracer. LREE were initially separated on cation exchange columns using AG 50W-X8 (200-400 mesh) resins; Nd and Sm were 
then separated from the LREE aliquot on columns with HDEHP-coated Teflon powder and $\mathrm{HCl}$

(Vervoort and Blichert-Toft, 1999).

All analyses were conducted on a Thermo-Finnigan Neptune MC-ICP-MS. Nd analyses were corrected for mass fractionation using ${ }^{146} \mathrm{Nd} /{ }^{144} \mathrm{Nd}=0.7219$ and normalized using Ames and La Jolla Nd standards. Sm analyses were corrected for fractionation using ${ }^{147} \mathrm{Sm} /{ }^{152} \mathrm{Sm}=0.56081$. All mass fractionation corrections were performed using an exponential law.

The uncertainties on $\mathrm{Nd}$ isotopic measurements reflect in-run error only and are presented as two standard errors as reported by Bouvier et al. (2008, Table 2). The full uncertainties are better assessed from the reproducibility of the standards. Average reproducibility ( 2 standard deviations) of ${ }^{143} \mathrm{Nd} /{ }^{144} \mathrm{Nd}$ on Ames standard during the period of analysis was \pm 0.000020 .

The decay constants used in the calculations are the values $\lambda^{147} \mathrm{Sm}=6.54 \times 10^{-12}$ year $^{-1}$ recommended by the IUGS Subcommission for Geochronology (Steiger and Jaëger, 1977). Epsilon$\mathrm{Nd}(\varepsilon \mathrm{Nd})$ values were calculated relative to a CHUR: $\left({ }^{143} \mathrm{Nd} /{ }^{144} \mathrm{Nd}\right)_{\text {today }} \mathrm{CHUR}=0.512638$;

$\left({ }^{143} \mathrm{Sm} /{ }^{144} \mathrm{Nd}\right)_{\text {today }} \mathrm{CHUR}=0.1967$ (Goldstein et al., 1984; Jacobsen and Wasserburg, 1980). T $\mathrm{DM}$ was calculated according to DePaolo et al. (1991).

The results are reported in Table 4, together with published (and in some cases recalculated) data for other samples selected for $\mathrm{Nd}$ isotope analysis, as well as representative equivalent samples from the same igneous bodies.

\subsection{Geochemistry}

Whole-rock major elements were determined for three igneous samples at the Washington State University GeoAnalytical Lab, using a ThermoARL sequential X-ray fluorescence spectrometer, following the procedure described by Johnson et al. (1999). Trace elements were determined in the same samples using ICP-MS, following the procedure described in http://www.sees.wsu.edu/Geolab/note/icpms.html. 


\section{Hf in zircon and whole-rock $\mathrm{Nd}$ isotope data}

Hf isotopes were determined from the magmatic growth rim zone of 14 zircons (Table $3 \mathrm{a}, \mathrm{b}$ and summarized in Table 1, we suggest Table 3b as Electronic Appendix 2) of which had been first dated by LA-ICP-MS U-Pb isotope analysis (Table 2). Only zircon areas shown to have crystallized during the primary magmatic event were analysed for Hf isotopes. Inherited core zircon ages in Famatinian granitic rocks define mainly Mesoproterozoic-early Neoproterozoic (ca. 1150-850 Ma) and Neoproterozoic - early Cambrian (ca. 720-530 Ma) populations (data from Ducea et al., 2010), and 
inherited zircons with Ordovician ages have been reported from Carboniferous plutons by Grosse et

al. (2009) and Fogliata et al. (2012). Whole-rock chemistry of the rocks with Hf and Nd isotopes data is reported in Table 5 (we suggest Table 5 as Electronic Appendix 3). Chemical data are not discussed here, but they are included as complementary information for those rocks with $\mathrm{Hf}$ and $\mathrm{Nd}$ isotope data.

The $\varepsilon_{\mathrm{Hft}}$ values for magmatic zircons are plotted as a function of the corresponding whole-rock $\mathrm{Nd}$ isotope composition at the time of crystallization $\left(\varepsilon_{\mathrm{Ndt}}\right)$ and also as a function of crystallization age (Table 3a, 5 and Fig. 2). As in the general study reported by Kemp et al. (2007), an important feature of the $\mathrm{Hf}$ isotope data is the significant range of $\varepsilon_{\mathrm{Hft}}$ values exhibited by zircons within the same sample (up to $10 \varepsilon$ units). Such variations can only be reconciled by the operation of open system processes that are capable of changing the ${ }^{176} \mathrm{Hf} /{ }^{177} \mathrm{Hf}$ ratio of the melt from which the zircons precipitated. Considering the scale of our work, where the objective is to evaluate the predominant Hf isotopic compositions of the magma sources, we have selected what we consider to be the most representative values for each sample, eliminating 'extreme' values (compare Table 3a and 3b) that diverge by more than $\sim 3 \varepsilon_{\mathrm{Hft}}$ units (i.e., the total uncertainty estimated for individual analyses, see Section 3), with exception of FAM-7086 and VEL-6017 (see explanation below). In some cases no such filtering was necessary (Table $3 \mathrm{a}, \mathrm{b}$ ). However, extreme values observed in some samples (Table 3b) are taken into account in this study because they could represent variability in the main magma source (e.g., juvenile material contribution, deep metasediments, pre-existing crystalline basement) or contaminants (e.g., upper crustal wall-rocks).

The Early-Middle Ordovician magmatism is by far the most voluminous of the Sierras Pampeanas (Fig. 1) and is thus highly significant for crustal evolution in this region. These granitic rocks are calc-alkaline (composition in Table 5) and represent an active continental margin. For these samples $\varepsilon_{\mathrm{Hft}}$ and $\varepsilon_{\mathrm{Ndt}}$ values range from -3.3 to -14.7 and -3.3 to -6.3 , respectively, with average $\mathrm{T}_{\mathrm{DM}} \mathrm{Hf}$ and 
$\mathrm{T}_{\mathrm{DM}} \mathrm{Nd}$ ranging from 1.5 to $2.2 \mathrm{Ga}$ and 1.4 to $1.7 \mathrm{Ga}$, respectively (Tables $1,3 \mathrm{a}, 4$ and Fig. 2). In

5

particular, sample FAM-7086 has very low zircon $\varepsilon_{\mathrm{Hft}}$ and whole-rock $\varepsilon_{\mathrm{Ndt}}$ values, indicating

probable derivation from a Precambrian supracrustal source. However, the more mafic rocks such as

SVF-577 $\left(\mathrm{SiO}_{2}=42.6 \%\right)$ also have $\mathrm{Hf}$ and $\mathrm{Nd}$ isotope compositions requiring a major crustal

component. The average $\varepsilon_{\mathrm{Ndt}}$ value (calculated with $\mathrm{t}=473 \mathrm{Ma}$ ) for Famatinian granitoids using data from Dahlquist et al. (2010) is -5.1 and $\mathrm{T}_{\mathrm{DM}}$ is $1.6 \mathrm{Ga}$ (Table 4). The few extreme values observed in some samples of Ordovician age (ANC-11030a, FAM-7086, and SVF-577, Table 3b) do not significantly change the conclusion that old continental sources were involved in Famatinian magmatism, predominantly contaminated by different older continental materials with distinctive isotopic signature (e.g., deep crystalline basement or upper crustal wall-rocks such as metasediments).

During the Middle-Late Devonian, magmatism was developed in a foreland position away from the orogenic front in the west (Fig. 1). F-U-REE rich A-type granites formed at this time (composition in Table 5). The Achala granite, the largest batholith in the Sierras Pampeanas, is discordant to country rock fabrics formed during the Cambrian (Pampean) and Ordovician (Famatinian) events (Rapela et al., 2008b). It has $\varepsilon_{\mathrm{Hft}}$ and $\varepsilon_{\mathrm{Ndt}}$ values ranging from -3.6 to -5.8 and -4.0 to -6.5 , respectively (Tables $1,3 a, 4$ and Fig. 2). Isotopic data from the Achala batholith show $\varepsilon_{\text {Ndt }}$ values of -4.0 to -6.5 (mean $=-4.8$, data in Table 4 ) for the main granitic facies (all values calculated with $t=369 \mathrm{Ma})$. Significantly more $\varepsilon_{\mathrm{Hft}}$ negative values were observed in one sample only (ACH-140, Table 3b), suggesting contamination by much older metasediments at depth.

The Early Carboniferous A-type granites (composition in Table 5) were intruded when the region was already cratonized and occur as small scattered plutons (Fig. 1) emplaced in a dominantly extensional setting, within older metamorphic and igneous rocks; many of them are aligned along a large reactivated shear zone (Rapela et al., 2001; Dahlquist et al., 2010). These granites have $\varepsilon_{\mathrm{Hft}}$ and 
$\varepsilon_{\mathrm{Ndt}}$ values ranging from -6.7 to +2.6 and -0.5 to -3.6 , respectively (Tables $1,3 \mathrm{a}, 4$ and Fig. 2 ). The 5 average $\varepsilon_{\text {Ndt }}$ for Carboniferous granitoids (all values calculated with $t=343 \mathrm{Ma}$ ) using data from

Dahlquist et al. (2010) is -2.3 (Tables 1 and 4). Extreme values are observed in the samples of Carboniferous age (FIA-17, HUA-12, and ZAP-33, Table 3b), suggesting variable crustal contamination. An exception is FAM-177, which has an isotopic signature that suggests juvenile material in the source (Table 3a). VEL-6017 has two contrasting isotopic compositions suggesting crustal and juvenile material in the source (Table 3a).

\section{Implications for crustal growth in the proto-Andean margin of Gondwana}

Zircon Hf and whole-rock Nd isotopic signatures in the Early-Middle Ordovician calc-alkaline granitic magmas were predominantly derived from pre-existing continental crust and thus represent

to a large extent recycling of old crustal rocks (Fig. 2) as suggested by Pankhurst et al. (2000), Rapela et al. (2008a), and Dahlquist et al. (2008). As argued by Rapela et al. (2008a), the classical Andean model for the magmas generation, invoking strong mantle contribution (e.g., Pitcher, 1979;

Wilson, 1989; Parada et al., 1999; Hervé et al., 2007; and references therein) does not seem to apply to these Ordovician calc-alkaline granites. However, this view may need a degree of modification since the recent discovery of more juvenile $\mathrm{Nd}$ isotope compositions in the extreme west of the Sierra de Valle Fértil (Casquet et al., submitted).

Taking into account the results reported in Section 4, the scenario showed in Fig. 3a is proposed for generation of the voluminous Ordovician calc-alkaline magmas. A suite of igneous rocks of Grenvillian age (1.2-1.3 Ga) crops out in the nearby Western Sierras Pampeanas (Rapela et al., 2010), and we suggest that such rocks could have been the main source for Famatinian magmatism. Previous $\mathrm{U}-\mathrm{Pb}$ and $\mathrm{Hf}$ determinations on zircon from small outcrops of Famatinian metaigneous rocks in La Pampa province (U-Pb zircon SHRIMP ages ranging from ca. 476 to $466 \mathrm{Ma}$ ) reveal 
similar results (Chernicoff et al., 2010), with negative $\varepsilon_{\mathrm{Hft}}$ (from -3.6 to -5.0) and average Lu-Hf two

stages model ages of ca. 1.7 Ga.

Hf and $\mathrm{Nd}$ data from the Achala granites suggest that these A-type granitic magmas were also largely derived from the recycling of old crustal rocks (Fig. 2). Consistent with this conclusion are the zircon age patterns of porphyritic granites reported by Rapela et al. (2008b), which show inherited components commonly found in the Cambrian metasedimentary country rocks of the batholith and therefore are a likely source component for these granites. However, Rapela et al. (2008b) have suggested the Achalian granites cannot be entirely derived from a Pampean basement source, as the $\mathrm{Nd}$ isotopic composition of the basement is well bracketed within an even more 'crustal' isotopic range $\left(\varepsilon_{\mathrm{Nd} 520}=-4.5\right.$ to -7.5 ; Rapela et al., 2008b). Rapela et al. (2008b, data listed in Table 4) reported similar $\varepsilon_{\text {Ndt }}(-4.0)$ for monzogranites from the same batholith. They found rather more radiogenic $\mathrm{Nd}$ in small-scale tonalite and leucogranites bodies $\left(\varepsilon_{\mathrm{Ndt}}=-1.2\right.$ to -1.9 , mean $=-1.6$, and $\varepsilon_{\mathrm{Ndt}}=-1.1$ to -1.4 , respectively). These minor intrusions could represent a more juvenile magma contribution ascending through of hypothetical local conduits.

The acid-to-intermediate component in a mixture is likely to dominate the Sm-Nd composition of the resultant magma due to its higher Sm and Nd contents. As reported by Kemp et al. (2007), when supracrustal material is reworked by juvenile magmas the $\mathrm{Nd}$ isotope ratios of the resulting bulk magma can camouflage the juvenile component. Conversely, the zircon can crystallize sufficiently early and to retain vestiges of the original isotope signature (Kemp et al., 2007). Thus, the zircon Hf data could be considered more robust in constraining the source of the Middle-Late Devonian A-type magmas. The $\varepsilon_{\mathrm{Hft}}$ and $\varepsilon_{\mathrm{Ndt}}$ values (Table $3 \mathrm{a}, \mathrm{b}, 4$ and Fig. 2) strongly suggest a dominant older crustal component (average $\mathrm{T}_{\mathrm{DM}} \mathrm{Hf}$ and $\mathrm{T}_{\mathrm{DM}} \mathrm{Nd}$ values ranging from 1.5 to 1.6 and 1.4 to 1.6, respectively), and a scenario similar to that shown in Fig. $3 \mathrm{~b}$ is assumed for the generation of A-type magmas during the Middle-Late Devonian. As noticed by Nelson (1992), high abundances of $\mathrm{P}_{2} \mathrm{O}_{5}$ (up to 3.3 
wt.\%) and of volatiles such as F (up to $1 \%$ ) could readily explained by the involvement of sediment in the source. Achala granites have biotite with very high F content (mean $=2.1 \%$ ); they bear unusual enclaves characterized by $89-93 \%$ biotite with high $\mathrm{FeO} / \mathrm{MgO}$ ratios (mean 3.1) and 7-11\% apatite with high F contents (mean 3.5\%); and they have abundant zircon and monazite together with scarce oxides as accessory minerals (data from Dorais et al., 1997). The modal mineralogy produces unusual bulk-rock compositions, including enhanced $\mathrm{P}_{2} \mathrm{O}_{5}=5.4$ wt. $\%, \mathrm{~F} \sim 6-7$ wt. $\%$, and very high $\mathrm{U}=181 \mathrm{ppm}, \mathrm{Zr}(2,581 \mathrm{ppm})$ and $\Sigma \mathrm{REEs}=4,500 \mathrm{ppm}$ contents (see NPE-10 sample in Table 5). We have therefore incorporated a petrogenetic scenario involving sediment contamination (Fig. 3b) following the geotectonic model discussed by Alasino et al. (2012) for the Late Paleozoic.

Grosse et al. (2009) and Fogliata et al. (2012) reported the presence of zircons with Carboniferous crystallization ages containing inherited zircon with Ordovician ages, and they consequently invoked significant participation of Ordovician meta-granitoids in the source of the Early Carboniferous Atype granites. However, the Carboniferous magmas could not have been entirely derived by remelting of the Ordovician granites because their $\varepsilon_{\text {Ndt }}$ values are less negative $(+0.6$ to -4.8 at 323 to $354 \mathrm{Ma}$ ) than those of the Famatinian granitoids of 320-360 Ma (-4.8 to -8.5, Dahlquist et al., 2010). Thus, the additional participation of an asthenospheric component is required to satisfy the $\varepsilon_{\mathrm{Ndt}}$ and $\varepsilon_{\text {Hft }}$ values calculated for the Early Carboniferous granitoids. Recently, Alasino et al. (2012) concluded that the Carboniferous granitic rocks overall show west-to-east mineralogical and isotopic regional zonation indicating that magma genesis involved a greater contribution of juvenile material of mantle character towards the west. The $\varepsilon_{\mathrm{Hft}}$ values reported here are consistent with the conclusions of Alasino et al., (2012) implying continental growth by addition of juvenile material in a foreland region, in particular for the Cerro La Gloria pluton with $\varepsilon_{\mathrm{Hft}}=+2.6$ (Fig. 1 and Table 3a). Thus, a petrogenetic model similar to that of Kemp et al. (2007), for plutonic rocks of the Lachlan Fold Belt (SE Australia), invoking interaction between crust of hypothetical Ordovician and 
Mesoproterozoic ages and juvenile magmas could also be applied to the generation of Eastern Sierras Pampeanas magmas during the Early Carboniferous (Fig. 3c).

A striking feature evident from the new data is that the Early-Middle Ordovician magmas from which most zircons crystallized were largely derived by melting of pre-existing old crustal rocks, without direct participation of the asthenospheric mantle. As noted above, the Early-Middle Ordovician magmatism is by far the most voluminous magmatism in the Sierras Pampeanas (Fig. 1) and represents the main magmatic event for the crustal development in this region of the protoAndean margin of Gondwana. The Middle-Late Devonian magmas resulted from reworking of supracrustal material in a foreland region, probably modified by a limited juvenile magma contribution. The Early Carboniferous magmas resulted in part from reworking of supracrustal material in a largely cratonized region, but with variably more significant proportions of juvenile magmas.

\section{Acknowledgments}

Financial support was provided by PIP-01940 (CONICET), Spanish CGL2009-07984/BTE, PICT 1009 (FONCyT), SECyT UNLaR Exp. N 7759/2008, PID Res. 000121 MINCyT Córdoba, and a CONICET external fellowship awarded to J.A. Dahlquist for his research stay at Washington State University, supervised for the Professor J. Vervoort. J.A. Dahlquist thanks Professor J. Vervoort for their comments on the data, and J. Vervoort, V. Valencia, G. Hart, and C. Knaack for their assistance with use of the LA-ICP-MS. 


\section{References}

Aceñolaza, F.G., Miller, H., Toselli, A.J., 1996. Geología del Sistema de Famatina. In: Aceñolaza,

F.G., Miller, H., Toselli, A.J. (Eds.), Geología del Sistema de Famatina. Münchner Geologische Hefte, Reihe A 19(6), 412 pp.

Alasino, P.H., Dahlquist, J.A., Pankhurst, R.J., Galindo, C. Casquet, C., Rapela, C.W., Larrovere, M., Fanning, C.M., 2012. Early Carboniferous sub- to mid-alkaline magmatism in the Eastern Sierras Pampeanas, NW Argentina: a record of crustal growth by the incorporation of mantlederived material in an extensional setting. Gondwana Research. Doi:10.1016/j.gr.2011.12.011

Baldo, 1992. Estudio petrológico y geoquímico de las rocas ígneas y metamórficas entre Pampa de

Olaen y Characato. Extremo norte de la Sierra Grande de Córdoba. República Argentina. Tesis Doctoral, Universidad Nacional de Córdoba, (unpublished). pp. 305.

Bouvier, A., Vervoort, J.D., Hatchett, J.P., 2008. The Lu-Hf and Sm-Nd isotopic composition of CHUR: Constraints from unequilibrated chondrites and implications for the bulk composition of terrestrial planets. Earth and Planetary Science Letters 273, 48-57.

Casquet, C., Rapela, C.W., Pankhurst, R.J., Baldo, E.G., Galindo, C., Fanning, C.M., Dahlquist, J.A., Submitted. Famatinian magmatic arc, juvenile magmatism, U-Pb SHRIMP zircon dating,

Gondwana, Sierras Pampeanas. Gondwana Research Letters.

Cawood, P.A., 2005. Terra Australis Orogen: Rodinia breakup and development of the Pacific and Iapetus margins of Gondwana during the Neoproterozoic and Paleozoic. Earth-Science Reviews $69,249-279$.

Cawood, P.A., Kröner, A., Collins, W.J., Kusky, T.M., Mooney, W.D. y Windley, B.F., 2009. Accretionary orogens through Earth history. In: Cawood, P.A., Kröner, A., (Eds.), Geological Society, London, Special Publications 318, 1-36. 
Chang, Z., Vervoort, J. D., McClelland, W. C., and Knaack, C., 2006, U-Pb dating of zircon by LA5

ICP-MS: Geochemistry, Geophysics, Geosystems, 7 Q05009, 1-14.

Chernicoff, C.J., Zappettini, E.O., Santos J.O.S., Allchurch, S., McNaughton, N.J., 2010. The southern segment of the Famatinian magmatic arc, La Pampa Province, Argentina. Gondwana Research 17, 662-675.

Collins, W.J., 2002. Hot orogens, tectonic switching, and creation of continental crust. Geology 30, $535-538$.

Dahlquist, J.A., 2002. Mafic microgranular enclaves: early segregation from metaluminous magma (Sierra de Chepes), Pampean Ranges, NW Argentina. Journal of South American Earth Sciences $15,643-655$.

Dahlquist, J.A., Galindo, C., 2004. Geoquímica isotópica de los granitoides de la sierra de Chepes: un modelo geotectónico y termal, implicancias para el orógeno famatiniano. Revista de la Asociación Geológica Argentina 59, 57-69.

Dahlquist, J.A., Rapela, C.W., Baldo, E.G., 2005. Cordierite-bearing S-Type granitoids in the Sierra de Chepes (Sierras Pampeanas): petrogenetic implications. Journal of South American Earth Sciences 20, 231-251.

Dahlquist, J.A., Pankhurst, R.J., Rapela, C.W., Casquet, C., Fanning, C.M., Alasino, P., Baez, F.M., 2006. The San Blas Pluton: an example of Carboniferous plutonism in the Sierras Pampeanas, Argentina. Journal of South American Earth Sciences 20, 341-350.

Dahlquist, J.A., Galindo, C., Pankhurst, R.J., Rapela, C.W., Alasino, P.H., Saavedra, J., Fanning, C.M., 2007. Magmatic evolution of the Peñón Rosado granite: petrogenesis of garnet-bearing granitoids. Lithos 95, 177-207.

Dahlquist, J.A., Pankhurst, R.J., Rapela, C.W., Galindo, C., Alasino, P., Fanning, C.M., Saavedra, J., Baldo, E., 2008. New SHRIMP U-Pb data from the Famatina Complex: constraining Early-mid 
Ordovician famatinian magmatism in the Sierras Pampeanas, Argentina. Geologica Acta 6, 319333.

Dahlquist, J.A., Alasino, P.H., Eby, G.N., Galindo, C., Casquet, C., 2010. Fault controlled Carboniferous A-type magmatism in the proto-Andean foreland (Sierras Pampeanas, Argentina): Geochemical constraints and petrogenesis. Lithos 115, 65-81.

Dahlquist, J.A., Alasino, Bello, C., Submitted. Origin of unusual biotite-apatite bodies, Achala batholith, Argentina. Journal of South American Earth Sciences.

DePaolo, D.J., Linn, A.M., Schubert, G., 1991. The continental crustal age distribution: methods of determining mantle separation ages from $\mathrm{Sm}-\mathrm{Nd}$ isotopic data and application to the southwestern United States. Journal Geophysical Research 96, 2071-2088.

Dickinson, W.R. \& Gehrels, G.E., 2003. U-Pb ages of detrital zircons from Permian and Jurassic eolian sandstones of the Colorado Plateau, USA: paleogeographic implications. Sedimentary Geology 163, 29-66.

Dorais, M., Lira, R., Chen, Y., Tingey, D. 1997. Origin of biotite-apatite-rich enclaves, Achala Batholith, Argentina. Contributions to Mineral and Petrology 130, 31-46.

Ducea, M.N., Otamendi, J.E., Bergantz, G., Stair, K.M., Valencia, V.A., Gehrels, G.E., 2010. Timing constraints on building an intermediate plutonic arc crustal section: $\mathrm{U}-\mathrm{Pb}$ zircon geochronology of the Sierra Valle Fértil-La Huerta, Famatinian arc, Argentina. Tectonics 29, TC4002, 21-22.

Fogliata, A.S., Báez, M.A., Hagemann, S.G., Santos, J.O, Sardi, F., 2012. Post-orogenic, Carboniferous granite-hosted Sn-W mineralization in the Sierras Pampeanas Orogen, Northwestern Argentina. Ore Geology Reviews 45, 16-32.

Gaschnig, R.M., Vervoort, J.D., Lewis, R.S., McClelland, W.C., 2010. Migrating magmatism in the northern US Cordillera: in situ U-Pb geochronology of the Idaho batholiths. Contributions to Mineralogy and Petrology 159, 863-883. 
Goldstein, S. J.; O`Nions, R.K.; Hamilton, P.J. 1984., A Sm.Nd isotopic study of atmospheric dusts and particulates from major river systems. Earth and Planetary Science Letters 70, 221236.Grissom, G.C., Debari, S.M., Snee, L.W., 1998. Geology of the Sierras de Fiambalá, northwestern Argentina: implications for Early Palaeozoic Andean tectonics. In: Pankhurst, R.J., Rapela, C.W. (Eds.), The Proto-Andean Margin of Gondwana: Journal of the Geological Society, London, Special Publications 142, 297-323.

Goodge, J. W., and Vervoort, J. D., 2006. Origin of Mesoproterozoic A-type granites in Laurentia: Hf isotope evidence. Earth and Planetary Science Letters, 243, 711-731.

Grosse, P., Söllner, F., Baéz, M.A., Toselli, A.J., Rossi, J.N., de la Rosa, J.D., 2009. Lower Carboniferous post-orogenic granites in central-eastern Sierra de Velasco, Sierras Pampeanas, Argentina: U-Pb monazite geochronology and $\mathrm{Sr}-\mathrm{Nd}$ isotopes. International Journal of Earth Sciences 98, 1001-1025.

Hervé, F., Pankhurst, R.J., Fanning, C.M., Calderón, M. \& Yaxley, G.M., 2007. The South

Patagonian batholith: 150 my of granite magmatism on a static plate margin. Lithos 97: 373-394.

Höckenreiner, M., Söllner, F., Miller, H., 2003. Dating the TIPA shear zone: an early Devonian terrane boundary between the Famatinian and Pampean systems (NW Argentina). Journal of South America Earth Sciences 16, 45-66.

Jacobsen S. B., Wasserburg G. J.,1980. Sm-Nd isotopic evolution of chondrites. Earth and Planetary Science Letters 50, 139-155.

Johnson, D.M., Hooper P.R., Conrey, R.M., 1999. XRF analysis of rocks and minerals for major and trace elements on a single low dilution Litetraborate fused bead. Advances in X-ray Analysis 41, 843-867.

Kemp, A.I.S., Hawkesworth, C. J., Paterson, B. A., Kinny, P.D., 2006. Episodic growth of the Gondwana supercontinent from hafnium and oxygen isotopes in zircon. Nature 439, 580-583. 
Kemp, A.I.S., Hawkesworth, C.J., Foster, G.L., Paterson, G.A., Woodhead, J.D., Hergt, J.M., Gray, C.M., Whitehouse, M.J., 2007. Magmatic and crustal differentiation history of granitic rocks from Hf-O isotopes in zircon. Science 315, 980-983.

Kosler, J. \& Sylvester, P.J. 2003. Present trends and the future of zircon in geochronology: laser ablation ICPMS. In: Hanchar, J.M. \& Hoskin, P.W.O. (eds). Zircon. Reviews in Mineralogy and Geochemistry 53, 243- 276.

Llambías, E.J., Sato, A.M., Ortiz Suárez, A., Prozzi, C., 1998. The granitoids of the Sierra de San Luis. In: Pankhurst, R.J., Rapela, C.W. (Eds.), The Proto-Andean margin of Gondwana: Geological Society of London, Special Publications 142, pp. 325-341.

López de Luchi, M.G., Rapalini, A.E., Siegesmund, S., Steenken, A. 2004. Application of magnetic fabrics to the emplacement and tectonic history of Devonian granitoids in central Argentina. In: Martín-Hernández, F., Lüneburg, F., Aubourg, C. y Jackson, M. (eds.) Magnetic fabric: methods and applications, Geological Society, London, Special Publications 238: 447-474.

Miller, C.F., McDowell, S.M., Mapes, R.W., 2003. Hot and cold granites? Implications of zircon saturation temperatures and preservation of inheritance. Geology 31, 529-532.

Miller, H., Söllner, F., 2005. The Famatina complex (NW-Argentina): back-docking of an island arc or terrane accretion? Early Palaeozoic geodynamics at the western Gondwana margin. In: Vaughan, A.P.M., Leat, P.T., Pankhurst, R.J. (Eds.), Terrane processes at the margins of Gondwana. Geological Society of London, Special Publication 246, 241-256.

Nelson, D.R. 1992. Isotopic characteristic of potassic rocks. Evidence for the involvement of subducted sediment in magma genesis. Lithos 28, 403-420.

Paces, J.B., and Miller, J.D. 1993, Precise U-Pb ages of Duluth Complex and related mafic intrusions, north- eastern Minnesota: geochronological insights to physical, petrogenetic, 
paleomagnetic, and tectonomagmatic processes associated with the $1.1 \mathrm{Ga}$ midcontinental rift system. Journal Geophysical Research 98, 13997-14013.

Pankhurst, R.J., Rapela, C.W., 1998. Theproto-AndeanmarginofGondwana: an introduction. The proto-Andean margin of Gondwana. In: Pankhurst, R.J., Rapela, C.W. (Eds.), Geological Society, London, Special Publications, vol. 142, pp. 1-9.

Pankhurst, R.J., Rapela, C.W., Fanning, C.M. 2000. Age and origin of coeval TTG, I-S-type granites in the Famatinian belt of NW Argentina. Transactions of the Royal Society of Edinburgh, Earth Sciences 91, 151-168.

Pankhurst, R.J., Rapela, C.W., Saavedra, J., Baldo, E.G., Dahlquist, J.A., Pascua, I., Fanning, C.M., 1998. The Famatinian arc in the central Sierras Pampeanas: an Early to Mid-Ordovician continental arc on the Gondwana margin. In: Pankhurst, R.J., Rapela, C.W. (Eds.), The ProtoAndean Margin of Gondwana. Geological Society of London, Special Publication 142, 343-367.

Parada, M.A., Nyström, J.O., Levi, B., 1999. Multiple sources for the Coastal Batholith of central Chile $\left(31^{\circ}-34^{\circ} \mathrm{S}\right)$ : geochemical and $\mathrm{Sr}-\mathrm{Nd}$ isotopic evidence and tectonics implications. Lithos 46, 505-521.

Pinotti, L., Coniglio, J., Esparza, A., D'Eramo, F., Llambías, E., 2002. Nearly circular plutons emplaced by stoping at shallow crustal levels, Cerro Áspero batholith, Sierras Pampeanas de Córdoba, Argentina. Journal of South American Earth Sciences 15, 251-265.

Pinotti, L., Tubía, J.M., D'Eramo, F., Vegas, N., Sato, A.M., Coniglio, J. y Aranguren, A., 2006. Structural interplay between plutons during the construction of a batholith (Cerro Aspero batholith, Sierras de Córdoba, Argentina). Journal of Structural Geology 28, 834-849.

Pitcher, W.S., 1979. The nature, ascent and emplacement of granitic magmas. Journal of the Geological Society, London 136, 627-662. 
Rapela, C.W., Pankhurst, R.J., Dahlquist, J.A., Baldo, E.G., Casquet, C., Galindo, C., 2008a.

Revisiting accretionary history and magma sources in the Southern Andes: Time variation of “typical Andean granites". International Symposium on Andean Geodynamics, $7^{\text {th }}$, Nice, France, extended abstracts, 427-430.

Rapela, C.W., Baldo, E.G., Pankhurst, R.J., Fanning, C.M., 2008b. The Devonian Achala batholith in the Sierras Pampeanas: F-rich aluminous A-type granites. San Carlos de Bariloche, Argentina. South American Symposium on Isotope Geology, $6^{\text {th }}$, CD-ROM, extended abstract 53.

Rapela, C.W., Pankhurst, R.J., Casquet, C., Baldo, E., Galindo, C., Fanning, C.M., Dahlquist, J.A., 2010. The Western Sierras Pampeanas: Protracted Grenville-age history (1330-1030 Ma) of intra-oceanic arcs, subduction-accretion at continental-edge and AMCG intraplate magmatism. Journal of South American Earth Sciences 29, 105-127.

Saavedra, J., Toselli, A., Rossi, J., Pellitero, E., Durand, F., 1998. The Early Palaeozoic magmatic record of the Famatina System: a review. In: Pankhurst, R.J., Rapela, C.W. (Eds.). The ProtoAndean Margin of Gondwana. Journal of the Geological Society of London, Special Publication $142,283-295$.

Scherer, E., Whitehouse, M.J., Münker, C., 2007. Zircon as a monitor of crustal growth. Elements 3, $19-24$.

Siebel, W. \& Chen, F. 2010. Zircon Hf isotope perspective on the origin of granitic rocks from eastern Bavaria, SW Bohemian Massif. International Journal of Earth Sciences 99, 993-1005.

Siegesmund, S., Steenken, A., López de Luchi, M.G., Wemmer, K., Hoffmann, A., Mosch, S., 2004. The Las Chacras-Potrerillos batholith (Pampean Ranges, Argentina): structural evidence, emplacement and timing of the intrusion. International Journal Earth Sciences 93, $23-43$.

Sims, J.P., Ireland, T.R., Camacho, A., Lyons, P., Pieters, P.E., Skirrow, R.G., Stuart-Smith, P.G. 1998. U-Pb, Th- $\mathrm{Pb}$ and Ar-Ar geochronology from the southern Sierras Pampeanas, Argentina: 
implications for the Palaeozoic tectonic evolution of the western Gondwana margin. In:

Pankhurst, R.J. \& Rapela, C.W. (eds) The Proto-Andean Margin of Gondwana. Geological Society, London, Special Publications 142, 259-281.

Söderlund, U., Patchett, P. J., Vervoort, J. D., and Isachsen, C. E., 2004. The 176Lu decay constant determined by Lu-Hf and U-Pb isotope systematics of Precambrian mafic intrusions. Earth and Planetary Science Letters 219, 311-324.

Spagnuolo, C.M., Rapalini, A.E., Astini, R.A., 2012. Assembly of Pampia to the SW Gondwana margin: a case of strike-slip docking? Gondwana Research 21, 406-421.

Steiger, R.H., Jäger, E., 1977. Subcommission of geochronology: convention on the use of decay constants in geo- and cosmochronology. Earth and Planetary Science Letters 36, 359-362.

Stuart-Smith, P.G., Miró, R., Sims, J.P., Pieters, P.E., Lyons, P., Camacho, A., Skirrow, R.G. and Black, L.P., 1999. Uranium-lead dating of felsic magmatic cycles in the southern Sierras Pampeanas, Argentina: implications for the tectonic development of the proto-Andean Gondwana margin, in: V.A., Ramos, J.D., Keppie (Eds.), Laurentia Gondwana connections before Pangea. Geological Society of America Special Publication 336, 87-114.

Tohver, E., Cawood, P.A., Rossello, E.A., Jourdan, F., 2012. Closure of the Clymene Ocean and formation of West Gondwana in the Cambrian: evidence from the Sierras Australes of the southernmost Rio de la Plata craton, Argentina. Gondwana Research 21, 394-405.

Vaughan, A.P.M., Pankhurst, R.J., 2008. Tectonic overview of the West Gondwana margin. Gondwana Research 13, 150-162.

Vervoort, J.D. \& Blichert-Toft, J., 1999. Evolution of the depleted mantle: Hf isotope evidence from juvenile rocks through time. Geochimica et Cosmochimica Acta 63, 533-556.

Wedepohl, K.H., 1995. The composition of the continental crust: Geochimica et Cosmochimica Acta $59,1217-1232$. 
Wilson, M. 1989. Igneous Petrogenesis, A Global Tectonic Approach. Unwin Hyman, London. pp. 466.

Willner, A.P., Gerdes, A., Massonne, H.-J., Schmidt, A., Sudo, M., Thomson, S.N., Vujovich, G., 2011. The geodynamics of collision of a microplate (Chilenia) in Devonian times deduced by the pressure-temperature-time evolution within part of a collisional belt (Guarguaraz complex,W-Argentina). Contributions toMineralogy and Petrology 162, 303-327.

Woodhead, J., Hergt, J., Shelley, M., Eggins, S., Kemp, R. 2004. Zircon Hf-isotope analysis with an excimer laser, depth profiling, ablation of complex geometries, and concomitant age estimation. Chemical Geology 209, 121-135. 
Fig. 3. Upper figure: Possible schematic geodynamic scenario for magma generation in the protoAndean margin of Gondwana at between $32^{\circ}$ and $26^{\circ} \mathrm{S}$ (see Fig. 1). Lower figure: Cartoon of the standard profile of the continental crust, modified from Wedepohl (1995). Generalized location for each magmatic event in Fig. 1: (a) Early-Middle Ordovician magma generation in a roll-back subduction setting, (b) Middle-Late Devonian and (c) Early Carboniferous magma generation in a dominant extensional regime with subsequent lithosphere thinning. The final emplacement of Achala granites is in dominant compressional regimen (see discussion in the the location of the studied Early-Middle Ordovician calc-alkaline granites and Middle-Late Devonian (Achala batholith) and Early Carboniferous A-type granites. Coupled in situ U-Pb ages and $\mathrm{Hf}$ isotope data for zircons and whole-rock $\mathrm{Sm} / \mathrm{Nd}$ data are included. Sources: $* \mathrm{U}-\mathrm{Pb}$ zircon SHRIMP (Pankhurst et al., 2000); †N.D. = Not determined; §U-Pb zircon SHRIMP (Alasino et al., 2012); **U-Pb zircon SHRIMP (Rapela et al. 2008b), otherwise data reported in this paper. Inset: Schematic geological map of South America showing the location of Sierras Pampeanas in Argentina.

Fig. 2. (a) The average Hf isotope composition of melt-precipitated zircons from samples of each suite as a function of whole-rock $\mathrm{Nd}$ isotope composition at the time of crystallization of the granitic rocks of Sierras Pampeanas. (b) $\varepsilon H f t$ values for magmatic zircons are plotted as a function of crystallization age. VEL-6017 defines two Hf compositions populations (see text). The depleted mantle evolution curve is from Kemp et al. (2006). 
text). The ascent of magmas during the Early Carboniferous (and probably during the MiddleLate Devonian) was facilitated by shear zones (see discussion in the text). The probable source for each setting is: (a) Early-Middle Ordovician: Mesoproterozoic continental crust $\left(\mathrm{T}_{\mathrm{DM}} \mathrm{Hf}=\right.$ 1.5-2.2 $\mathrm{Ga}$ and $\mathrm{T}_{\mathrm{DM}} \mathrm{Nd}=1.4-1.7 \mathrm{Ga}$ ), with no significant asthenospheric mantle contribution; (b) Middle-Late Devonian and (c) Early Carboniferous: mainly the Sierra de Córdoba basement and Ordovician granites, respectively. (b) and (c) support Mesoproterozoic continental crust source (see $\mathrm{T}_{\mathrm{DM}} \mathrm{Hf}$ and $\mathrm{T}_{\mathrm{DM}} \mathrm{Nd}$ in Table $3 \mathrm{a}, \mathrm{b}$ and 5) and a progressive mantle contribution (see discussion in the text). The presence of paleo-sediment in the source for settings (b) and (c) was included in agreement with the geotectonic scenario discussed by Alasino et al. (2012).

References for the three figures in Fig. 3a. 


\section{Figure}

Click here to download high resolution image

Fig. 1

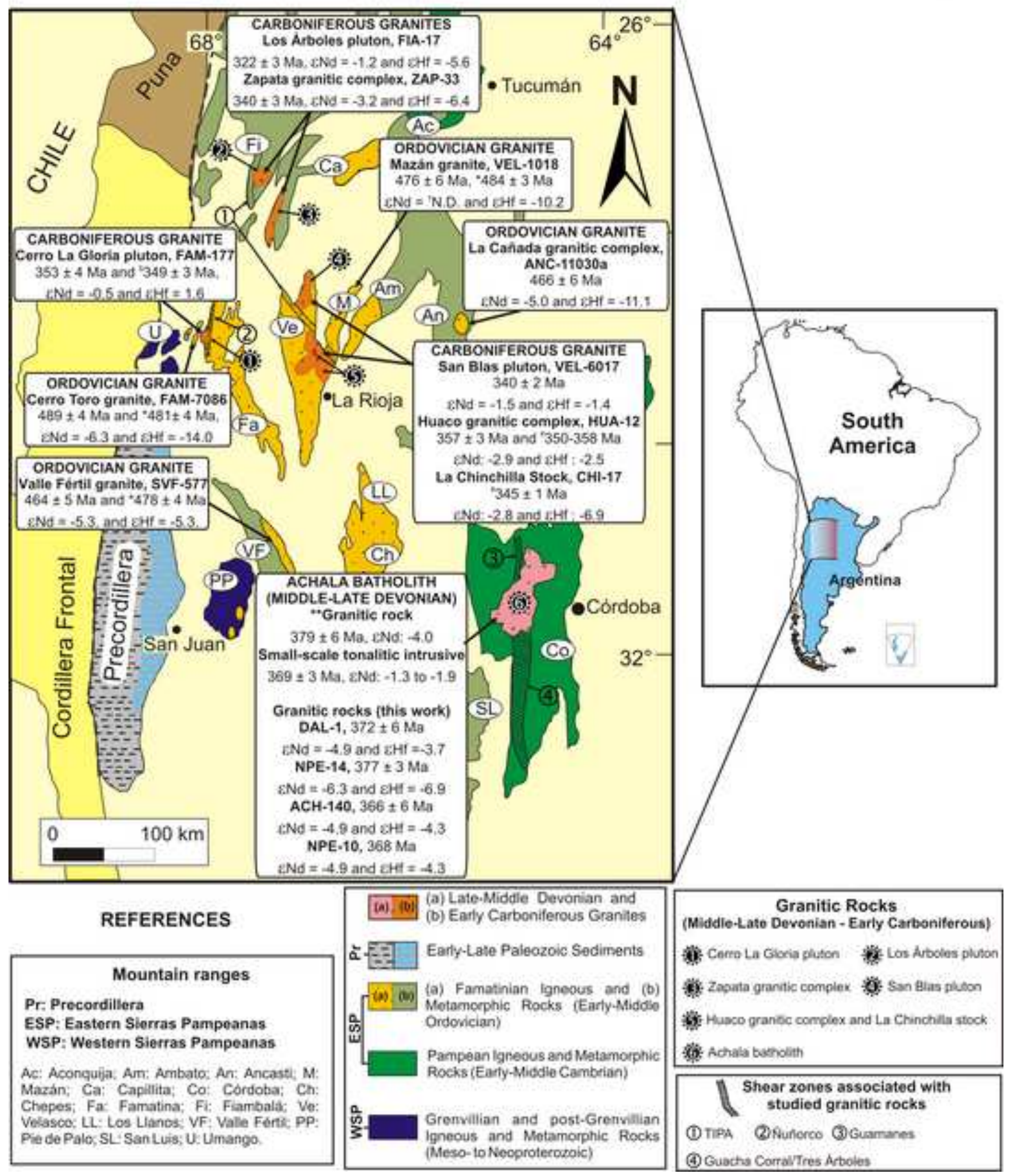




\section{Figure}

Click here to download high resolution image
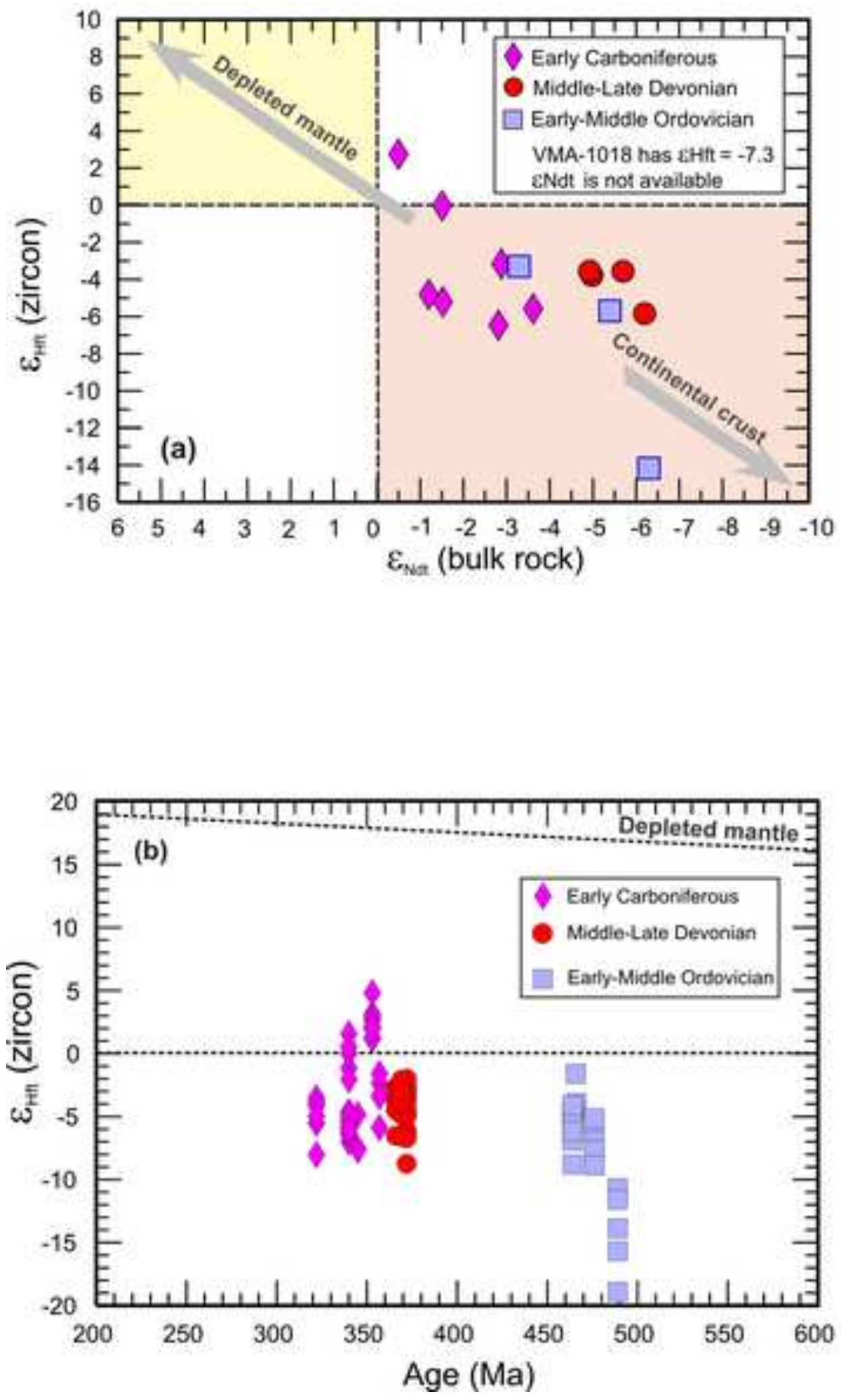


\section{Figure}

Click here to download high resolution image

(a)
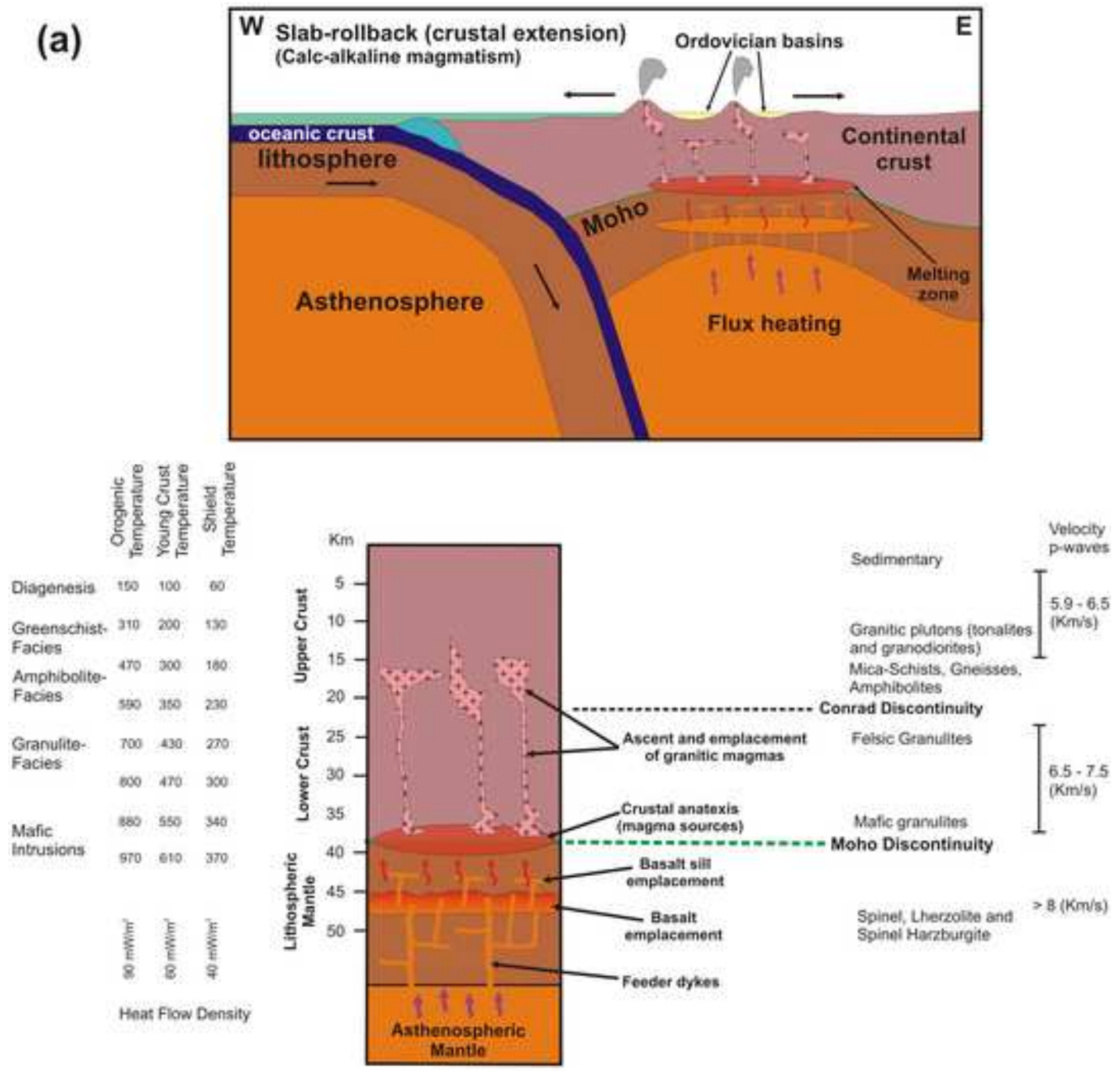

\section{Legend}

Paleo-sediments

if Adective heat influx

Granitic Plutons

Continental crust

Lithosphere

Heat influx from mantle 


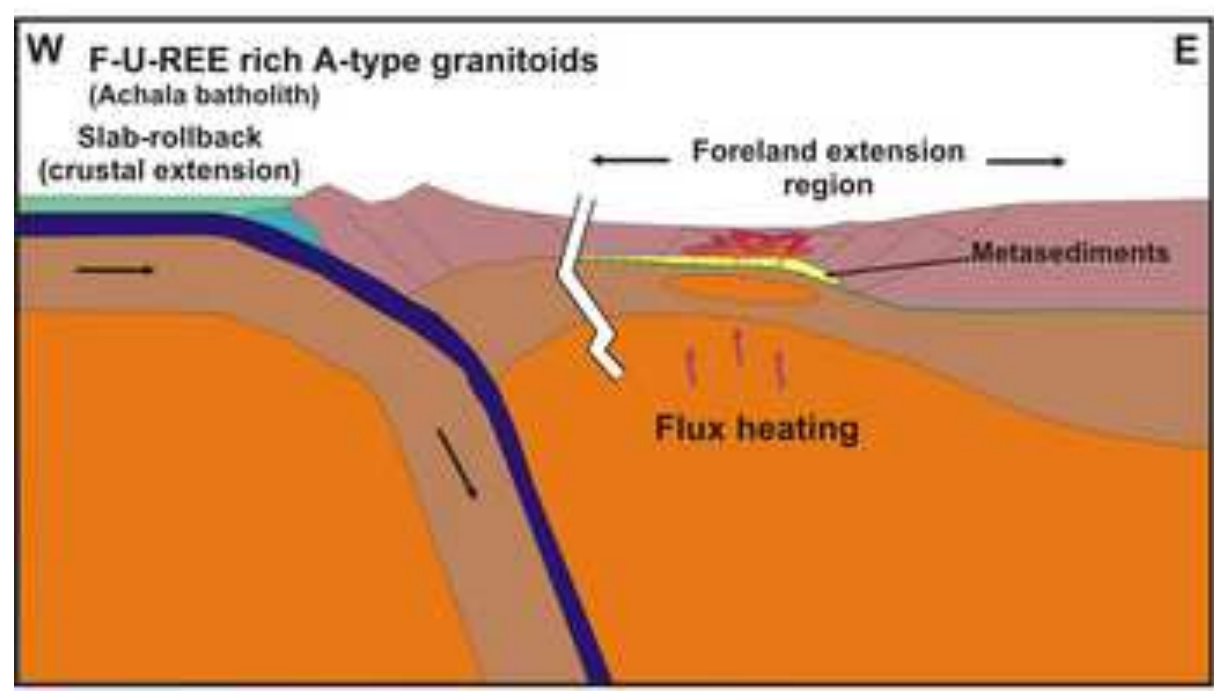

(b)
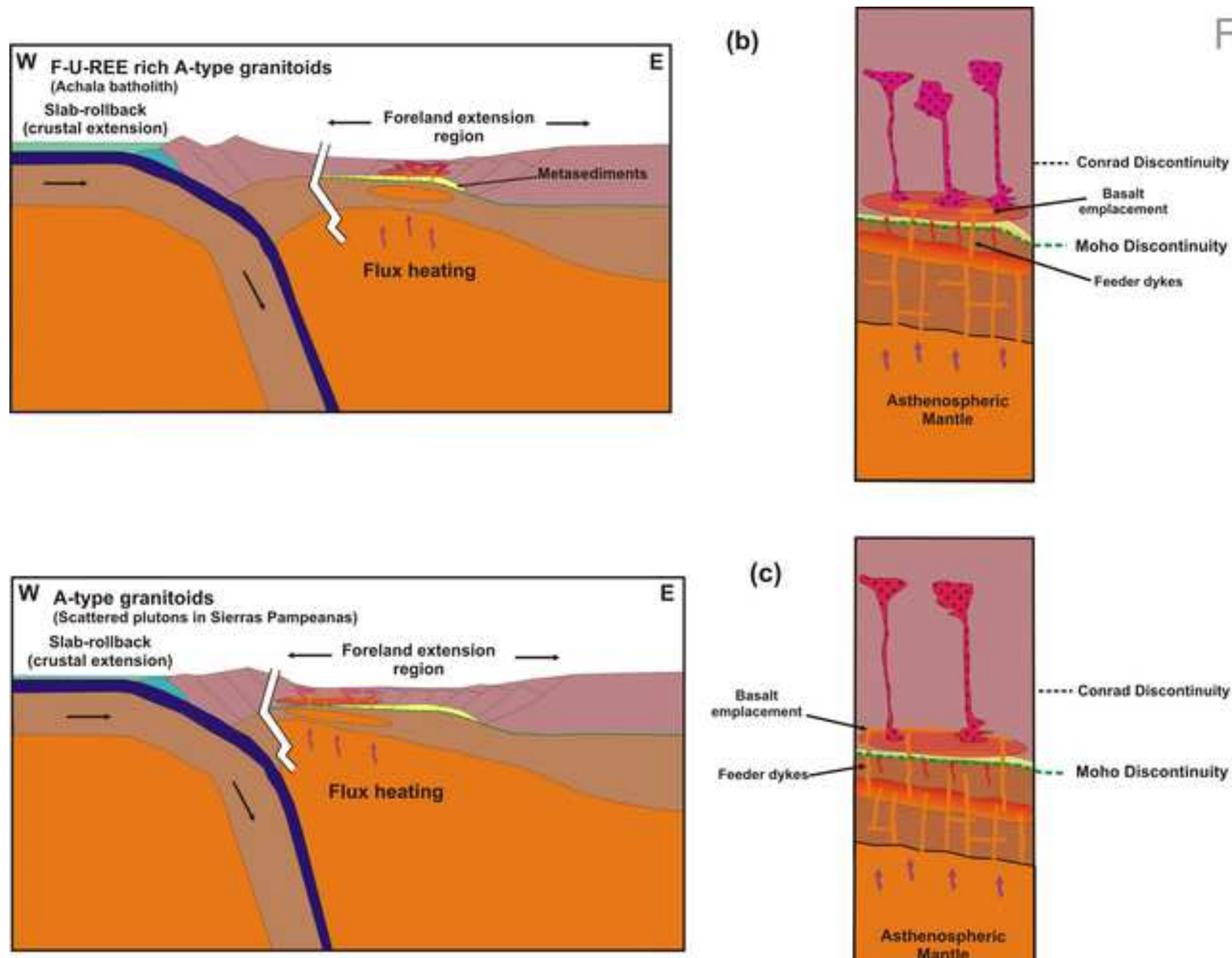

(c)

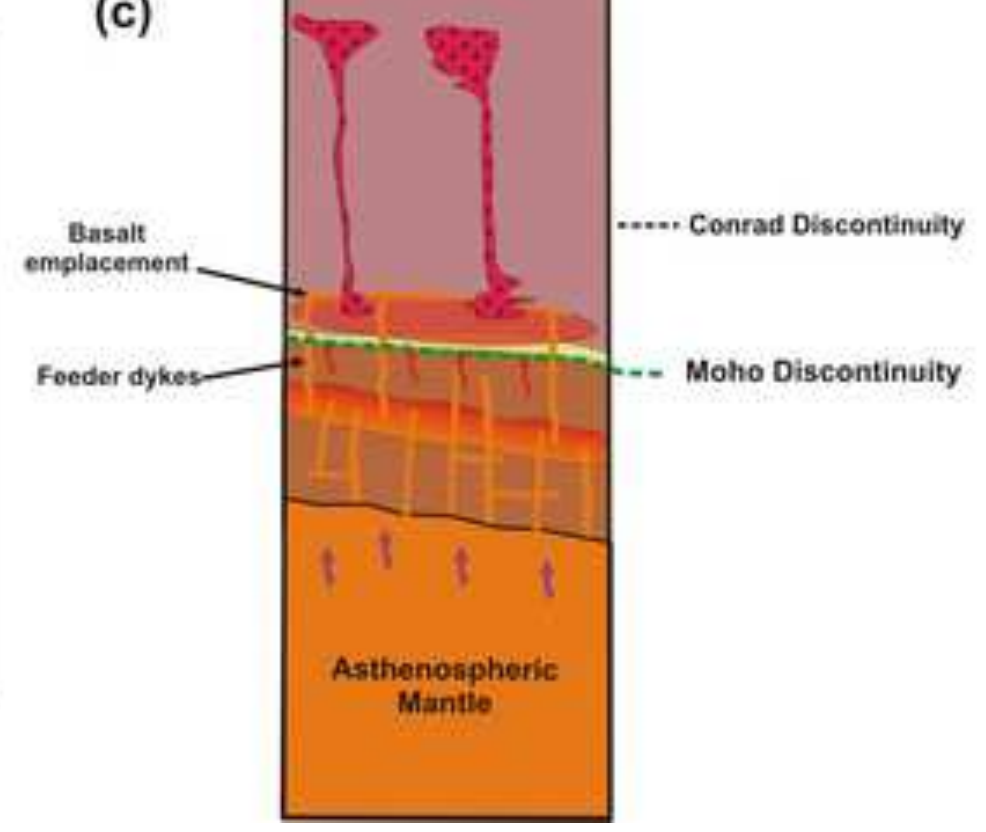


Table 1.

Integrated in situ U-Pb and $\mathrm{Hf}$ isotopes in zircon and whole-rock and isotopes data for the studied rocks (see Fig. 1)

\begin{tabular}{|c|c|c|c|c|c|c|c|c|}
\hline & U-Pb Ages* & U-Pb Ages ${ }^{\dagger}$ & $\varepsilon N d(t)^{\S}$ & $\varepsilon \mathrm{Hf}(\mathrm{t})$ & $\mathrm{T}_{\mathrm{DM}} \mathrm{Nd}$ & $\mathrm{T}_{\mathrm{DM}} \mathrm{Hf}$ & Latitude & Longitude \\
\hline \multicolumn{9}{|c|}{ Early-Middle Ordovician granitic rocks } \\
\hline \multicolumn{9}{|l|}{ Samples } \\
\hline SVF-577 & $464 \pm 5$ & $478 \pm 4$ & -5.4 & -5.7 & 1.6 & 1.7 & $30^{\circ} 39^{\prime} 28^{\prime \prime}$ & $67^{\circ} 36^{\prime} 17^{\prime \prime}$ \\
\hline VMA-1018 & $476 \pm 6$ & $484 \pm 3$ & N.D. ${ }^{\#}$ & -7.3 & N.D. & 1.8 & $28^{\circ} 43^{\prime} 31^{\prime \prime}$ & $66^{\circ} 34^{\prime} 31^{\prime \prime}$ \\
\hline FAM-7086 & $483 \pm 8$ & $481 \pm 4$ & -5.9 & -14.7 & 1.7 & 2.2 & $29^{\circ} 01^{\prime} 25^{\prime \prime}$ & $68^{\circ} 10^{\prime} 19^{\prime \prime}$ \\
\hline ANC-11030a & $466 \pm 6$ & N.D. & -4.9 & -3.3 & 1.6 & 1.5 & $28^{\circ} 57^{\prime} 56^{\prime \prime}$ & $65^{\circ} 25^{\prime} 08^{\prime \prime}$ \\
\hline \multicolumn{9}{|c|}{ Middle-Late Devonian granitic rocks } \\
\hline ACH-140 & $366 \pm 6$ & N.D. & -5.0 & -3.8 & 1.5 & 1.5 & $31^{\circ} 36^{\prime} 37^{\prime \prime}$ & $64^{\circ} 49^{\prime} 49^{\prime \prime}$ \\
\hline DAL-1 & $372 \pm 6$ & N.D. & -4.9 & -3.6 & 1.5 & 1.5 & $31^{\circ} 25^{\prime} 50^{\prime \prime}$ & $64^{\circ} 53^{\prime} 00^{\prime \prime}$ \\
\hline NPE-14 & $369 \pm 5$ & N.D. & -6.3 & -5.9 & 1.6 & 1.6 & $31^{\circ} 26^{\prime} 02^{\prime \prime}$ & $64^{\circ} 49^{\prime} 29^{\prime \prime}$ \\
\hline NPE-10 & $369 * *$ & N.D. & -5.7 & -3.8 & 1.6 & 1.5 & $31^{\circ} 25^{\prime} 46^{\prime \prime}$ & $64^{\circ} 49^{\prime} 50^{\prime \prime}$ \\
\hline \multicolumn{9}{|c|}{ Early Carboniferous granitic rocks } \\
\hline FIA-17 (Los Árboles pluton) & $322 \pm 3$ & & -1.6 & -5.0 & 1.2 & 1.6 & $27^{\circ} 44^{\prime} 31^{\prime \prime}$ & $67^{\circ} 30^{\prime} 04^{\prime \prime}$ \\
\hline VEL-6017 (San Blas pluton) & $340 \pm 2$ & $340 \pm 3$ & -1.6 & -5.2 and +0.5 & 1.2 & 1.6 and 1.3 & $28^{\circ} 27^{\prime} 14^{\prime \prime}$ & $67^{\circ} 06^{\prime} 02^{\prime \prime}$ \\
\hline ZAP-33 (Zapata granitic complex) & $332 \pm 3$ & & -3.6 & -5.8 & 1.4 & 1.6 & $27^{\circ} 53^{\prime} 18^{\prime \prime}$ & $67^{\circ} 21^{\prime} 15^{\prime \prime}$ \\
\hline FAM-177 (Cerro La Gloria pluton) & $353 \pm 4$ & $349 \pm 3^{\dagger \dagger}$ & -0.5 & 2.6 & 1.2 & 1.1 & $29^{\circ} 04^{\prime} 57.1^{\prime \prime}$ & $67^{\circ} 57^{\prime} 03.9^{\prime}$ \\
\hline HUA-12 (Huaco granitic complex) & $357 \pm 3$ & & -2.9 & -3.3 & 1.3 & 1.5 & $29^{\circ} 11^{\prime} 23^{\prime \prime}$ & $67^{\circ} 01^{\prime} 45^{\prime \prime}$ \\
\hline CHI-17 (La Chinchilla stock) & $345 \pm 1^{\S \S}$ & & -2.8 & -6.7 & 1.3 & 1.7 & $29^{\circ} 10^{\prime} 09^{\prime \prime}$ & $66^{\circ} 58^{\prime} 20^{\prime \prime}$ \\
\hline
\end{tabular}

NOTE: Compilation of data from Tables 3 and 4. VMA-1018 is not available for Sm/Nd determinations. VEL-6017 defines two Hf compositions populations (see Table 3).

*U-Pb zircon LA-ICP-MS, this work.

${ }^{\dagger}$ U-Pb zircon SHRIMP (Pankhurst et al., 2000; Dahlquist et al., 2008).

$\S_{\mathrm{t}}=473$, data from Table 4 .

\#N.D. = not determined.

**Average from ACH-140, DAL-1, and NPE-14. An U-Pb zircon age = 368 Ma was obtained by Dorais et al. (1997) for a rock such as NPE-10.

${ }^{\dagger} \mathrm{U}-\mathrm{Pb}$ zircon SHRIMP from Alasino et al. (2012).

${ }^{\S} \mathrm{U}-\mathrm{Pb}$ monazite LA-ICP-MS from Grosse et al. (2009). 
Table 2 Electronic Appendix 1.

LA-ICP-MS zircon results for the biotite-bearing tonalite of the Las Cañadas granitic complex.

\begin{tabular}{lccccccc} 
Grain & ${ }^{238} \mathrm{U}$ & $1 \sigma$ & ${ }^{207} \mathrm{~Pb}$ & $1 \sigma$ & ${ }^{206} \mathrm{~Pb} /{ }^{238} \mathrm{U}$ & $1 \sigma$ & ${ }^{207} \mathrm{~Pb} /{ }^{206} \mathrm{~Pb}$ \\
spot & ${ }^{206} \mathrm{~Pb}$ & & ${ }^{206} \mathrm{~Pb}$ & & age & $1 \sigma$ & age \\
\hline
\end{tabular}

\section{ANC 11030a (P)}

$\begin{array}{lllllllrr}\text { ANC-11030a_2a* } & 13.369 & 0.405 & 0.05630 & 0.00083 & 465 & 14 & 464 \\ \text { ANC-11030a_4b } & 13.680 & 0.415 & 0.06035 & 0.00075 & 455 & 13 & 616 \\ \text { ANC-11030a_5a* } & 13.530 & 0.411 & 0.05637 & 0.00071 & 460 & 13 & 467 \\ \text { ANC-11030a_7a } & 13.146 & 0.305 & 0.05803 & 0.00037 & 473 & 11 & 455 \\ \text { ANC-11030a_9a } & 12.805 & 0.292 & 0.05728 & 0.00083 & 485 & 11 & 531 & 28 \\ \text { ANC-11030a_16a } & 13.727 & 0.318 & 0.06206 & 0.00086 & 453 & 10 & 502 & 15 \\ \text { ANC-11030a_19a } & 13.658 & 0.252 & 0.05690 & 0.00081 & 456 & 8 & 676 & 31 \\ \text { ANC-11030a_24a* } & 13.215 & 0.279 & 0.05663 & 0.00076 & 470 & 10 & 488 & 29 \\ \text { ANC-11030a_25a* } & 13.438 & 0.203 & 0.05690 & 0.00079 & 463 & 7 & 477 & 31 \\ \text { ANC-11030a_27a } & 13.689 & 0.201 & 0.05690 & 0.00079 & 455 & 6 & 488 & 30 \\ \text { ANC-11030a_8a } & 13.339 & 0.269 & 0.05712 & 0.00047 & 467 & 11 & 496\end{array}$

\section{ANC 11030a (F)}

ANC-11030a 2a ANC-11030a_5a * ANC-11030a_7a* ANC-11030a_8a* ANC-11030a_9a

\subsection{4} 13.505

$0.206 \quad 0.05601$

0.209

$13.170 \quad 0.117$

0.05608

\subsection{2}

13.339

0.135

0.05638

0.00024

466

7

\section{3}

\subsection{4}

\section{$0.111 \quad 0.05836$}

0.00029

472

456

467

509

543

13.209

0.118

ANC-11030a_25a*

13.432

0.068

ANC-11030a_1a $\quad 6.640 \quad 0.106$

\subsection{7}

0.00030

466

\subsection{0}

0.00034

470

$$
479
$$

468

ANC-11030a_17a $\quad 11.720 \quad 0.082$

0.07075

0.00032

463

950

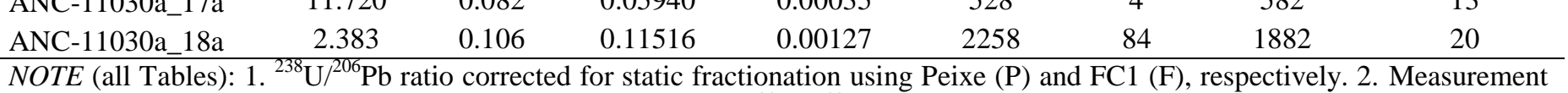

528

582

2258

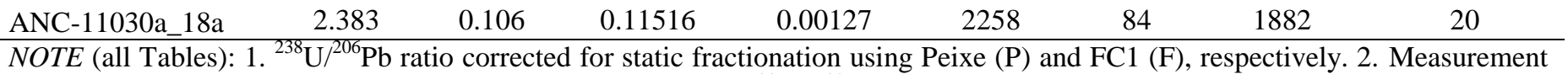

15

14

31

29

31

30

18 errors represent within-run standard error uncertainty only. $3{ }^{207} \mathrm{~Pb} /{ }^{206} \mathrm{~Pb}$ ratios corrected for static fractionation using Peixe (P) and FC1 (F), respectively. 4. Asterisk (*) indicates data points used for Concordia age calculation. 5. In red color the ages used in the calculations of epsilon $\mathrm{Nd}$ and $\mathrm{Hf}$, respectively. 6. Localization of samples in Fig. 1 and Table 1.

'Previous age (LA-ICP-MS U-Pb in zircon) reported by Dahlquist et al. (2012). 
Table 2

LA-ICP-MS Zircon results for the gabbro of the Sierra de Valle Fértil.

\begin{tabular}{|c|c|c|c|c|c|c|c|c|}
\hline $\begin{array}{l}\text { Grain } \\
\text { spot }\end{array}$ & $\begin{array}{c}{ }^{238} \mathrm{U} \\
{ }^{206} \mathrm{~Pb}\end{array}$ & $1 \sigma$ & $\begin{array}{l}{ }^{207} \mathrm{~Pb} \\
{ }^{206} \mathrm{~Pb} \\
\end{array}$ & $1 \sigma$ & $\begin{array}{c}{ }^{206} \mathrm{~Pb} /{ }^{238} \mathrm{U} \\
\text { age }\end{array}$ & $1 \sigma$ & $\begin{array}{c}{ }^{207} \mathrm{~Pb} /{ }^{206} \mathrm{~Pb} \\
\text { age }\end{array}$ & $1 \sigma$ \\
\hline \multicolumn{9}{|c|}{ SVF-577 (P) } \\
\hline Grain 1 & 13.355 & 0.200 & 0.05669 & 0.00078 & 465 & 7 & 474 & 21 \\
\hline Grain 4 & 13.309 & 0.196 & 0.05646 & 0.00070 & 467 & 7 & 489 & 19 \\
\hline Grain $5^{*}$ & 12.808 & 0.190 & 0.05712 & 0.00071 & 485 & 7 & 484 & 18 \\
\hline Grain $6^{*}$ & 12.798 & 0.188 & 0.05662 & 0.00071 & 485 & 7 & 487 & 18 \\
\hline Grain $7 *$ & 12.964 & 0.189 & 0.05577 & 0.00070 & 479 & 7 & 488 & 18 \\
\hline Grain $8^{*}$ & 13.642 & 0.230 & 0.05802 & 0.00092 & 456 & 7 & 890 & 33 \\
\hline Grain 9 & 13.409 & 0.187 & 0.05636 & 0.00074 & 464 & 6 & 464 & 21 \\
\hline Grain $10 *$ & 13.092 & 0.194 & 0.05934 & 0.00090 & 475 & 7 & 591 & 24 \\
\hline Grain $12 *$ & 13.363 & 0.371 & 0.05880 & 0.00062 & 465 & 12 & 948 & 39 \\
\hline Grain 13 & 13.666 & 0.353 & 0.05677 & 0.00044 & 455 & 11 & 466 & 15 \\
\hline Grain $14 *$ & 12.889 & 0.340 & 0.05614 & 0.00050 & 482 & 12 & 471 & 17 \\
\hline Grain 16 & 13.139 & 0.127 & 0.05598 & 0.00048 & 473 & 4 & 482 & 18 \\
\hline Grain $18 *$ & 13.389 & 0.132 & 0.05549 & 0.00060 & 464 & 4 & 452 & 23 \\
\hline Grain 19 & 13.281 & 0.117 & 0.05619 & 0.00041 & 468 & 4 & 487 & 15 \\
\hline Grain $20^{*}$ & 12.655 & 0.138 & 0.05807 & 0.00061 & 490 & 5 & 552 & 25 \\
\hline \multicolumn{9}{|c|}{ SVF-577 (F) } \\
\hline Grain 1 & 13.450 & 0.327 & 0.05670 & 0.00053 & 462 & 11 & 474 & 21 \\
\hline Grain 4 & 13.403 & 0.324 & 0.05647 & 0.00040 & 464 & 11 & 489 & 19 \\
\hline Grain $5^{*}$ & 12.898 & 0.313 & 0.05713 & 0.00041 & 481 & 11 & 484 & 18 \\
\hline Grain $6^{*}$ & 12.888 & 0.311 & 0.05662 & 0.00042 & 482 & 11 & 487 & 18 \\
\hline Grain $7 *$ & 13.055 & 0.314 & 0.05578 & 0.00042 & 476 & 11 & 488 & 18 \\
\hline Grain $8 *$ & 13.738 & 0.351 & 0.05803 & 0.00070 & 453 & 11 & 890 & 33 \\
\hline Grain $9 *$ & 13.503 & 0.320 & 0.05637 & 0.00047 & 461 & 11 & 464 & 21 \\
\hline Grain $10 *$ & 13.184 & 0.319 & 0.05935 & 0.00067 & 471 & 11 & 591 & 24 \\
\hline Grain $12 *$ & 13.029 & 0.920 & 0.05855 & 0.00062 & 477 & 32 & 948 & 39 \\
\hline Grain 13 & 13.325 & 0.932 & 0.05652 & 0.00043 & 466 & 31 & 466 & 15 \\
\hline Grain $14^{*}$ & 12.568 & 0.881 & 0.05590 & 0.00050 & 494 & 33 & 471 & 17 \\
\hline Grain $16^{*}$ & 12.962 & 0.682 & 0.05606 & 0.00045 & 479 & 24 & 482 & 18 \\
\hline Grain $18 *$ & 13.208 & 0.696 & 0.05557 & 0.00058 & 470 & 24 & 452 & 23 \\
\hline Grain $19 *$ & 13.101 & 0.688 & 0.05627 & 0.00038 & 474 & 24 & 487 & 15 \\
\hline Grain $20 *$ & 12.484 & 0.660 & 0.05815 & 0.00059 & 497 & 25 & 552 & 25 \\
\hline
\end{tabular}

Concordia Age $=468 \pm 2 \mathrm{Ma}$ ( $2 \sigma$, decay-const. errs included) MSWD (of concordance) $=0.040$, Probability (of concordance) $=0.84$

Concordia Age $=478 \pm 4 \mathrm{Ma}^{\dagger}$ MSWD $($ of concordance $)=0.60$

'Previous age (SHRIMP U-Pb in zircon) reported by Pankhurst et al. (2000). 
Table 2.

LA-ICP-MS zircon results for the cordierite-bearing monzogranite of the Sierra de Mazán.

\begin{tabular}{|c|c|c|c|c|c|c|c|c|}
\hline $\begin{array}{l}\text { Grain } \\
\text { spot }\end{array}$ & $\begin{array}{l}{ }^{238} \mathrm{U} \\
{ }^{206} \mathrm{~Pb} \\
\end{array}$ & $1 \sigma$ & $\begin{array}{l}{ }^{207} \mathrm{~Pb} \\
{ }^{206} \mathrm{~Pb} \\
\end{array}$ & $1 \sigma$ & $\begin{array}{c}{ }^{206} \mathrm{~Pb} /{ }^{238} \mathrm{U} \\
\text { age } \\
\end{array}$ & $1 \sigma$ & $\begin{array}{c}{ }^{207} \mathrm{~Pb} /{ }^{206} \mathrm{~Pb} \\
\text { age }\end{array}$ & $1 \sigma$ \\
\hline \multicolumn{9}{|c|}{ VMA-1018 (P) } \\
\hline Grain $2 *$ & 12.888 & 0.169 & 0.05663 & 0.00044 & 482 & 6 & 481 & 12 \\
\hline Grain 3 & 11.960 & 0.161 & 0.05841 & 0.00055 & 518 & 7 & 544 & 16 \\
\hline Grain 5 & 10.313 & 0.136 & 0.05789 & 0.00050 & 597 & 8 & 522 & 14 \\
\hline Grain 6 & 12.428 & 0.177 & 0.05661 & 0.00044 & 499 & 7 & 483 & 12 \\
\hline Grain 8 & 12.191 & 0.170 & 0.05747 & 0.00046 & 508 & 7 & 504 & 12 \\
\hline Grain $12 *$ & 13.265 & 0.256 & 0.05707 & 0.00054 & 469 & 9 & 517 & 17 \\
\hline Grain $13 *$ & 13.283 & 0.260 & 0.05614 & 0.00045 & 468 & 9 & 483 & 13 \\
\hline Grain 14 & 13.000 & 0.260 & 0.05865 & 0.00048 & 478 & 9 & 572 & 14 \\
\hline Grain 16 & 10.985 & 0.327 & 0.05844 & 0.00063 & 562 & 16 & 551 & 14 \\
\hline Grain $18 *$ & 12.945 & 0.377 & 0.05647 & 0.00060 & 480 & 13 & 482 & 14 \\
\hline Grain 19 & 13.689 & 0.398 & 0.05664 & 0.00055 & 455 & 13 & 480 & 10 \\
\hline Grain 20 & 11.788 & 0.352 & 0.06055 & 0.00067 & 525 & 15 & 595 & 11 \\
\hline Grain 21 & 11.548 & 0.367 & 0.05750 & 0.00058 & 535 & 16 & 510 & 12 \\
\hline Grain 23 & 13.573 & 0.400 & 0.05616 & 0.00056 & 458 & 13 & 470 & 11 \\
\hline Grain $24 *$ & 12.846 & 0.377 & 0.05687 & 0.00057 & 483 & 14 & 484 & 11 \\
\hline Grain 25 & 10.901 & 0.325 & 0.05718 & 0.00057 & 566 & 16 & 513 & 12 \\
\hline \multicolumn{9}{|c|}{ VMA-1018 (F) } \\
\hline Grain $2 *$ & 13.236 & 0.133 & 0.05667 & 0.00032 & 470 & 5 & 481 & 12 \\
\hline Grain 3 & 12.284 & 0.129 & 0.05845 & 0.00045 & 505 & 5 & 544 & 16 \\
\hline Grain 5 & 10.592 & 0.107 & 0.05793 & 0.00039 & 582 & 6 & 522 & 14 \\
\hline Grain 6 & 12.764 & 0.147 & 0.05665 & 0.00032 & 486 & 5 & 483 & 12 \\
\hline Grain 8 & 12.521 & 0.139 & 0.05751 & 0.00034 & 495 & 5 & 504 & 12 \\
\hline Grain 12 & 13.169 & 0.158 & 0.05701 & 0.00041 & 472 & 5 & 517 & 17 \\
\hline Grain $13^{*}$ & 13.186 & 0.166 & 0.05608 & 0.00030 & 471 & 6 & 483 & 13 \\
\hline Grain 14 & 12.905 & 0.170 & 0.05859 & 0.00033 & 481 & 6 & 572 & 14 \\
\hline Grain 16 & 11.266 & 0.217 & 0.05837 & 0.00036 & 548 & 10 & 551 & 14 \\
\hline Grain $18^{*}$ & 13.277 & 0.241 & 0.05640 & 0.00033 & 468 & 8 & 482 & 14 \\
\hline Grain 19 & 14.039 & 0.254 & 0.05657 & 0.00023 & 444 & 8 & 480 & 10 \\
\hline Grain 20 & 12.090 & 0.236 & 0.06047 & 0.00040 & 512 & 10 & 595 & 11 \\
\hline Grain 21 & 11.843 & 0.266 & 0.05742 & 0.00027 & 523 & 11 & 510 & 12 \\
\hline Grain 23 & 13.920 & 0.261 & 0.05609 & 0.00026 & 447 & 8 & 470 & 11 \\
\hline Grain $24 *$ & 13.175 & 0.246 & 0.05680 & 0.00027 & 472 & 8 & 484 & 11 \\
\hline Grain 25 & 11.180 & 0.216 & 0.05711 & 0.00027 & 552 & 10 & 513 & 12 \\
\hline
\end{tabular}

Concordia Age $=476 \pm 6 \mathrm{Ma}$ ( $95 \%$ confidence, decay-const. errs included)

MSWD (of concordance) $=0.0095$,

Probability (of concordance) $=0.92$
Concordia Age $=484 \pm 3 \mathrm{Ma}^{\dagger}$ MSWD (of concordance) $=0.61$

\footnotetext{
'Previous age (SHRIMP U-Pb in zircon) reported by Pankhurst et al. (2000).
} 
Table 2.

LA-ICP-MS zircon results for the biotite-bearing tonalite of the Cerro Toro (Western flank of the Sierra de Famatina)

\begin{tabular}{|c|c|c|c|c|c|c|c|c|}
\hline $\begin{array}{l}\text { Grain } \\
\text { spot }\end{array}$ & $\begin{array}{l}{ }^{238} \mathrm{U} \\
{ }^{206} \mathrm{~Pb}\end{array}$ & $1 \sigma$ & $\begin{array}{l}{ }^{207} \mathrm{~Pb} \\
{ }^{206} \mathrm{~Pb}\end{array}$ & $1 \sigma$ & $\begin{array}{c}{ }^{206} \mathrm{~Pb} /{ }^{238} \mathrm{U} \\
\text { age }\end{array}$ & $1 \sigma$ & $\begin{array}{c}{ }^{207} \mathrm{~Pb} /{ }^{206} \mathrm{~Pb} \\
\text { age }\end{array}$ & $1 \sigma$ \\
\hline \multicolumn{9}{|l|}{$\begin{array}{l}\text { FAM-7086 } \\
\text { (P) }\end{array}$} \\
\hline Grain 1 & 13.304 & 0.231 & 0.05486 & 0.00060 & 467 & 8 & 460 & 20 \\
\hline Grain $2 *$ & 12.557 & 0.224 & 0.05716 & 0.00059 & 494 & 8 & 500 & 15 \\
\hline Grain 3 & 12.896 & 0.212 & 0.05592 & 0.00052 & 481 & 8 & 478 & 11 \\
\hline Grain $4^{*}$ & 12.671 & 0.247 & 0.05660 & 0.00054 & 490 & 9 & 487 & 12 \\
\hline Grain $7 *$ & 12.644 & 0.200 & 0.05736 & 0.00055 & 491 & 7 & 732 & 63 \\
\hline Grain 8 & 12.789 & 0.323 & 0.05898 & 0.00082 & 485 & 12 & 1250 & 171 \\
\hline Grain 9 & 13.428 & 0.244 & 0.05636 & 0.00066 & 463 & 8 & 538 & 19 \\
\hline Grain $10^{*}$ & 12.884 & 0.193 & 0.05657 & 0.00052 & 482 & 7 & 476 & 11 \\
\hline Grain 13 & 13.486 & 0.289 & 0.05697 & 0.00058 & 461 & 10 & 478 & 15 \\
\hline Grain 15 & 12.648 & 0.271 & 0.05858 & 0.00056 & 491 & 10 & 565 & 13 \\
\hline Grain 18 & 13.255 & 0.315 & 0.05728 & 0.00062 & 469 & 11 & 522 & 17 \\
\hline Grain $19 *$ & 12.625 & 0.301 & 0.05707 & 0.00054 & 491 & 11 & 563 & 17 \\
\hline
\end{tabular}

\section{FAM-7086}

\begin{tabular}{lcccccccc} 
(F) & & & & & & \\
Grain 1 & 13.304 & 0.231 & 0.05486 & 0.00060 & 467 & 8 & 460 & 20 \\
Grain 2* & 12.557 & 0.224 & 0.05716 & 0.00059 & 494 & 8 & 500 & 15 \\
Grain 3 & 12.896 & 0.212 & 0.05592 & 0.00052 & 481 & 8 & 478 & 11 \\
Grain 4* & 12.671 & 0.247 & 0.05660 & 0.00054 & 490 & 9 & 487 & 12 \\
Grain 7 & 12.644 & 0.200 & 0.05736 & 0.00055 & 491 & 7 & 732 & 63 \\
Grain 8 & 12.789 & 0.323 & 0.05898 & 0.00082 & 485 & 12 & 1250 & 171 \\
Grain 9 & 13.428 & 0.244 & 0.05636 & 0.00066 & 463 & 8 & 538 & 19 \\
Grain 10 & 12.884 & 0.193 & 0.05657 & 0.00052 & 482 & 7 & 476 & 11 \\
Grain 13 & 13.486 & 0.289 & 0.05697 & 0.00058 & 461 & 10 & 478 & 15 \\
Grain 15 & 12.648 & 0.271 & 0.05858 & 0.00056 & 491 & 10 & 565 & 13 \\
Grain 18 & 13.255 & 0.315 & 0.05728 & 0.00062 & 469 & 11 & 522 & 17 \\
Grain 19* & 12.625 & 0.301 & 0.05707 & 0.00054 & 491 & 11 & 563 & 17 \\
\hline
\end{tabular}

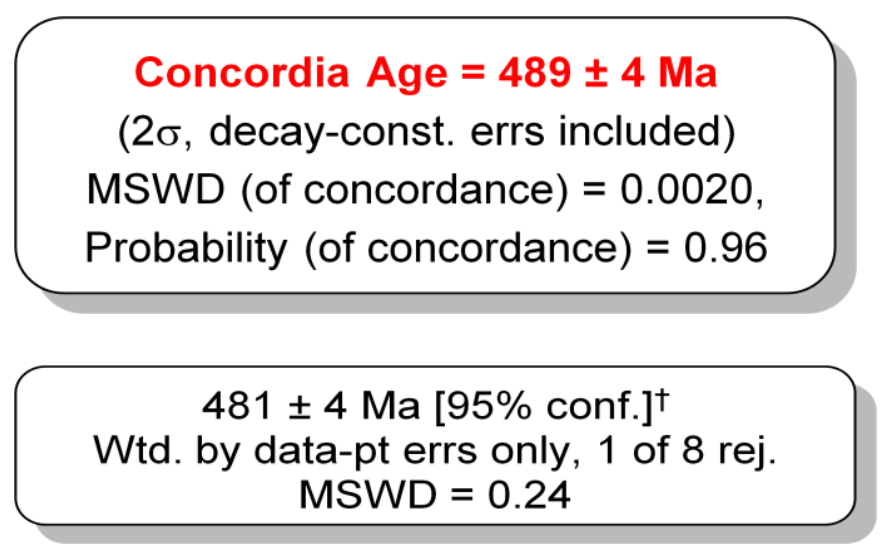

${ }^{\dagger}$ Previous age (SHRIMP U-Pb in zircon) reported by Dahlquist et al. (2008).

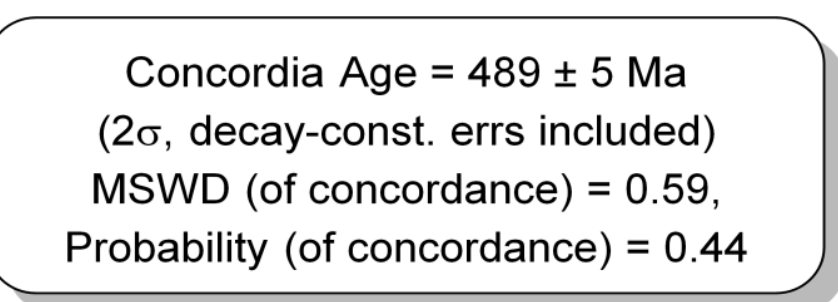


Table 2.

LA-ICP-MS zircon results for the monzogranite NPE-14 of the Achala batholith

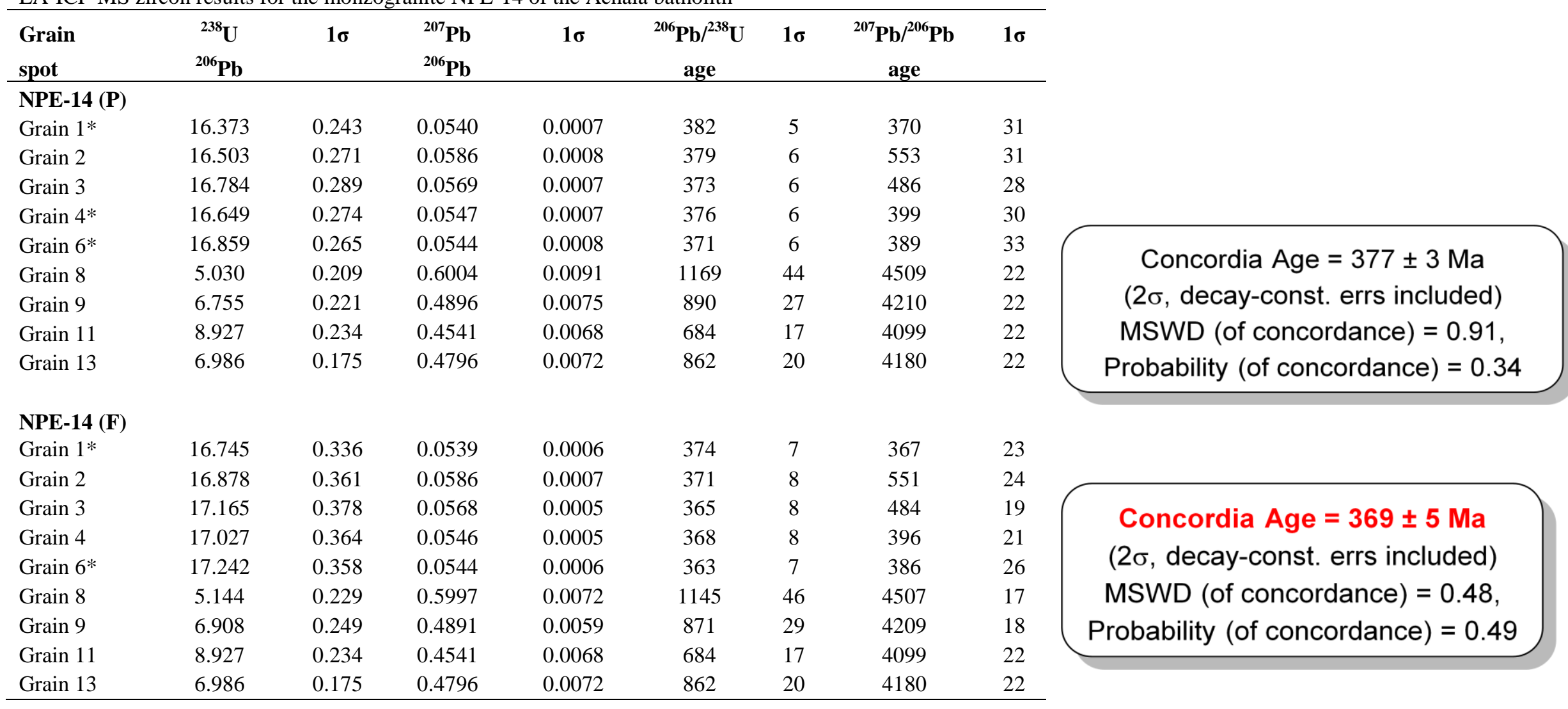


Table 2.

LA-ICP-MS zircon results for the monzogranite DAL-1 of the Achala batholith

\begin{tabular}{|c|c|c|c|c|c|c|c|c|c|}
\hline $\begin{array}{l}\text { Grain } \\
\text { spot }\end{array}$ & $\begin{array}{c}{ }^{238} \mathrm{U} \\
{ }^{206} \mathrm{~Pb} \\
\end{array}$ & $1 \sigma$ & $\begin{array}{l}{ }^{207} \mathrm{~Pb} \\
{ }^{206} \mathrm{~Pb} \\
\end{array}$ & $1 \sigma$ & $\begin{array}{c}{ }^{206} \mathrm{~Pb} /{ }^{238} \mathrm{U} \\
\text { age }\end{array}$ & $1 \sigma$ & $\begin{array}{c}{ }^{207} \mathrm{~Pb} /{ }^{206} \mathrm{~Pb} \\
\text { age }\end{array}$ & $1 \sigma$ & \\
\hline \multicolumn{10}{|l|}{ DAL-1 (P) } \\
\hline Grain 1 & 18.059 & 0.436 & 0.0587 & 0.0010 & 347 & 8 & 557 & 36 & \\
\hline Grain 3 & 15.957 & 0.376 & 0.0539 & 0.0008 & 392 & 9 & 367 & 34 & \\
\hline Grain 4 & 18.776 & 0.464 & 0.0596 & 0.0009 & 334 & 8 & 590 & 32 & \\
\hline Grain 5 & 15.974 & 0.388 & 0.0582 & 0.0009 & 391 & 9 & 538 & 33 & \\
\hline Grain 6 & 15.457 & 0.363 & 0.0549 & 0.0008 & 404 & 9 & 408 & 33 & \\
\hline Grain 7 & 14.948 & 0.369 & 0.0541 & 0.0008 & 417 & 10 & 373 & 35 & \\
\hline Grain 8 & 16.172 & 0.402 & 0.0596 & 0.0009 & 387 & 9 & 589 & 33 & \\
\hline Grain 9 & 16.178 & 0.379 & 0.0591 & 0.0009 & 387 & 9 & 570 & 33 & \\
\hline Grain 10 & 16.712 & 0.406 & 0.0547 & 0.0008 & 375 & 9 & 400 & 33 & \\
\hline Grain $11^{*}$ & 16.248 & 0.371 & 0.0548 & 0.0006 & 385 & 9 & 405 & 23 & Concordia Age $=387 \pm 5 \mathrm{Ma}$ \\
\hline Grain 13 & 15.712 & 0.348 & 0.0560 & 0.0006 & 398 & 9 & 452 & 22 & ( $2 \sigma$, decay-const. errs included) \\
\hline Grain $14 *$ & 16.061 & 0.346 & 0.0541 & 0.0006 & 389 & 8 & 374 & 23 & MSWD (of concordance) $=0.071$ \\
\hline Grain 18 & 15.774 & 0.362 & 0.0537 & 0.0005 & 396 & 9 & 358 & 22 & Probability (of concordance) $=0.79$ \\
\hline Grain $19 *$ & 16.184 & 0.376 & 0.0544 & 0.0006 & 386 & 9 & 389 & 24 & \\
\hline Grain 20 & 15.345 & 0.361 & 0.0553 & 0.0006 & 407 & 9 & 422 & 25 & \\
\hline \multicolumn{10}{|l|}{ DAL-1 (F) } \\
\hline Grain 1 & 18.727 & 0.624 & 0.0584 & 0.0006 & 347 & 8 & 557 & 36 & \\
\hline Grain 3 & 16.547 & 0.544 & 0.0536 & 0.0004 & 392 & 9 & 367 & 34 & \\
\hline Grain 4 & 19.471 & 0.657 & 0.0593 & 0.0004 & 334 & 8 & 590 & 32 & \\
\hline Grain 5 & 16.564 & 0.554 & 0.0579 & 0.0005 & 391 & 9 & 538 & 33 & \\
\hline Grain 6 & 16.028 & 0.526 & 0.0546 & 0.0004 & 404 & 9 & 408 & 33 & \\
\hline Grain 7 & 15.501 & 0.523 & 0.0537 & 0.0005 & 417 & 10 & 373 & 35 & \\
\hline Grain 8 & 16.770 & 0.569 & 0.0592 & 0.0005 & 387 & 9 & 589 & 33 & \\
\hline Grain 9 & 16.776 & 0.550 & 0.0587 & 0.0005 & 387 & 9 & 570 & 33 & \\
\hline Grain 10 & 17.330 & 0.579 & 0.0544 & 0.0004 & 375 & 9 & 400 & 33 & \\
\hline Grain 11 & 17.037 & 0.478 & 0.0547 & 0.0004 & 385 & 9 & 405 & 23 & \\
\hline Grain 13 & 16.475 & 0.451 & 0.0559 & 0.0004 & 398 & 9 & 452 & 22 & (2) decav-conct erre included) \\
\hline Grain $14 *$ & 16.841 & 0.453 & 0.0540 & 0.0004 & 389 & 8 & 374 & 23 & $(2 \sigma$, decay-const. errs included) \\
\hline Grain 18 & 16.540 & 0.465 & 0.0536 & 0.0004 & 396 & 9 & 358 & 22 & MSWD (of concordance) = 0.91, \\
\hline Grain $19^{*}$ & 16.970 & 0.481 & 0.0544 & 0.0004 & 386 & 9 & 389 & 24 & Probability (of concordance) $=0.34$ \\
\hline Grain 20 & 16.090 & 0.461 & 0.0552 & 0.0005 & 407 & 9 & 422 & 25 & \\
\hline
\end{tabular}

This age is more consistent with that previously reported for granitic rocks of the Achala batholith (e.g., Dorais et al., 1997; Rapela et al., 2008b). 
Table 2.

LA-ICP-MS zircon results for the monzogranite ACH-140 of the Achala batholith

\begin{tabular}{|c|c|c|c|c|c|c|c|c|c|}
\hline $\begin{array}{l}\text { Grain } \\
\text { spot }\end{array}$ & $\begin{array}{c}{ }^{238} \mathrm{U} \\
{ }^{206} \mathrm{~Pb} \\
\end{array}$ & $1 \sigma$ & $\begin{array}{l}{ }^{207} \mathrm{~Pb} \\
{ }^{206} \mathrm{~Pb}\end{array}$ & $1 \sigma$ & $\begin{array}{c}{ }^{206} \mathrm{~Pb} /{ }^{238} \mathrm{U} \\
\text { age }\end{array}$ & $1 \sigma$ & $\begin{array}{c}{ }^{207} \mathrm{~Pb} /{ }^{206} \mathrm{~Pb} \\
\text { age }\end{array}$ & $1 \sigma$ & \\
\hline ACH-140 (P) & & & & & & & & & \\
\hline Grain 1 & 16.590 & 0.161 & 0.056 & 0.001 & 377 & 4 & 469 & 22 & \\
\hline Grain 2 & 17.487 & 0.180 & 0.056 & 0.001 & 358 & 4 & 437 & 23 & \\
\hline Grain $3 *$ & 16.797 & 0.157 & 0.054 & 0.001 & 373 & 3 & 392 & 21 & \\
\hline Grain $7 *$ & 16.799 & 0.170 & 0.054 & 0.001 & 373 & 4 & 383 & 24 & \\
\hline Grain 8 & 16.124 & 0.165 & 0.055 & 0.001 & 388 & 4 & 430 & 21 & \\
\hline Grain 10 & 17.345 & 0.172 & 0.057 & 0.001 & 361 & 3 & 496 & 22 & \\
\hline Grain 11 & 16.088 & 0.165 & 0.055 & 0.001 & 389 & 4 & 403 & 22 & \\
\hline Grain 13 & 17.885 & 0.178 & 0.074 & 0.001 & 351 & 3 & 1031 & 20 & Concordia Age $=373 \pm 3 \mathrm{Ma}$ \\
\hline Grain 14 & 16.340 & 0.177 & 0.055 & 0.001 & 383 & 4 & 408 & 24 & \\
\hline Grain 16 & 16.403 & 0.156 & 0.055 & 0.001 & 381 & 4 & 423 & 22 & 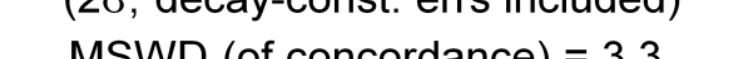 \\
\hline Grain 17 & 17.282 & 0.170 & 0.055 & 0.001 & 363 & 3 & 412 & 21 & MSWD (of concordance) = 3.3, \\
\hline Grain 18 & 16.437 & 0.167 & 0.055 & 0.001 & 381 & 4 & 425 & 23 & Probability (of concordance) $=0.069$ \\
\hline Grain 20 & 16.544 & 0.190 & 0.055 & 0.001 & 378 & 4 & 424 & 23 & \\
\hline \multicolumn{10}{|l|}{ ACH-140 (F) } \\
\hline Grain 1 & 16.936 & 0.392 & 0.0560 & 0.0007 & 370 & 8 & 454 & 27 & \\
\hline Grain 2 & 17.851 & 0.418 & 0.0552 & 0.0007 & 351 & 8 & 422 & 28 & \\
\hline Grain $3 *$ & 17.148 & 0.394 & 0.0541 & 0.0006 & 365 & 8 & 376 & 26 & \\
\hline Grain $7 *$ & 17.149 & 0.400 & 0.0539 & 0.0007 & 365 & 8 & 368 & 28 & \\
\hline Grain 8 & 16.461 & 0.385 & 0.0551 & 0.0006 & 380 & 9 & 415 & 26 & \\
\hline Grain 10 & 17.707 & 0.411 & 0.0567 & 0.0007 & 354 & 8 & 480 & 27 & \\
\hline Grain 11 & 16.552 & 0.224 & 0.0544 & 0.0004 & 378 & 5 & 387 & 15 & \\
\hline Grain 13 & 18.402 & 0.243 & 0.0731 & 0.0005 & 341 & 4 & 1017 & 14 & Concordia Age $=366 \pm 6 \mathrm{Ma}$ \\
\hline Grain 14 & 16.812 & 0.235 & 0.0545 & 0.0004 & 372 & 5 & 392 & 17 & ( $2 \sigma$, decay-const. errs included) \\
\hline Grain 16 & 16.877 & 0.218 & 0.0549 & 0.0003 & 371 & 5 & 407 & 14 & MSWD (of concordance) $=0.43$ \\
\hline Grain 17 & 17.781 & 0.234 & 0.0546 & 0.0003 & 353 & 5 & 395 & 13 & Probability (of concordance) $=0.51$ \\
\hline Grain 18 & 16.912 & 0.227 & 0.0549 & 0.0004 & 370 & 5 & 409 & 16 & Probability (of concordance) $=0.51$ \\
\hline Grain 20 & 17.022 & 0.247 & 0.0549 & 0.0004 & 368 & 5 & 407 & 16 & \\
\hline
\end{tabular}


Table 2.

LA-ICP-MS zircon results for the Los Árboles pluton (Sierra de Fiambalá)

\begin{tabular}{|c|c|c|c|c|c|c|c|c|c|}
\hline $\begin{array}{l}\text { Grain } \\
\text { spot }\end{array}$ & $\begin{array}{c}{ }^{238} \mathrm{U} \\
{ }^{206} \mathrm{~Pb}\end{array}$ & $1 \sigma$ & $\begin{array}{l}{ }^{207} \mathrm{~Pb} \\
{ }^{206} \mathrm{~Pb}\end{array}$ & $1 \sigma$ & $\begin{array}{c}{ }^{206} \mathrm{~Pb} /{ }^{238} \mathrm{U} \\
\text { age }\end{array}$ & $1 \sigma$ & $\begin{array}{c}{ }^{207} \mathrm{~Pb} /{ }^{206} \mathrm{~Pb} \\
\text { age }\end{array}$ & $1 \sigma$ & \\
\hline \multicolumn{10}{|l|}{ FIA-17 (P) } \\
\hline Grain 1a & 19.531 & 0.249 & 0.05369 & 0.00062 & 322 & 4 & 358 & 26 & \multirow{10}{*}{$\begin{array}{c}\text { Concordia Age }=325 \pm 10 \mathrm{Ma} \\
\begin{array}{r}(95 \% \text { confidence, decay-const. errs } \\
\text { included) }\end{array} \\
\text { MSWD (of concordance) }=11.0, \\
\text { Probability (of concordance) }=0.001\end{array}$} \\
\hline Grain $1 b^{*}$ & 19.433 & 0.266 & 0.05381 & 0.00062 & 323 & 4 & 363 & 26 & \\
\hline Grain $3 a^{*}$ & 19.320 & 0.287 & 0.05352 & 0.00066 & 325 & 5 & 351 & 28 & \\
\hline Grain 4a & 19.923 & 0.247 & 0.05361 & 0.00061 & 316 & 4 & 355 & 25 & \\
\hline Grain $7 a^{*}$ & 19.969 & 0.260 & 0.05354 & 0.00067 & 315 & 4 & 352 & 28 & \\
\hline Grain $7 b$ & 19.694 & 0.253 & 0.05253 & 0.00068 & 319 & 4 & 309 & 29 & \\
\hline Grain 8a & 19.898 & 0.216 & 0.05650 & 0.00069 & 316 & 3 & 472 & 27 & \\
\hline Grain 12a & 18.866 & 0.195 & 0.05526 & 0.00065 & 333 & 3 & 423 & 26 & \\
\hline Grain $18 \mathrm{a}$ & 19.139 & 0.205 & 0.05459 & 0.00061 & 328 & 3 & 395 & 25 & \\
\hline Grain 19a & 19.931 & 0.225 & 0.05520 & 0.00062 & 316 & 3 & 421 & 25 & \\
\hline \multicolumn{10}{|l|}{ FIA-17 (F) } \\
\hline Grain $1 \mathrm{a}^{*}$ & 19.403 & 0.227 & 0.05295 & 0.00035 & 324 & 4 & 326 & 15 & \multirow{10}{*}{$\begin{array}{c}\text { Concordia Age }=322 \pm 3 \mathrm{Ma} \\
(95 \% \text { confidence, decay-const. errs } \\
\text { included) } \\
\text { MSWD (of concordance) }=0.45, \\
\text { Probability (of concordance) }=0.50\end{array}$} \\
\hline Grain $1 b^{*}$ & 19.305 & 0.245 & 0.05306 & 0.00034 & 326 & 4 & 331 & 14 & \\
\hline Grain $3 a^{*}$ & 19.193 & 0.267 & 0.05278 & 0.00042 & 327 & 4 & 320 & 18 & \\
\hline Grain 4a* & 19.792 & 0.224 & 0.05287 & 0.00033 & 318 & 4 & 323 & 14 & \\
\hline Grain $7 a^{*}$ & 19.838 & 0.238 & 0.05280 & 0.00043 & 317 & 4 & 320 & 18 & \\
\hline Grain 7b & 19.565 & 0.231 & 0.05181 & 0.00046 & 321 & 4 & 277 & 20 & \\
\hline Grain 8a & 19.723 & 0.218 & 0.05604 & 0.00029 & 319 & 3 & 454 & 12 & \\
\hline Grain 12a & 18.700 & 0.198 & 0.05480 & 0.00021 & 336 & 3 & 404 & 9 & \\
\hline Grain 18a & 18.856 & 0.111 & 0.05430 & 0.00036 & 333 & 2 & 384 & 15 & \\
\hline Grain 19a & 19.637 & 0.135 & 0.05492 & 0.00037 & 320 & 2 & 409 & 15 & \\
\hline
\end{tabular}


Table 2.

LA-ICP-MS zircon results for the Zapata granitic complex (Sierra de Zapata)

\begin{tabular}{|c|c|c|c|c|c|c|c|c|c|}
\hline $\begin{array}{l}\text { Grain } \\
\text { spot }\end{array}$ & $\begin{array}{c}{ }^{238} \mathrm{U} \\
{ }^{206} \mathrm{~Pb} \\
\end{array}$ & $1 \sigma$ & $\begin{array}{l}{ }^{207} \mathrm{~Pb} \\
{ }^{206} \mathrm{~Pb} \\
\end{array}$ & $1 \sigma$ & $\begin{array}{c}{ }^{206} \mathrm{~Pb} /{ }^{238} \mathrm{U} \\
\text { age }\end{array}$ & $1 \sigma$ & $\begin{array}{c}{ }^{207} \mathrm{~Pb} /{ }^{206} \mathrm{~Pb} \\
\text { age } \\
\end{array}$ & $1 \sigma$ & \\
\hline \multicolumn{10}{|c|}{ ZAP-33 (P) } \\
\hline Grain 2* & 18.697 & 0.867 & 0.05319 & 0.00038 & 336 & 15 & 345 & 15 & \\
\hline Grain 3* & 18.738 & 0.869 & 0.05273 & 0.00038 & 335 & 15 & 324 & 16 & \\
\hline Grain 4* & 18.403 & 0.857 & 0.05335 & 0.00042 & 341 & 15 & 358 & 18 & \\
\hline Grain 5 & 17.999 & 0.838 & 0.05488 & 0.00041 & 349 & 16 & 409 & 17 & \\
\hline Grain 6* & 18.798 & 0.871 & 0.05377 & 0.00042 & 334 & 15 & 360 & 17 & \\
\hline Grain 7* & 18.566 & 0.872 & 0.05353 & 0.00054 & 338 & 15 & 353 & 24 & \\
\hline Grain 9* & 18.501 & 0.857 & 0.05351 & 0.00044 & 339 & 15 & 363 & 18 & \\
\hline Grain 12 & 18.133 & 0.261 & 0.05298 & 0.00051 & 346 & 5 & 341 & 21 & \\
\hline Grain 13 & 19.207 & 0.292 & 0.05517 & 0.00052 & 327 & 5 & 406 & 21 & \\
\hline Grain 14 & 18.241 & 0.263 & 0.05241 & 0.00045 & 344 & 5 & 346 & 19 & \\
\hline Grain 15 & 18.121 & 0.242 & 0.05403 & 0.00035 & 346 & 5 & 381 & 13 & \\
\hline Grain 18 & 18.596 & 0.250 & 0.05285 & 0.00034 & 338 & 4 & 336 & 12 & Concordia Aqe $=340 \pm 3 \mathrm{Ma}$ \\
\hline Grain 20 & 18.769 & 0.271 & 0.05447 & 0.00052 & 335 & 5 & 386 & 21 & Cove \\
\hline Grain $23^{*}$ & 18.596 & 0.280 & 0.05299 & 0.00046 & 338 & 5 & 363 & 22 & 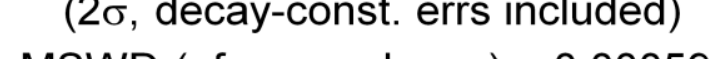 \\
\hline Grain 25 & 19.187 & 0.304 & 0.05469 & 0.00060 & 328 & 5 & 413 & 27 & MSWD (of concordance) $=0.00059$ \\
\hline Grain $26^{*}$ & 18.254 & 0.295 & 0.05310 & 0.00068 & 344 & 5 & 374 & 26 & Probability (of concordance) $=0.98$ \\
\hline Grain 28 & 19.094 & 0.299 & 0.05355 & 0.00051 & 329 & 5 & 389 & 26 & \\
\hline Grain 29 & 18.111 & 0.289 & 0.05374 & 0.00051 & 346 & 5 & 383 & 25 & \\
\hline \multicolumn{10}{|l|}{ ZAP-33 (F) } \\
\hline Grain $2 *$ & 19.273 & 0.655 & 0.05300 & 0.00032 & 326 & 11 & 345 & 15 & \\
\hline Grain 3 & 19.315 & 0.656 & 0.05254 & 0.00032 & 325 & 11 & 324 & 16 & \\
\hline Grain 4* & 18.969 & 0.651 & 0.05316 & 0.00037 & 331 & 11 & 358 & 18 & \\
\hline Grain 5 & 18.552 & 0.636 & 0.05468 & 0.00036 & 338 & 11 & 409 & 17 & \\
\hline Grain 6 & 19.376 & 0.659 & 0.05357 & 0.00037 & 324 & 11 & 360 & 17 & \\
\hline Grain 7* & 19.138 & 0.667 & 0.05333 & 0.00050 & 328 & 11 & 353 & 24 & \\
\hline Grain $9^{*}$ & 19.070 & 0.647 & 0.05331 & 0.00039 & 329 & 11 & 363 & 18 & \\
\hline Grain 12 & 18.644 & 0.287 & 0.05281 & 0.00049 & 337 & 5 & 341 & 21 & \\
\hline Grain 13 & 19.748 & 0.319 & 0.05500 & 0.00049 & 318 & 5 & 406 & 21 & \\
\hline Grain 14 & 18.755 & 0.289 & 0.05225 & 0.00042 & 335 & 5 & 346 & 19 & \\
\hline Grain 15 & 18.631 & 0.267 & 0.05386 & 0.00031 & 337 & 5 & 381 & 13 & \multirow{8}{*}{$\begin{array}{l}\text { Concordia Age }=332 \pm 3 \mathrm{Ma} \\
\begin{array}{r}(95 \% \text { confidence, decay-const. errs } \\
\text { included) }\end{array} \\
\text { MSWD (of concordance) }=0.0088, \\
\text { Probability (of concordance) }=0.93\end{array}$} \\
\hline Grain $18^{*}$ & 19.119 & 0.276 & 0.05269 & 0.00029 & 329 & 5 & 336 & 12 & \\
\hline Grain 20 & 19.298 & 0.297 & 0.05430 & 0.00050 & 326 & 5 & 386 & 21 & \\
\hline Grain $23 *$ & 19.144 & 0.213 & 0.05292 & 0.00036 & 328 & 4 & 363 & 22 & \\
\hline Grain 25 & 19.752 & 0.240 & 0.05462 & 0.00053 & 318 & 4 & 413 & 27 & \\
\hline Grain $26^{*}$ & 18.792 & 0.238 & 0.05303 & 0.00062 & 334 & 4 & 374 & 26 & \\
\hline Grain 28 & 19.656 & 0.235 & 0.05348 & 0.00043 & 320 & 4 & 389 & 26 & \\
\hline Grain $29 *$ & 18.644 & 0.230 & 0.05367 & 0.00043 & 337 & 4 & 383 & 25 & \\
\hline
\end{tabular}


Table 2.

LA-ICP-MS zircon results for the Huaco granitic complex (Sierra de Velasco)

\begin{tabular}{|c|c|c|c|c|c|c|c|c|c|}
\hline $\begin{array}{l}\text { Grain } \\
\text { spot }\end{array}$ & $\begin{array}{r}{ }^{238} \mathrm{U} \\
{ }^{206} \mathrm{~Pb} \\
\end{array}$ & $1 \sigma$ & $\begin{array}{l}{ }^{207} \mathrm{~Pb} \\
{ }^{206} \mathrm{~Pb} \\
\end{array}$ & $1 \sigma$ & $\begin{array}{c}{ }^{206} \mathrm{~Pb} /{ }^{238} \mathrm{U} \\
\text { age }\end{array}$ & $1 \sigma$ & $\begin{array}{c}{ }^{207} \mathrm{~Pb} /{ }^{206} \mathrm{~Pb} \\
\text { age }\end{array}$ & $1 \sigma$ & \\
\hline \multicolumn{10}{|c|}{ HUA-12 (P) } \\
\hline Grain 3 & 17.200 & 0.441 & 0.05515 & 0.00065 & 364 & 9 & 419 & 26 & \\
\hline Grain 4 & 16.956 & 0.426 & 0.05779 & 0.00053 & 369 & 9 & 522 & 20 & \\
\hline Grain 7 & 16.737 & 0.451 & 0.05178 & 0.00081 & 374 & 10 & 276 & 35 & \\
\hline Grain 9 & 16.512 & 0.419 & 0.05630 & 0.00062 & 379 & 9 & 464 & 24 & \multirow{5}{*}{$\begin{array}{c}\text { Concordia Age }=357 \pm 3 \mathrm{Ma}^{\dagger} \\
(2 \sigma, \text { decay-const. errs included) } \\
\text { MSWD (of concordance) }=0.12, \\
\text { Probability (of concordance) }=0.73\end{array}$} \\
\hline Grain $11^{*}$ & 16.890 & 0.452 & 0.05360 & 0.00045 & 371 & 10 & 354 & 19 & \\
\hline Grain 12 & 16.772 & 0.471 & 0.05691 & 0.00068 & 373 & 10 & 488 & 26 & \\
\hline Grain 15 & 18.580 & 0.521 & 0.06948 & 0.00071 & 338 & 9 & 913 & 21 & \\
\hline Grain 18 & 15.725 & 0.425 & 0.07335 & 0.00081 & 397 & 10 & 1024 & 22 & \\
\hline Grain 19 & 15.747 & 0.420 & 0.05327 & 0.00048 & 397 & 10 & 340 & 20 & \\
\hline \multicolumn{10}{|c|}{ HUA-12 (F) } \\
\hline Grain 3 & 18.016 & 0.253 & 0.05525 & 0.00053 & 348 & 5 & 422 & 21 & \\
\hline Grain 4 & 17.760 & 0.231 & 0.05789 & 0.00037 & 353 & 4 & 526 & 14 & \\
\hline Grain 7 & 17.531 & 0.290 & 0.05187 & 0.00073 & 358 & 6 & 280 & 32 & \\
\hline Grain 8* & 17.688 & 0.262 & 0.05379 & 0.00034 & 355 & 5 & 362 & 14 & \\
\hline Grain 9 & 17.295 & 0.233 & 0.05640 & 0.00049 & 362 & 5 & 468 & 19 & \multirow{6}{*}{$\begin{array}{c}\text { Concordia Age = } 368 \pm 6 \mathrm{Ma} \\
(2 \sigma, \text { decay-const. errs included) } \\
\text { MSWD (of concordance) }=3.2, \\
\text { robability (of concordance) }=0.072\end{array}$} \\
\hline Grain $11^{*}$ & 17.495 & 0.186 & 0.05368 & 0.00017 & 358 & 4 & 358 & 7 & \\
\hline Grain 12 & 17.373 & 0.242 & 0.05700 & 0.00051 & 361 & 5 & 491 & 19 & \\
\hline Grain 15 & 19.246 & 0.264 & 0.06958 & 0.00045 & 327 & 4 & 916 & 13 & \\
\hline Grain 18 & 16.288 & 0.185 & 0.07346 & 0.00057 & 384 & 4 & 1027 & 16 & \\
\hline Grain 19 & 16.311 & 0.170 & 0.05335 & 0.00023 & 384 & 4 & 344 & 10 & \\
\hline
\end{tabular}

\footnotetext{
This age (LA-ICP-MS U-Pb in monacite) is similar to that reported by Grosse et al. (2009).
} 
Table 2.

LA-ICP-MS zircon results for the San blas pluton (Sierra de Velasco)

\begin{tabular}{|c|c|c|c|c|c|c|c|c|c|}
\hline $\begin{array}{l}\text { Grain } \\
\text { spot }\end{array}$ & ${ }^{{ }^{238} \mathrm{U}}$ & $1 \sigma$ & $\begin{array}{l}{ }^{207} \mathrm{~Pb} \\
{ }^{206} \mathrm{~Pb}\end{array}$ & $1 \sigma$ & $\begin{array}{c}{ }^{206} \mathrm{~Pb} /{ }^{238} \mathrm{U} \\
\text { age }\end{array}$ & $1 \sigma$ & $\begin{array}{c}{ }^{207} \mathrm{~Pb} /{ }^{206} \mathrm{~Pb} \\
\text { age }\end{array}$ & $1 \sigma$ & \\
\hline \multicolumn{10}{|l|}{ VEL-6017 (P) } \\
\hline Grain 1a & 18.016 & 0.217 & 0.05411 & 0.00044 & 348 & 4 & 656 & 46 & \\
\hline Grain $4 a^{*}$ & 18.622 & 0.247 & 0.05371 & 0.00069 & 337 & 4 & 392 & 29 & \\
\hline Grain $5 a^{*}$ & 18.429 & 0.201 & 0.05295 & 0.00043 & 341 & 4 & 345 & 15 & \\
\hline Grain 6a & 17.240 & 0.256 & 0.05444 & 0.00055 & 363 & 5 & 443 & 22 & \\
\hline Grain 9a & 17.345 & 0.265 & 0.05735 & 0.00085 & 361 & 5 & 575 & 32 & \multirow{6}{*}{$\begin{array}{c}\text { Concordia Age }=340 \pm 2 \mathrm{Ma} \\
(2 \sigma, \text { decay-const. errs included) } \\
\text { MSWD (of concordance) }=0.70, \\
\text { Probability (of concordance) }=0.40\end{array}$} \\
\hline Grain $11 \mathrm{a}^{*}$ & 18.254 & 0.240 & 0.05304 & 0.00050 & 344 & 4 & 342 & 18 & \\
\hline Grain $13 a^{*}$ & 18.701 & 0.264 & 0.05335 & 0.00060 & 336 & 5 & 389 & 24 & \\
\hline Grain 16a & 17.912 & 0.196 & 0.05278 & 0.00046 & 350 & 4 & 353 & 16 & \\
\hline Grain 2b & 19.486 & 0.701 & 0.05742 & 0.00096 & 323 & 11 & 769 & 81 & \\
\hline Grain 8a & 18.453 & 0.342 & 0.05280 & 0.00090 & 340 & 6 & 599 & 28 & \\
\hline Grain $12 \mathrm{a}^{*}$ & 18.265 & 0.264 & 0.05313 & 0.00063 & 344 & 5 & 1147 & 42 & \multirow{5}{*}{$\begin{array}{l}\text { Mean }{ }^{206} \mathrm{~Pb} / 238 \mathrm{U} \text { Age } \\
340 \pm 3 \mathrm{Ma}^{\dagger} \\
\mathrm{N}=16 / 19 ; \mathrm{MSWD}=1.5 \\
\text { (Error ellipses are } 1 \sigma \text { ) }\end{array}$} \\
\hline Grain $17 \mathrm{a}$ & 18.721 & 0.285 & 0.05144 & 0.00069 & 335 & 5 & 2013 & 82 & \\
\hline VEL-6017 (F) & 17.911 & 0.201 & 0.05829 & 0.00049 & 350 & 4 & 1378 & 52 & \\
\hline Grain 1a & 18.016 & 0.217 & 0.05411 & 0.00044 & 348 & 4 & 656 & 46 & \\
\hline Grain 4a & 18.622 & 0.247 & 0.05371 & 0.00069 & 337 & 4 & 392 & 29 & \\
\hline Grain 5a & 18.429 & 0.201 & 0.05295 & 0.00043 & 341 & 4 & 345 & 15 & \multirow{9}{*}{ 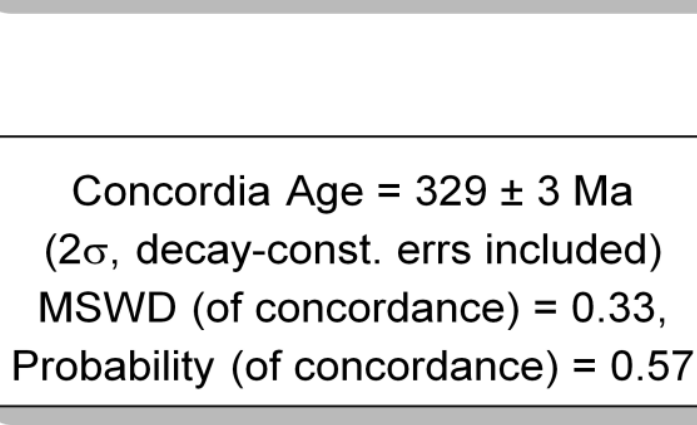 } \\
\hline Grain 6a & 18.224 & 0.230 & 0.05458 & 0.00047 & 344 & 4 & 443 & 22 & \\
\hline Grain 9a & 18.335 & 0.242 & 0.05750 & 0.00079 & 342 & 4 & 575 & 32 & \\
\hline Grain 11a & 19.296 & 0.198 & 0.05317 & 0.00040 & 326 & 3 & 342 & 18 & \\
\hline Grain 13a & 19.768 & 0.230 & 0.05348 & 0.00053 & 318 & 4 & 389 & 24 & \\
\hline Grain 16a* & 18.974 & 0.233 & 0.05300 & 0.00038 & 331 & 4 & 353 & 16 & \\
\hline Grain $2 b$ & 19.486 & 0.701 & 0.05742 & 0.00096 & 323 & 11 & 769 & 81 & \\
\hline Grain 8a & 19.506 & 0.335 & 0.05294 & 0.00086 & 322 & 5 & 599 & 28 & \\
\hline Grain $12 \mathrm{a}^{*}$ & 19.307 & 0.234 & 0.05326 & 0.00055 & 326 & 4 & 1147 & 42 & \\
\hline Grain $17 \mathrm{a}$ & 19.832 & 0.330 & 0.05166 & 0.00064 & 317 & 5 & 2013 & 82 & \\
\hline Grain $18 \mathrm{a}$ & 18.974 & 0.239 & 0.05853 & 0.00040 & 331 & 4 & 1378 & 52 & \\
\hline
\end{tabular}

†revious age (SHRIMP U-Pb in zircon) reported by Dahlquist et al. (2006). 
Table 2.

LA-ICP-MS zircon results for the Cerro La Gloria (Sierra de Famatina)

\begin{tabular}{|c|c|c|c|c|c|c|c|c|}
\hline $\begin{array}{l}\text { Grain } \\
\text { spot }\end{array}$ & $\begin{array}{c}{ }^{238} \mathrm{U} \\
{ }^{206} \mathrm{~Pb} \\
\end{array}$ & $1 \sigma$ & $\begin{array}{l}{ }^{207} \mathrm{~Pb} \\
{ }^{206} \mathrm{~Pb} \\
\end{array}$ & $1 \sigma$ & $\begin{array}{c}{ }^{206} \mathrm{~Pb} /{ }^{238} \mathrm{U} \\
\text { age }\end{array}$ & $1 \sigma$ & $\begin{array}{c}{ }^{207} \mathrm{~Pb} /{ }^{206} \mathrm{~Pb} \\
\text { age } \\
\end{array}$ & $1 \sigma$ \\
\hline \multicolumn{9}{|c|}{ FAM-177 (P) } \\
\hline Grain 2 & 17.157 & 0.316 & 0.05558 & 0.00058 & 365 & 7 & 444 & 22 \\
\hline Grain $8^{*}$ & 17.745 & 0.337 & 0.05376 & 0.00059 & 353 & 7 & 359 & 23 \\
\hline Grain 9 & 18.072 & 0.325 & 0.05541 & 0.00054 & 347 & 6 & 429 & 20 \\
\hline Grain 12 & 17.180 & 0.284 & 0.05480 & 0.00058 & 365 & 6 & 409 & 14 \\
\hline Grain $15^{*}$ & 17.850 & 0.290 & 0.05377 & 0.00056 & 351 & 6 & 379 & 13 \\
\hline Grain 18 & 19.479 & 0.309 & 0.06168 & 0.00061 & 323 & 5 & 676 & 10 \\
\hline Grain 19 & 19.242 & 0.310 & 0.06003 & 0.00059 & 327 & 5 & 618 & 9 \\
\hline
\end{tabular}

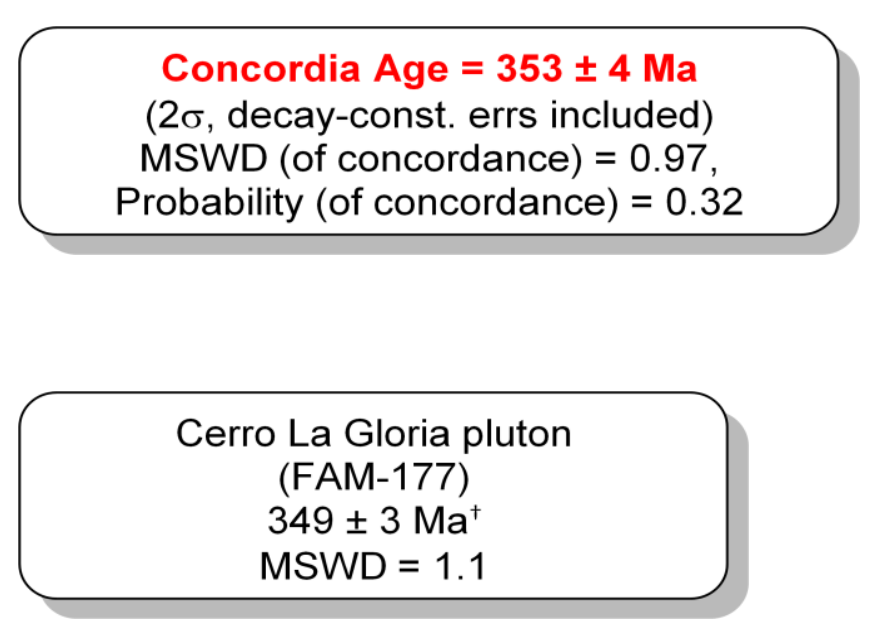

\section{FAM-177 (F)}

\begin{tabular}{lllllllll} 
Grain 2 & 17.736 & 0.298 & 0.05558 & 0.00036 & 354 & 6 & 444 & 22 \\
Grain 8* & 18.344 & 0.320 & 0.05377 & 0.00039 & 342 & 6 & 359 & 23 \\
Grain 9 & 18.682 & 0.303 & 0.05542 & 0.00030 & 336 & 5 & 429 & 20 \\
Grain 12 & 17.530 & 0.501 & 0.05480 & 0.00034 & 358 & 10 & 409 & 14 \\
Grain 15* & 18.213 & 0.517 & 0.05377 & 0.00032 & 345 & 10 & 379 & 13 \\
Grain 18 & 19.875 & 0.560 & 0.06168 & 0.00030 & 316 & 9 & 676 & 10 \\
Grain 19 & 19.633 & 0.556 & 0.06003 & 0.00029 & 320 & 9 & 618 & 9 \\
\hline
\end{tabular}
Concordia Age $=346 \pm 13 \mathrm{Ma}$ (95\% confidence, decay-const. errs included)
MSWD (of concordance) $=9.0$,
Probability (of concordance) $=0.003$

'Previous age (SHRIMP U-Pb in zircon) reported by Alasino et al. (2012). 
Table 3a.

Laser ablation Hf isotope data for igneous dated zircons from Sierras Pampeanas of Argentina (location of samples in Fig. 1 and Table 1).

\begin{tabular}{|c|c|c|c|c|c|c|c|c|c|c|c|c|}
\hline Sample & Grain & $\begin{array}{l}\text { Age } \\
\text { (Ma) }\end{array}$ & ${ }^{176} \mathrm{Hf} /{ }^{177} \mathrm{Hf}$ & $\pm(2 \sigma)$ & ${ }^{176} \mathrm{Lu} /{ }^{177} \mathrm{Hf}$ & $\pm(2 \sigma)$ & ${ }^{176} \mathbf{Y b} /{ }^{177} \mathbf{H f}$ & $\begin{array}{l}\text { Age } \\
(\text { Ma) }\end{array}$ & $\varepsilon \mathbf{H f}$ (today) & $\pm(2 \sigma)$ & $\varepsilon \mathbf{H f}(\mathrm{t})$ & $\mathbf{T}_{\mathrm{DM}} \mathbf{H f}$ \\
\hline \multicolumn{13}{|c|}{ Early-Middle Ordovician granitic rocks (Ancasti, Famatina, Valle Fértil, and Mazán mountain ranges) } \\
\hline \multirow[t]{4}{*}{ ANC-11030a } & $4 / 3^{\dagger}$ & & & & & & & & & & & \\
\hline & ANC11030a_8a & 466 & 0.282464 & 0.000062 & 0.001761 & 0.000100 & 0.068127 & 466 & -11.4 & 2.2 & -1.5 & 1.5 \\
\hline & ANC11030a_3a & 466 & 0.282386 & 0.000041 & 0.002333 & 0.000113 & 0.080279 & 466 & -14.1 & 1.4 & -4.5 & 1.6 \\
\hline & ANC11030a_2a & 466 & 0.282396 & 0.000039 & 0.001887 & 0.000120 & 0.075972 & 466 & -13.7 & 1.4 & -4.0 & 1.7 \\
\hline Average & & & & & & & & & & & -3.3 & 1.5 \\
\hline \multirow{6}{*}{ FAM-7086 } & $8 / 6$ & & & & & & & & & & & \\
\hline & FAM7086_1b & 489 & 0.282198 & 0.000043 & 0.002483 & 0.000073 & 0.076713 & 489 & -20.8 & 1.5 & -10.7 & 2.0 \\
\hline & FAM7086_5a & 489 & 0.282110 & 0.000035 & 0.002693 & 0.000144 & 0.088002 & 489 & -23.9 & 1.3 & -13.9 & 2.2 \\
\hline & FAM7086_3a & 489 & 0.281986 & 0.000030 & 0.004196 & 0.000377 & 0.119129 & 481 & -28.3 & 1.1 & -18.9 & 2.5 \\
\hline & FAM7086_4a & 489 & 0.282055 & 0.000065 & 0.002380 & 0.000074 & 0.072752 & 489 & -25.8 & 2.3 & -15.7 & 2.3 \\
\hline & FAM7086_2b & 489 & 0.282173 & 0.000037 & 0.002643 & 0.000108 & 0.085036 & 489 & -21.6 & 1.3 & -11.6 & 2.0 \\
\hline Average & & & & & & & & & & & -14.2 & 2.2 \\
\hline \multirow[t]{10}{*}{ SVF-577 } & $13 / 11$ & & & & & & & & & & & \\
\hline & SVF577_17a & 464 & 0.282324 & 0.000061 & 0.000581 & 0.000013 & 0.025969 & 464 & -16.3 & 2.2 & -6.1 & 1.7 \\
\hline & SVF577_15a & 464 & 0.282375 & 0.000057 & 0.000902 & 0.000040 & 0.037338 & 464 & -14.5 & 2.0 & -4.5 & 1.6 \\
\hline & SVF577_13a & 464 & 0.282301 & 0.000046 & 0.000466 & 0.000016 & 0.020208 & 464 & -17.1 & 1.6 & -6.9 & 1.8 \\
\hline & SVF577_11a & 464 & 0.282335 & 0.000036 & 0.000260 & 0.000008 & 0.009712 & 464 & -15.9 & 1.3 & -5.7 & 1.7 \\
\hline & SVF577_10a & 464 & 0.282366 & 0.000046 & 0.000595 & 0.000037 & 0.020873 & 464 & -14.8 & 1.6 & -4.7 & 1.6 \\
\hline & SVF577_8a & 464 & 0.282334 & 0.000063 & 0.000434 & 0.000035 & 0.016921 & 464 & -16.0 & 2.2 & -5.8 & 1.7 \\
\hline & SVF577_7a & 464 & 0.282365 & 0.000067 & 0.000538 & 0.000037 & 0.021245 & 464 & -14.9 & 2.4 & -4.7 & 1.6 \\
\hline & SVF577_6a & 464 & 0.282380 & 0.000043 & 0.000445 & 0.000022 & 0.017711 & 464 & -14.3 & 1.5 & -4.1 & 1.6 \\
\hline & SVF577_1a & 464 & 0.282247 & 0.000059 & 0.000375 & 0.000019 & 0.011942 & 464 & -19.0 & 2.1 & -8.8 & 1.9 \\
\hline Average & & & & & & & & & & & -5.7 & 1.7 \\
\hline \multirow[t]{6}{*}{ VMA-1018 } & $8 / 8$ & & & & & & & & & & & \\
\hline & VEL_1018_9a & 476 & 0.282248 & 0.000032 & 0.001231 & 0.000083 & 0.056862 & 476 & -19.0 & 1.1 & -8.8 & 1.9 \\
\hline & VEL_1018_8a & 476 & 0.282324 & 0.000030 & 0.002385 & 0.000276 & 0.121735 & 476 & -16.3 & 1.1 & -6.4 & 1.7 \\
\hline & VEL_1018_7a & 476 & 0.282282 & 0.000034 & 0.003245 & 0.000219 & 0.147306 & 476 & -17.8 & 1.2 & -8.2 & 1.8 \\
\hline & VEL_1018_6a & 476 & 0.282302 & 0.000044 & 0.003756 & 0.000648 & 0.145780 & 476 & -17.1 & 1.6 & -7.7 & 1.8 \\
\hline & VEL_1018_5a & 476 & 0.282283 & 0.000035 & 0.001581 & 0.000157 & 0.066127 & 476 & -17.8 & 1.2 & -7.7 & 1.8 \\
\hline
\end{tabular}




\begin{tabular}{|c|c|c|c|c|c|c|c|c|c|c|c|}
\hline VEL_1018_4a & 476 & 0.282349 & 0.000021 & 0.001904 & 0.000171 & 0.095304 & 476 & -15.4 & 0.8 & -5.4 & 1.7 \\
\hline VEL_1018_3a & 476 & 0.282253 & 0.000030 & 0.002041 & 0.000031 & 0.093116 & 476 & -18.8 & 1.2 & -8.9 & 1.9 \\
\hline VEL_1018_1a & 476 & 0.282356 & 0.000042 & 0.001854 & 0.000089 & 0.091752 & 476 & -15.2 & 1.5 & -5.2 & 1.7 \\
\hline & & & & & & & & & & -7.3 & 1.8 \\
\hline
\end{tabular}

Average

Total number of analyses / number chosen for $\varepsilon \mathrm{Hf}$ calculation.

${ }^{\S}$ VEL-6017 defines two Hf compositions populations. 
Table 3a (continuation).

Laser ablation Hf isotope data for igneous dated zircons from Sierras Pampeanas of Argentina (location of samples in Fig. 1 and Table 1).

\begin{tabular}{|c|c|c|c|c|c|c|c|c|c|c|c|c|}
\hline Sample & Grain & $\begin{array}{c}\text { Age } \\
\text { (Ma) }\end{array}$ & ${ }^{176} \mathrm{Hf} /{ }^{177} \mathrm{Hf}$ & $\pm(2 \sigma)$ & ${ }^{176} \mathrm{Lu} /{ }^{177} \mathrm{Hf}$ & $\pm(2 \sigma)$ & ${ }^{176} \mathrm{Yb} /{ }^{177} \mathrm{Hf}$ & $\begin{array}{c}\text { Age } \\
\text { (Ma) }\end{array}$ & $\varepsilon \mathbf{H f}$ (today) & $\pm(2 \sigma)$ & $\varepsilon \mathbf{H f}(\mathbf{t})$ & $\mathbf{T}_{\mathrm{DM}} \mathrm{Hf}$ \\
\hline \multicolumn{13}{|c|}{ Late-Middle Devonian granitic rocks (Achala batholith) } \\
\hline \multirow[t]{8}{*}{ DAL-1 } & $7 / 7$ & & & & & & & & & & & \\
\hline & Dal1_8a & 372 & 0.282372 & 0.000062 & 0.000822 & 0.000032 & 0.038368 & 372 & -14.6 & 2.2 & -6.5 & 1.8 \\
\hline & Dal1_7a & 372 & 0.282462 & 0.000032 & 0.000659 & 0.000008 & 0.031781 & 372 & -11.4 & 1.1 & -3.3 & 1.6 \\
\hline & Dal1_6a & 372 & 0.282427 & 0.000045 & 0.000721 & 0.000045 & 0.033232 & 372 & -12.7 & 1.6 & -4.7 & 1.6 \\
\hline & Dal1_4a & 372 & 0.282482 & 0.000060 & 0.000756 & 0.000009 & 0.037214 & 372 & -10.7 & 2.1 & -2.6 & 1.4 \\
\hline & Dal1_3a & 372 & 0.282475 & 0.000033 & 0.000793 & 0.000018 & 0.037658 & 372 & -11.0 & 1.2 & -2.9 & 1.5 \\
\hline & Dal1_2a & 372 & 0.282498 & 0.000039 & 0.000586 & 0.000021 & 0.028253 & 372 & -10.1 & 1.4 & -2.0 & 1.4 \\
\hline & Dal1_1a & 372 & 0.282454 & 0.000028 & 0.000591 & 0.000009 & 0.027818 & 372 & -11.7 & 1.0 & -3.7 & 1.5 \\
\hline Average & & & & & & & & & & & -3.6 & 1.5 \\
\hline \multirow[t]{8}{*}{ NPE-14 } & $7 / 7$ & & & & & & & & & & & \\
\hline & NPE_14_3c & 369 & 0.282424 & 0.000042 & 0.000790 & 0.000021 & 0.041036 & 369 & -12.8 & 1.5 & -4.7 & 1.6 \\
\hline & NPE_14_3b & 369 & 0.282449 & 0.000046 & 0.000779 & 0.000060 & 0.039925 & 369 & -11.9 & 1.6 & -3.8 & 1.5 \\
\hline & NPE_14_3a & 369 & 0.282312 & 0.000049 & 0.001181 & 0.000144 & 0.048790 & 369 & -16.7 & 1.7 & -8.7 & 1.8 \\
\hline & NPE_14_2d & 369 & 0.282373 & 0.000048 & 0.000691 & 0.000048 & 0.035585 & 369 & -14.6 & 1.7 & -6.5 & 1.7 \\
\hline & NPE_14_2c & 369 & 0.282383 & 0.000052 & 0.000682 & 0.000043 & 0.034580 & 369 & -14.2 & 1.9 & -6.1 & 1.7 \\
\hline & NPE_14_2b & 369 & 0.282415 & 0.000049 & 0.000708 & 0.000053 & 0.036478 & 369 & -13.1 & 1.7 & -5.0 & 1.6 \\
\hline & NPE_14_2a & 369 & 0.282367 & 0.000045 & 0.000895 & 0.000050 & 0.037973 & 369 & -14.8 & 1.6 & -6.7 & 1.7 \\
\hline Average & & & & & & & & & & & -5.9 & 1.6 \\
\hline \multirow[t]{8}{*}{ ACH-140 } & $10 / 7$ & & & & & & & & & & & \\
\hline & ACH140_10a & 366 & 0.282484 & 0.000023 & 0.000978 & 0.000051 & 0.051003 & 366 & -10.6 & 0.8 & -2.7 & 1.4 \\
\hline & ACH140_9a & 366 & 0.282468 & 0.000031 & 0.001216 & 0.000036 & 0.061520 & 366 & -11.2 & 1.1 & -3.4 & 1.5 \\
\hline & ACH140_8a & 366 & 0.282380 & 0.000050 & 0.001339 & 0.000183 & 0.055740 & 366 & -14.3 & 1.8 & -6.5 & 1.7 \\
\hline & ACH140_6a & 366 & 0.282480 & 0.000030 & 0.000836 & 0.000031 & 0.043617 & 366 & -10.8 & 1.1 & -2.8 & 1.4 \\
\hline & ACH140_5a & 366 & 0.282454 & 0.000025 & 0.000891 & 0.000017 & 0.044674 & 366 & -11.7 & 0.9 & -3.8 & 1.5 \\
\hline & ACH140_2b & 366 & 0.282434 & 0.000028 & 0.000893 & 0.000074 & 0.048033 & 366 & -12.4 & 1.0 & -4.5 & 1.5 \\
\hline & ACH140_1a & 366 & 0.282477 & 0.000025 & 0.000921 & 0.000061 & 0.048627 & 366 & -10.9 & 0.9 & -3.0 & 1.5 \\
\hline Average & & & & & & & & & & & -3.8 & 1.5 \\
\hline \multirow[t]{2}{*}{ NPE-10 } & $10 / 9$ & & & & & & & & & & & \\
\hline & NPE_10_7a & 369 & 0.282485 & 0.000033 & 0.000892 & 0.000032 & 0.042838 & 369 & -10.6 & 1.2 & -2.6 & 1.43 \\
\hline
\end{tabular}




\begin{tabular}{llllllllllll} 
NPE_10_6a & 369 & 0.282371 & 0.000048 & 0.000794 & 0.000048 & 0.034683 & 369 & -14.6 & 1.7 & -6.6 & 1.7 \\
NPE_10_5a & 369 & 0.282423 & 0.000030 & 0.001099 & 0.000069 & 0.048549 & 369 & -12.8 & 1.1 & -4.9 & 1.6 \\
NPE_10_4a & 369 & 0.282447 & 0.000036 & 0.000850 & 0.000020 & 0.039005 & 369 & -11.9 & 1.3 & -3.9 & 1.5 \\
NPE_10_3b & 369 & 0.282493 & 0.000033 & 0.000628 & 0.000051 & 0.031648 & 369 & -10.3 & 1.2 & -2.3 & 1.4 \\
NPE_10_2a & 369 & 0.282464 & 0.000025 & 0.001387 & 0.000056 & 0.066827 & 369 & -11.3 & 0.9 & -3.5 & 1.5 \\
NPE_10_1c & 369 & 0.282453 & 0.000043 & 0.001146 & 0.000016 & 0.048249 & 369 & -11.7 & 1.5 & -3.8 & 1.5 \\
NPE_10_1b & 369 & 0.282500 & 0.000036 & 0.000997 & 0.000013 & 0.048892 & 369 & -10.1 & 1.3 & -2.1 & 1.4 \\
NPE_10_1a & 369 & 0.282475 & 0.000049 & 0.000873 & 0.000033 & 0.040185 & 369 & -11.0 & 1.8 & -3.0 & 1.5 \\
& & & & & & & & & & -3.6 & $\mathbf{1 . 5}$ \\
\hline
\end{tabular}


Table 3a (continuation).

Laser ablation Hf isotope data for igneous dated zircons from Sierras Pampeanas of Argentina (location of samples in Fig. 1 and Table 1).

\begin{tabular}{|c|c|c|c|c|c|c|c|c|c|c|c|c|}
\hline Sample & Grain & $\begin{array}{c}\text { Age } \\
\text { (Ma) }\end{array}$ & ${ }^{176} \mathrm{Hf} /{ }^{177} \mathrm{Hf}$ & $\pm(2 \sigma)$ & ${ }^{176} \mathrm{Lu} /{ }^{177} \mathrm{Hf}$ & $\pm(2 \sigma)$ & ${ }^{176} \mathbf{Y b} /{ }^{177} \mathbf{H f}$ & $\begin{array}{c}\text { Age } \\
\text { (Ma) }\end{array}$ & $\varepsilon \mathbf{H f}$ (today) & $\pm(2 \sigma)$ & $\varepsilon H f(t)$ & $\mathbf{T}_{\mathrm{DM}} \mathbf{H f}$ \\
\hline
\end{tabular}

Early Carboniferous granitic rocks (Fiambalá, Velasco, Famatina and Zapata mountain ranges).

FIA-17

$\begin{array}{llllllll}\text { FIA17_6b } & 322 & 0.282477 & 0.000074 & 0.000544 & 0.000002 & 0.026722 & 322 \\ \text { FIA17_4a } & 322 & 0.282493 & 0.000046 & 0.001762 & 0.000147 & 0.097517 & 322 \\ \text { FIA17_3b } & 322 & 0.282432 & 0.000067 & 0.000916 & 0.000027 & 0.045564 & 322 \\ \text { FIA17_3a } & 322 & 0.282359 & 0.000068 & 0.000627 & 0.000019 & 0.030277 & 322 \\ \text { FIA17_1b } & 322 & 0.282469 & 0.000064 & 0.000677 & 0.000011 & 0.034428 & 322 \\ \text { FIA17_1a } & 322 & 0.282445 & 0.000061 & 0.000557 & 0.000014 & 0.027907 & 322\end{array}$

-10.9
-10.3
-12.5
-15.1
-11.2
-12.0

2.6
1.6
2.4
2.4
2.3
2.16

$\begin{array}{ll}-3.9 & 1.5 \\ -3.5 & 1.4 \\ -5.5 & 1.6 \\ -8.0 & 1.7 \\ -4.2 & 1.5 \\ -5.0 & 1.6 \\ \mathbf{- 5 . 0} & \mathbf{1 . 6}\end{array}$

\section{$7 / 5$}

HUA12 6 a HUA12_5b

HUA12_4a

HUA12_3a

HUA12_1a

357

357

357

357

357
0.282523

0.282503

0.282471

0.282405

0.282469
0.000029

0.000051

0.000040

0.000038

0.000059
0.001206

0.001274

0.000989

0.001637

0.000771
0.000169

0.000072

0.000011

0.000033

0.000044
0.059043

0.065866

0.049964

0.084079

0.041285

357
357
357
357
357

Average

3/3

CHI-17

$\begin{array}{ll}\text { CHI7_5a } & 345 \\ \text { CHI7_4a } & 345 \\ \text { CHI7_2a } & 345\end{array}$

Average

FAM-177

\section{1/9}

$\begin{array}{lllll}\text { FAM_177_3b } & 353 & 0.282605 & 0.000055 & 0.001347 \\ \text { FAM_177_6b } & 353 & 0.282666 & 0.000037 & 0.002280 \\ \text { FAM_177_5b } & 353 & 0.282655 & 0.000040 & 0.001772 \\ \text { FAM_177_4b } & 353 & 0.282607 & 0.000031 & 0.001263 \\ \text { FAM_177_4a } & 353 & 0.282667 & 0.000035 & 0.002556 \\ \text { FAM_177_3a } & 353 & 0.282651 & 0.000038 & 0.002223 \\ \text { FAM_177_2a } & 353 & 0.282632 & 0.000052 & 0.001272 \\ \text { FAM_177_1b } & 353 & 0.282628 & 0.000031 & 0.001679\end{array}$

$\begin{array}{lll}0.000027 & 0.063763 & 353 \\ 0.000232 & 0.098271 & 353 \\ 0.000030 & 0.088599 & 353 \\ 0.000027 & 0.059873 & 353 \\ 0.000214 & 0.121723 & 353 \\ 0.000168 & 0.105691 & 353 \\ 0.000140 & 0.057944 & 353 \\ 0.000085 & 0.079175 & 353\end{array}$

-9.3
-10.0
-11.1
-13.4
-11.2

1.0

\section{8}

1.4

1.3

2.1

$\begin{array}{ll}-1.6 & 1.4 \\ -2.4 & 1.4 \\ -3.4 & 1.5 \\ -5.9 & 1.6 \\ -3.4 & 1.5 \\ \mathbf{- 3 . 3} & \mathbf{1 . 5}\end{array}$

0.282363

0.282361

0.282440

0.000051
0.000032

0.001324

0.000140

0.052209

345

$0.000235 \quad 0.062902 \quad 345$

0.000214

0.061438

345

-14.9
-15.0
-12.2

1.8
1.1
1.0

$\begin{array}{ll}-7.6 & 1.7 \\ -7.7 & 1.7 \\ -4.9 & 1.5 \\ \mathbf{- 6 . 7} & \mathbf{1 . 7}\end{array}$

-6.4
-4.2
-4.6
-6.3
-4.2
-4.7
-5.4
-5.6

2.0
1.3
1.4
1.1
1.2
1.3
1.9
1.1

1.2
3.1
2.8
1.3
3.1
2.6
2.2
1.9


$\begin{array}{llllllllllll}\text { FAM_177_1a } & 353 & 0.282716 & 0.000034 & 0.002703 & 0.000258 & 0.131327 & 353 & -2.42 & 1.21 & 4.8 & 0.9\end{array}$

Average

ZAP-33

\section{2/11}

ZAP_33_12a

ZAP_33_11a

ZAP_33_10a

ZAP_33_9a

ZAP_33_8a

ZAP_33_7b

ZAP_33_5a

ZAP_33_3b

ZAP_33_3a

ZAP_33_2a

ZAP_33_1a

$\begin{array}{llll}340 & 0.282409 & 0.000024 & 0.000482 \\ 340 & 0.282409 & 0.000031 & 0.000685 \\ 340 & 0.282424 & 0.000023 & 0.000577 \\ 340 & 0.282379 & 0.000023 & 0.000926 \\ 340 & 0.282407 & 0.000044 & 0.000616 \\ 340 & 0.282396 & 0.000035 & 0.000576 \\ 340 & 0.282438 & 0.000024 & 0.000453 \\ 340 & 0.282447 & 0.000032 & 0.000851 \\ 340 & 0.282431 & 0.000025 & 0.001165 \\ 340 & 0.282394 & 0.000028 & 0.000615 \\ 340 & 0.282401 & 0.000040 & 0.001311\end{array}$

$\begin{array}{lll}0.000017 & 0.022801 & 340 \\ 0.000014 & 0.031634 & 340 \\ 0.000005 & 0.026810 & 340 \\ 0.000024 & 0.044627 & 340 \\ 0.000009 & 0.031501 & 340 \\ 0.000022 & 0.027877 & 340 \\ 0.000002 & 0.020572 & 340 \\ 0.000009 & 0.036220 & 340 \\ 0.000026 & 0.048962 & 340 \\ 0.000017 & 0.028751 & 340 \\ 0.000099 & 0.039749 & 340\end{array}$

-13.3
-13.3

0.9

$\begin{array}{ll}-5.9 & 1.6\end{array}$

$\begin{array}{ll}-5.9 & 1.6\end{array}$

$\begin{array}{llll}-12.8 & 0.8 & -5.3 & 1.6\end{array}$

$\begin{array}{llll}-14.4 & 0.8 & -7.0 & 1.7\end{array}$

$\begin{array}{llll}-13.4 & 1.6 & -5.9 & 1.6\end{array}$

$\begin{array}{llll}-13.8 & 1.2 & -6.3 & 1.7\end{array}$

$\begin{array}{llll}-12.3 & 0.9 & -4.8 & 1.6\end{array}$

$\begin{array}{llll}-12.0 & 1.1 & -4.6 & 1.5\end{array}$

$\begin{array}{llll}-12.5 & 0.9 & -5.2 & 1.6\end{array}$

$\begin{array}{llll}-13.8 & 1.0 & -6.4 & 1.7\end{array}$

$\begin{array}{llll}-13.6 & 1.4 & -6.3 & 1.6\end{array}$

Average

\section{0/10}

VEL_6017_4a 340

$\begin{array}{ll}0.282444 & 0.000057\end{array}$

VEL_6017_1a $340 \quad 0.282410 \quad 0.000080$

0.001671

$\begin{array}{lll}0.000140 & 0.062118 & 340\end{array}$

$-12.1$

2.0

$-4.9$

$-6.0$

1.5

Average

$\begin{array}{ll}\text { VEL_6017_2a } & 340 \\ \text { VEL_6017_1b } & 340 \\ \text { VEL_6017_5b } & 340 \\ \text { VEL_6017_3a } & 340 \\ \text { VEL_6017_2b } & 340\end{array}$

$\begin{array}{lll}0.282543 & 0.000057 & 0.000840 \\ 0.282518 & 0.000071 & 0.000879 \\ 0.282619 & 0.000073 & 0.000554 \\ 0.282574 & 0.000043 & 0.000367 \\ 0.282591 & 0.000049 & 0.000739\end{array}$

$\begin{array}{lll}0.000073 & 0.033059 & 340 \\ 0.000206 & 0.040033 & 340 \\ 0.000007 & 0.028718 & 340 \\ 0.000006 & 0.017919 & 340 \\ 0.000033 & 0.037920 & 340\end{array}$

$-13.3$

$-5.4$ 
Table 3b. Laser ablation Hf isotope data for igneous dated zircons from Sierras Pampeanas of Argentina (location of samples in Fig. 1 and Table 1).

\begin{tabular}{|c|c|c|c|c|c|c|c|c|c|c|c|c|}
\hline Sample & Grain & $\begin{array}{c}\text { Age } \\
\text { (Ma) }\end{array}$ & ${ }^{176} \mathrm{Hf} /{ }^{177} \mathrm{Hf}$ & $\pm(2 \sigma)$ & ${ }^{176} \mathrm{Lu} /{ }^{177} \mathbf{H f}$ & $\pm(2 \sigma)$ & ${ }^{176} \mathbf{Y b} /{ }^{177} \mathbf{H f}$ & $\begin{array}{l}\text { Age } \\
\text { (Ma) }\end{array}$ & $\varepsilon \mathbf{H f}$ (today) & $\pm(2 \sigma)$ & $\varepsilon \mathbf{H f}(\mathbf{t})$ & $\mathbf{T}_{\mathrm{DM}} \mathbf{H f}$ \\
\hline \multicolumn{13}{|c|}{ Early-Middle Ordovician granitic rocks (Ancasti, Famatina, Valle Fértil, and Mazán mountain ranges) } \\
\hline \multirow[t]{5}{*}{ ANC-11030a } & $4 / 4$ & & & & & & & & & & & \\
\hline & ANC11030a_4a* & 466 & 0.282190 & 0.000062 & 0.002783 & 0.000135 & 0.089553 & 466 & -21.1 & 2.2 & -11.5 & 2.07 \\
\hline & ANC11030a_8a & 466 & 0.282464 & 0.000062 & 0.001761 & 0.000100 & 0.068127 & 466 & -11.4 & 2.2 & -1.5 & 1.45 \\
\hline & ANC11030a_3a & 466 & 0.282386 & 0.000041 & 0.002333 & 0.000113 & 0.080279 & 466 & -14.1 & 1.4 & -4.5 & 1.59 \\
\hline & ANC11030a_2a & 466 & 0.282396 & 0.000039 & 0.001887 & 0.000120 & 0.075972 & 466 & -13.7 & 1.4 & -4.0 & 1.57 \\
\hline
\end{tabular}

ALL TABLES: Hf values histograms below each Table, $\mathrm{X}=\varepsilon \mathrm{Hf}(\mathrm{t})$ and $\mathrm{Y}=$ Frequency.

Samples without deleted values are not included in these Tables.

*In blue colour $\mathrm{Hf}$ 'extreme' values deleted in Table 3a.

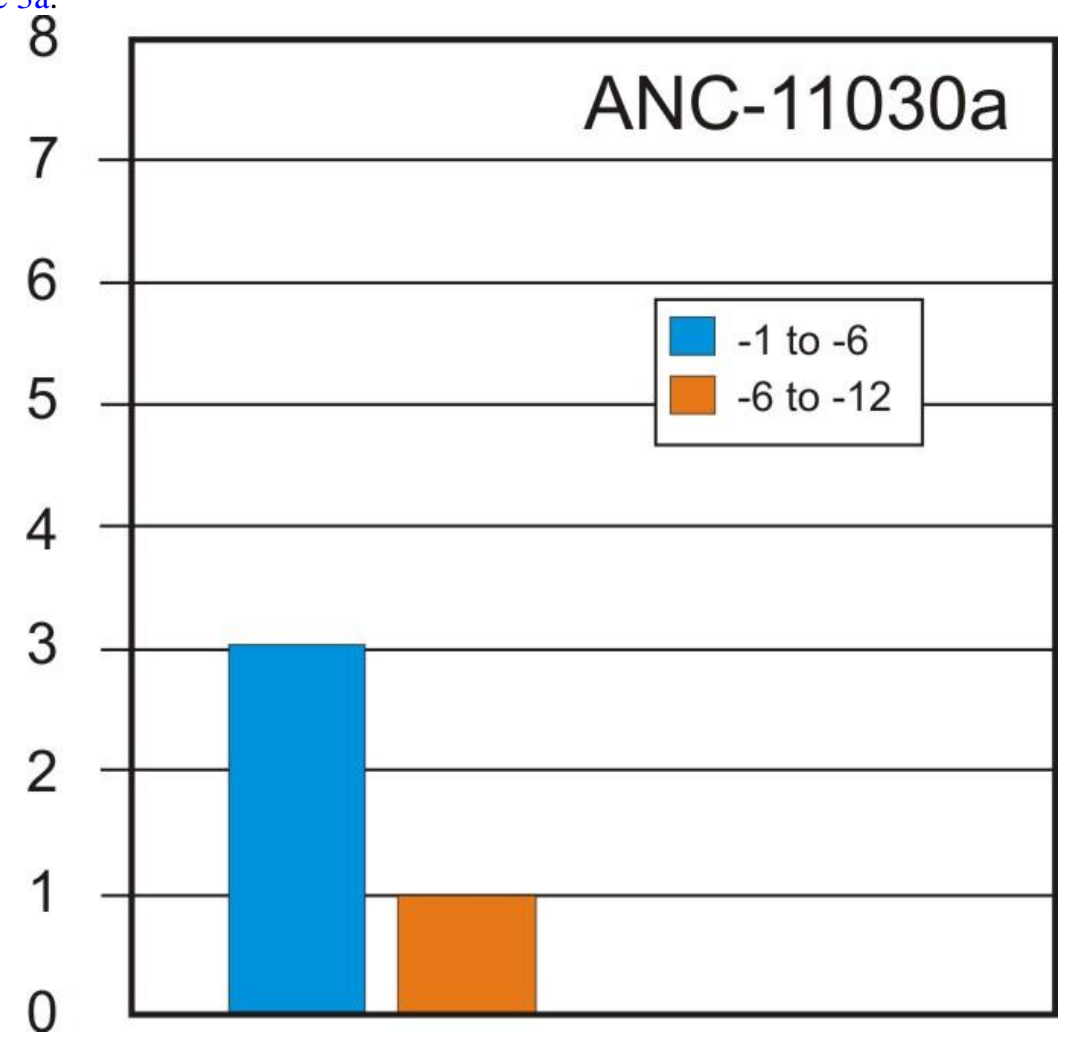


Table 3b (continuation). Laser ablation Hf isotope data for igneous dated zircons from Sierras Pampeanas of Argentina (location of samples in Fig. 1 and Table 1).

\begin{tabular}{|c|c|c|c|c|c|c|c|c|c|c|c|c|}
\hline Sample & Grain & $\begin{array}{c}\text { Age } \\
\text { (Ma) }\end{array}$ & ${ }^{176} \mathrm{Hf} /{ }^{177} \mathrm{Hf}$ & $\pm(2 \sigma)$ & ${ }^{176} \mathrm{Lu} /{ }^{177} \mathrm{Hf}$ & $\pm(2 \sigma)$ & ${ }^{176} \mathrm{Yb} /{ }^{177} \mathrm{Hf}$ & $\begin{array}{c}\text { Age } \\
\text { (Ma) }\end{array}$ & $\varepsilon \mathbf{H f}$ (today) & $\pm(2 \sigma)$ & $\varepsilon \mathbf{H f}(\mathbf{t})$ & $\mathbf{T}_{\mathrm{DM}} \mathbf{H f}$ \\
\hline \multirow[t]{8}{*}{ FAM-7086 } & $8 / 8$ & & & & & & & & & & & \\
\hline & FAM7086_1b & 489 & 0.282198 & 0.000043 & 0.002483 & 0.000073 & 0.076713 & 489 & -20.8 & 1.5 & -10.7 & 2.0 \\
\hline & FAM7086_5a & 489 & 0.282110 & 0.000035 & 0.002693 & 0.000144 & 0.088002 & 489 & -23.9 & 1.3 & -13.9 & 2.2 \\
\hline & FAM7086_3b & 489 & 0.281864 & 0.000066 & 0.004249 & 0.000176 & 0.150712 & 489 & -32.6 & 2.3 & -23.1 & 2.8 \\
\hline & FAM7086_3a & 489 & 0.281986 & 0.000030 & 0.004196 & 0.000377 & 0.119129 & 489 & -28.3 & 1.1 & -18.9 & 2.5 \\
\hline & FAM7086_4a & 489 & 0.282055 & 0.000065 & 0.002380 & 0.000074 & 0.072752 & 489 & -25.8 & 2.3 & -15.7 & 2.3 \\
\hline & FAM7086_2b & 489 & 0.282173 & 0.000037 & 0.002643 & 0.000108 & 0.085036 & 489 & -21.6 & 1.3 & -11.6 & 2.0 \\
\hline & FAM7086_2a & 489 & 0.282367 & 0.000035 & 0.001740 & 0.000072 & 0.074037 & 489 & -14.8 & 1.2 & -4.5 & 1.7 \\
\hline
\end{tabular}

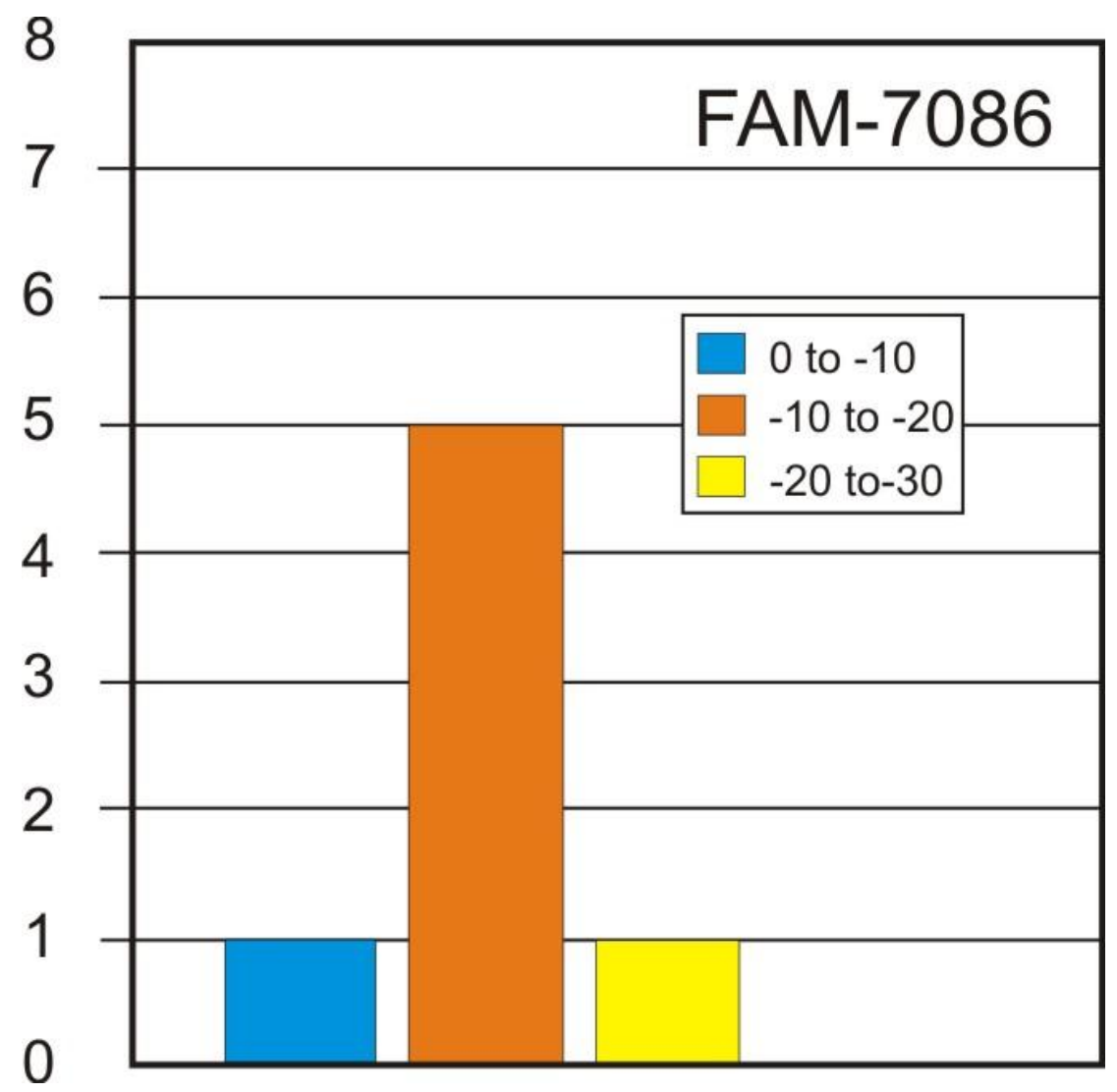


Table 3b (continuation). Laser ablation Hf isotope data for igneous dated zircons from Sierras Pampeanas of Argentina (location of samples in Fig. 1 and Table 1).

\begin{tabular}{|c|c|c|c|c|c|c|c|c|c|c|c|c|}
\hline Sample & Grain & $\begin{array}{c}\text { Age } \\
\text { (Ma) }\end{array}$ & ${ }^{176} \mathrm{Hf} /{ }^{177} \mathrm{Hf}$ & $\pm(2 \sigma)$ & ${ }^{176} \mathrm{Lu} /{ }^{177} \mathbf{H f}$ & $\pm(2 \sigma)$ & ${ }^{176} \mathrm{Yb} /{ }^{177} \mathbf{H f}$ & $\begin{array}{c}\text { Age } \\
\text { (Ma) }\end{array}$ & $\varepsilon \mathbf{H f}$ (today) & $\pm(2 \sigma)$ & $\varepsilon \mathbf{H f}(\mathbf{t})$ & $\mathbf{T}_{\mathrm{DM}} \mathbf{H f}$ \\
\hline \multirow{11}{*}{ SVF-577 } & $13 / 11$ & & & & & & & & & & & \\
\hline & SVF577_17a & 464 & 0.282324 & 0.000061 & 0.000581 & 0.000013 & 0.025969 & 464 & -16.3 & 2.2 & -6.1 & 1.7 \\
\hline & SVF577_15a & 464 & 0.282375 & 0.000057 & 0.000902 & 0.000040 & 0.037338 & 464 & -14.5 & 2.0 & -4.5 & 1.6 \\
\hline & SVF577_14a & 464 & 0.282149 & 0.000047 & 0.000619 & 0.000001 & 0.025898 & 472 & -22.5 & 1.7 & -12.2 & 2.1 \\
\hline & SVF577_13a & 464 & 0.282301 & 0.000046 & 0.000466 & 0.000016 & 0.020208 & 464 & -17.1 & 1.6 & -6.9 & 1.8 \\
\hline & SVF577_11a & 464 & 0.282335 & 0.000036 & 0.000260 & 0.000008 & 0.009712 & 464 & -15.9 & 1.3 & -5.7 & 1.7 \\
\hline & SVF577_10a & 464 & 0.282366 & 0.000046 & 0.000595 & 0.000037 & 0.020873 & 464 & -14.8 & 1.6 & -4.7 & 1.6 \\
\hline & SVF577_8a & 464 & 0.282334 & 0.000063 & 0.000434 & 0.000035 & 0.016921 & 464 & -16.0 & 2.2 & -5.8 & 1.7 \\
\hline & SVF577_7a & 464 & 0.282365 & 0.000067 & 0.000538 & 0.000037 & 0.021245 & 464 & -14.9 & 2.4 & -4.7 & 1.6 \\
\hline & SVF577_6a & 464 & 0.282380 & 0.000043 & 0.000445 & 0.000022 & 0.017711 & 464 & -14.3 & 1.5 & -4.1 & 1.6 \\
\hline & SVF577_1a & 464 & 0.282247 & 0.000059 & 0.000375 & 0.000019 & 0.011942 & 464 & -19.0 & 2.1 & -8.8 & 1.9 \\
\hline
\end{tabular}

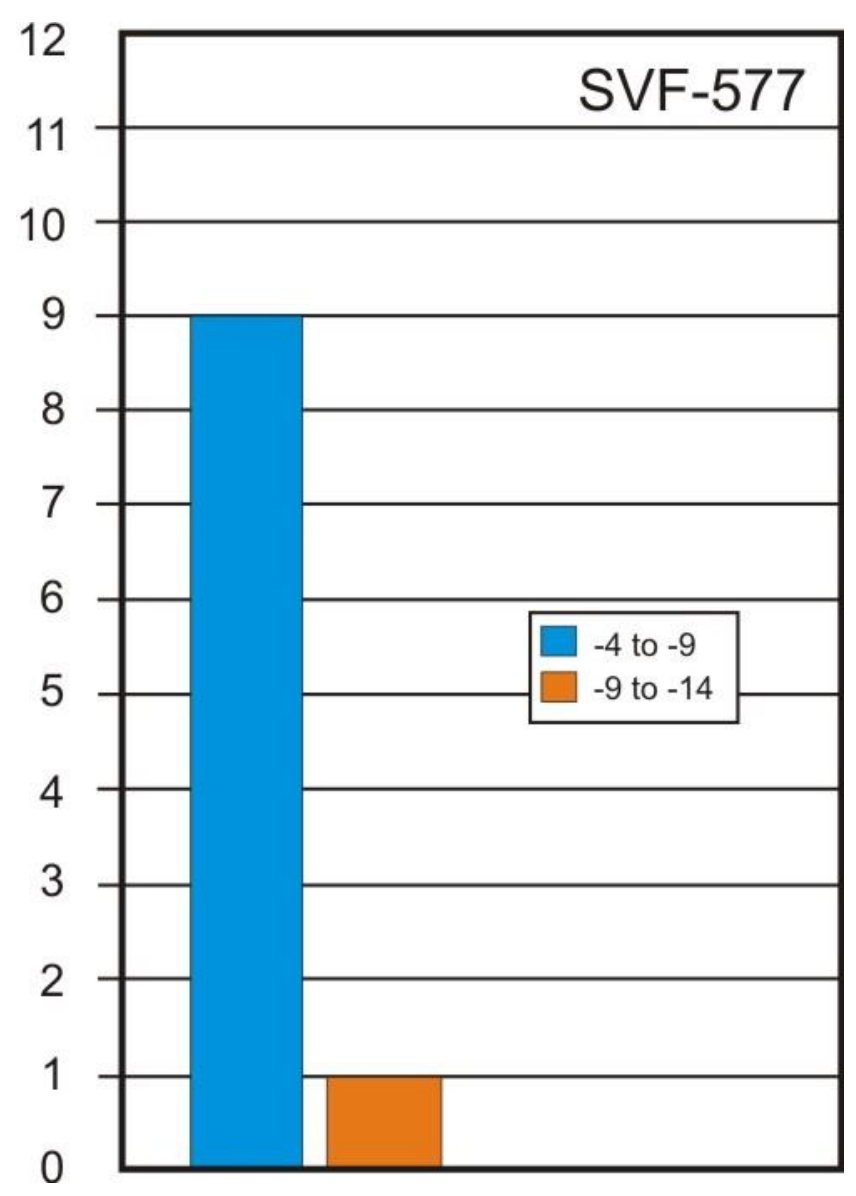


Table 3b (continuation). Laser ablation Hf isotope data for igneous dated zircons from Sierras Pampeanas of Argentina (location of samples in Fig. 1 and Table 1).

\begin{tabular}{|c|c|c|c|c|c|c|c|c|c|c|c|c|}
\hline Sample & Grain & $\begin{array}{c}\text { Age } \\
\text { (Ma) }\end{array}$ & ${ }^{176} \mathrm{Hf} /{ }^{177} \mathrm{Hf}$ & $\pm(2 \sigma)$ & ${ }^{176} \mathrm{Lu} /{ }^{177} \mathrm{Hf}$ & $\pm(2 \sigma)$ & ${ }^{176} \mathrm{Yb} /{ }^{177} \mathrm{Hf}$ & $\begin{array}{c}\text { Age } \\
\text { (Ma) }\end{array}$ & $\varepsilon \mathbf{H f}$ (today) & $\pm(2 \sigma)$ & $\varepsilon \mathbf{H f}(\mathbf{t})$ & $\mathbf{T}_{\mathrm{DM}} \mathbf{H f}$ \\
\hline \multicolumn{13}{|c|}{ Late-Middle Devonian granitic rocks (Achala batholith) } \\
\hline \multirow[t]{11}{*}{ ACH-140 } & $10 / 7$ & & & & & & & & & & & \\
\hline & ACH140_11a & 366 & 0.282264 & 0.000031 & 0.001794 & 0.000083 & 0.062771 & 366 & -18.4 & 1.1 & -10.7 & 2.0 \\
\hline & ACH140_10a & 366 & 0.282484 & 0.000023 & 0.000978 & 0.000051 & 0.051003 & 366 & -10.6 & 0.8 & -2.7 & 1.4 \\
\hline & ACH140_9a & 366 & 0.282468 & 0.000031 & 0.001216 & 0.000036 & 0.061520 & 366 & -11.2 & 1.1 & -3.4 & 1.5 \\
\hline & ACH140_7a & 366 & 0.282086 & 0.000052 & 0.003303 & 0.000076 & 0.110948 & 366 & -24.7 & 1.8 & -17.4 & 2.4 \\
\hline & ACH140_8a & 366 & 0.282380 & 0.000050 & 0.001339 & 0.000183 & 0.055740 & 366 & -14.3 & 1.8 & -6.5 & 1.7 \\
\hline & ACH140_6a & 366 & 0.282480 & 0.000030 & 0.000836 & 0.000031 & 0.043617 & 366 & -10.8 & 1.1 & -2.8 & 1.4 \\
\hline & ACH140_4a & 366 & 0.282128 & 0.000067 & 0.002252 & 0.000065 & 0.074003 & 366 & -23.2 & 2.4 & -15.6 & 2.3 \\
\hline & ACH140_5a & 366 & 0.282454 & 0.000025 & 0.000891 & 0.000017 & 0.044674 & 366 & -11.7 & 0.9 & -3.8 & 1.5 \\
\hline & ACH140_2b & 366 & 0.282434 & 0.000028 & 0.000893 & 0.000074 & 0.048033 & 366 & -12.4 & 1.0 & -4.5 & 1.5 \\
\hline & ACH140_1a & 366 & 0.282477 & 0.000025 & 0.000921 & 0.000061 & 0.048627 & 366 & -10.9 & 0.9 & -3.0 & 1.5 \\
\hline
\end{tabular}

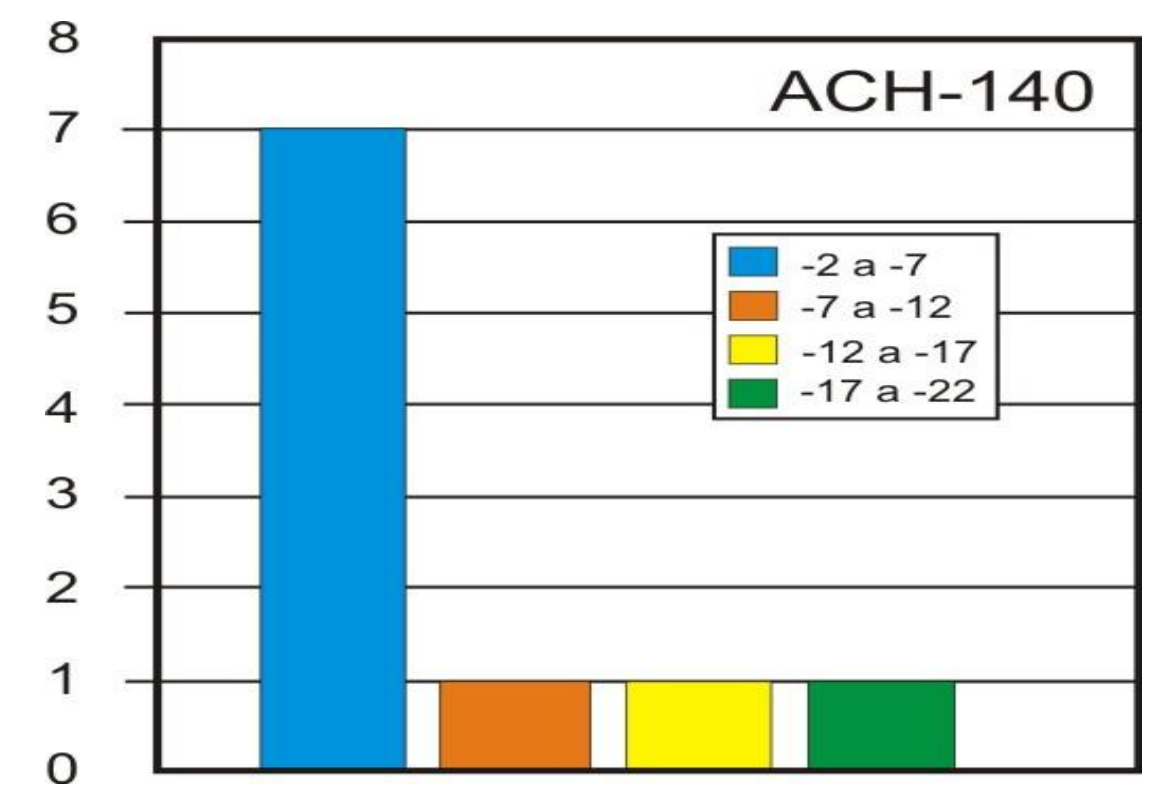


Table 3b (continuation). Laser ablation Hf isotope data for igneous dated zircons from Sierras Pampeanas of Argentina (location of samples in Fig. 1 and Table 1).

\begin{tabular}{|c|c|c|c|c|c|c|c|c|c|c|c|c|}
\hline Sample & Grain & $\begin{array}{c}\text { Age } \\
\text { (Ma) }\end{array}$ & ${ }^{176} \mathbf{H f} /{ }^{177} \mathbf{H f}$ & $\pm(2 s)$ & ${ }^{176} \mathrm{Lu} /{ }^{177} \mathbf{H f}$ & $\pm(2 s)$ & ${ }^{176} \mathbf{Y b} /{ }^{177} \mathbf{H f}$ & $\begin{array}{c}\text { Age } \\
\text { (Ma) }\end{array}$ & $\varepsilon \mathbf{H f}$ (today) & $\pm(2 s)$ & $\varepsilon \mathbf{H f}(\mathbf{t})$ & $\mathbf{T}_{\mathrm{DM}} \mathbf{H f}$ \\
\hline \multicolumn{13}{|c|}{ Early Carboniferous granitic rocks (Fiambalá, Velasco, Famatina and Zapata mountain ranges). } \\
\hline \multirow[t]{8}{*}{ FIA-17 } & $8 / 6$ & & & & & & & & & & & \\
\hline & FIA17_6b & 322 & 0.282477 & 0.000074 & 0.000544 & 0.000002 & 0.026722 & 322 & -10.9 & 2.6 & -3.9 & 1.5 \\
\hline & FIA17_4b & 322 & 0.282149 & 0.000047 & 0.000619 & 0.000001 & 0.025898 & 322 & -22.5 & 1.7 & -15.5 & 2.2 \\
\hline & FIA17_4a & 322 & 0.282493 & 0.000046 & 0.001762 & 0.000147 & 0.097517 & 322 & -10.3 & 1.6 & -3.5 & 1.4 \\
\hline & FIA17_3b & 322 & 0.282432 & 0.000067 & 0.000916 & 0.000027 & 0.045564 & 322 & -12.5 & 2.4 & -5.5 & 1.6 \\
\hline & FIA17_3a & 322 & 0.282359 & 0.000068 & 0.000627 & 0.000019 & 0.030277 & 322 & -15.1 & 2.4 & -8.0 & 1.7 \\
\hline & FIA17_1b & 322 & 0.282469 & 0.000064 & 0.000677 & 0.000011 & 0.034428 & 322 & -11.2 & 2.3 & -4.2 & 1.5 \\
\hline & FIA17_1a & 322 & 0.282445 & 0.000061 & 0.000557 & 0.000014 & 0.027907 & 322 & -12.0 & 2.2 & -5.0 & 1.6 \\
\hline
\end{tabular}

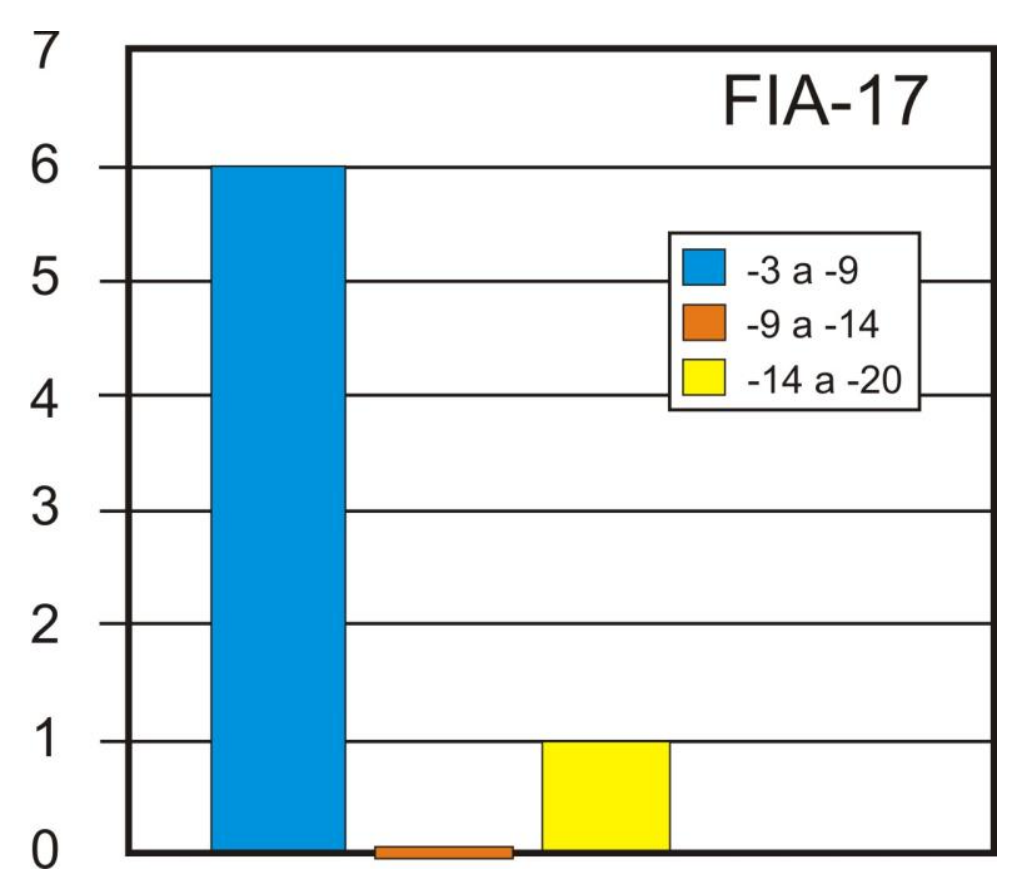


Table 3b (continuation). Laser ablation Hf isotope data for igneous dated zircons from Sierras Pampeanas of Argentina (location of samples in Fig. 1 and Table 1).

\begin{tabular}{|c|c|c|c|c|c|c|c|c|c|c|c|c|}
\hline Sample & Grain & $\begin{array}{l}\text { Age } \\
\text { (Ma) }\end{array}$ & ${ }^{176} \mathrm{Hf} /{ }^{177} \mathrm{Hf}$ & $\pm(2 s)$ & ${ }^{176} \mathrm{Lu} /{ }^{177} \mathrm{Hf}$ & $\pm(2 s)$ & ${ }^{176} \mathrm{Yb} /{ }^{177} \mathrm{Hf}$ & $\begin{array}{l}\text { Age } \\
\text { (Ma) }\end{array}$ & $\boldsymbol{\varepsilon H f}$ (today) & $\pm(2 s)$ & $\varepsilon \mathbf{H f}(\mathrm{t})$ & $\mathbf{T}_{\mathrm{DM}} \mathrm{Hf}$ \\
\hline \multirow[t]{8}{*}{ HUA-12 } & $7 / 5$ & & & & & & & & & & & \\
\hline & HUA12_6a & 357 & 0.282523 & 0.000029 & 0.001206 & 0.000169 & 0.059043 & 357 & -9.3 & 1.3 & -1.6 & 1.4 \\
\hline & HUA12_5b & 357 & 0.282503 & 0.000051 & 0.001274 & 0.000072 & 0.065866 & 357 & -10.0 & 1.8 & -2.4 & 1.4 \\
\hline & HUA12_5a & 357 & 0.282303 & 0.000069 & 0.002333 & 0.000165 & 0.080259 & 357 & -17.1 & 2.4 & -9.7 & 1.9 \\
\hline & HUA12_4a & 357 & 0.282471 & 0.000040 & 0.000989 & 0.000011 & 0.049964 & 357 & -11.1 & 1.4 & -3.4 & 1.5 \\
\hline & HUA12_3a & 357 & 0.282405 & 0.000038 & 0.001637 & 0.000033 & 0.084079 & 357 & -13.4 & 1.3 & -5.9 & 1.6 \\
\hline & HUA12_2a & 357 & 0.282575 & 0.000070 & 0.000736 & 0.000022 & 0.038552 & 357 & -7.4 & 2.5 & 0.3 & 1.3 \\
\hline & HUA12_1a & 357 & 0.282469 & 0.000059 & 0.000771 & 0.000044 & 0.041285 & 357 & -11.2 & 2.1 & -3.4 & 1.5 \\
\hline
\end{tabular}

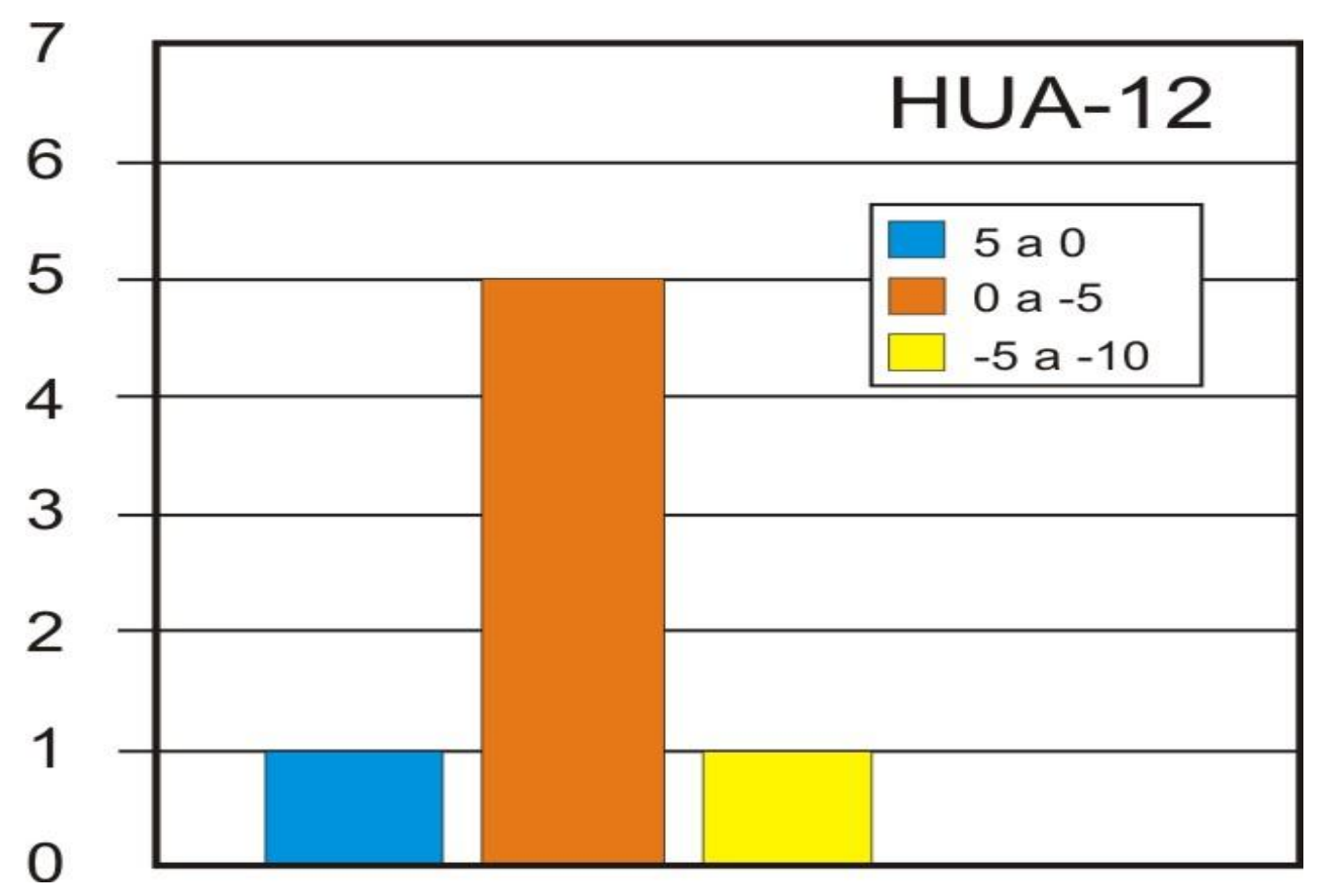


Table 3b (continuation). Laser ablation Hf isotope data for igneous dated zircons from Sierras Pampeanas of Argentina (location of samples in Fig. 1 and Table 1).

\begin{tabular}{|c|c|c|c|c|c|c|c|c|c|c|c|c|}
\hline Sample & Grain & $\begin{array}{c}\text { Age } \\
\text { (Ma) }\end{array}$ & ${ }^{176} \mathrm{Hf} /{ }^{177} \mathrm{Hf}$ & $\pm(2 \sigma)$ & ${ }^{176} \mathrm{Lu} /{ }^{177} \mathrm{Hf}$ & $\pm(2 \sigma)$ & ${ }^{176} \mathrm{Yb} /{ }^{177} \mathrm{Hf}$ & $\begin{array}{c}\text { Age } \\
\text { (Ma) }\end{array}$ & $\varepsilon \mathbf{H} \mathbf{f}_{\text {(today) }}$ & $\pm(2 \sigma)$ & $\varepsilon \mathbf{H f}(\mathbf{t})$ & $\begin{array}{c}\mathbf{T}_{\text {DM }} \\
\text { Hf } \\
\end{array}$ \\
\hline \multirow[t]{12}{*}{ FAM-177 } & $11 / 9$ & & & & & & & & & & & \\
\hline & FAM_177_3b & 353 & 0.282605 & 0.000055 & 0.001347 & 0.000027 & 0.063763 & 353 & -6.4 & 2.0 & 1.2 & 1.2 \\
\hline & FAM_177_6b & 353 & 0.282666 & 0.000037 & 0.002280 & 0.000232 & 0.098271 & 353 & -4.2 & 1.3 & 3.1 & 1.04 \\
\hline & FAM_177_6a & 353 & 0.282493 & 0.000054 & 0.003096 & 0.000118 & 0.098314 & 353 & -10.3 & 1.9 & -3.2 & 1.5 \\
\hline & FAM_177_5b & 353 & 0.282655 & 0.000040 & 0.001772 & 0.000030 & 0.088599 & 353 & -4.6 & 1.4 & 2.8 & 1.1 \\
\hline & FAM_177_5a & 353 & 0.282566 & 0.000054 & 0.003304 & 0.000244 & 0.127620 & 353 & -7.7 & 1.9 & -0.7 & 1.3 \\
\hline & FAM_177_4b & 353 & 0.282607 & 0.000031 & 0.001263 & 0.000027 & 0.059873 & 353 & -6.3 & 1.1 & 1.3 & 1.2 \\
\hline & FAM_177_4a & 353 & 0.282667 & 0.000035 & 0.002556 & 0.000214 & 0.121723 & 353 & -4.2 & 1.2 & 3.1 & 1.0 \\
\hline & FAM_177_3a & 353 & 0.282651 & 0.000038 & 0.002223 & 0.000168 & 0.105691 & 353 & -4.7 & 1.3 & 2.6 & 1.1 \\
\hline & FAM_177_2a & 353 & 0.282632 & 0.000052 & 0.001272 & 0.000140 & 0.057944 & 353 & -5.4 & 1.9 & 2.2 & 1.1 \\
\hline & FAM_177_1b & 353 & 0.282628 & 0.000031 & 0.001679 & 0.000085 & 0.079175 & 353 & -5.6 & 1.1 & 1.9 & 1.1 \\
\hline & FAM_177_1a & 353 & 0.282716 & 0.000034 & 0.002703 & 0.000258 & 0.131327 & 353 & -2.4 & 1.2 & 4.8 & 0.9 \\
\hline
\end{tabular}

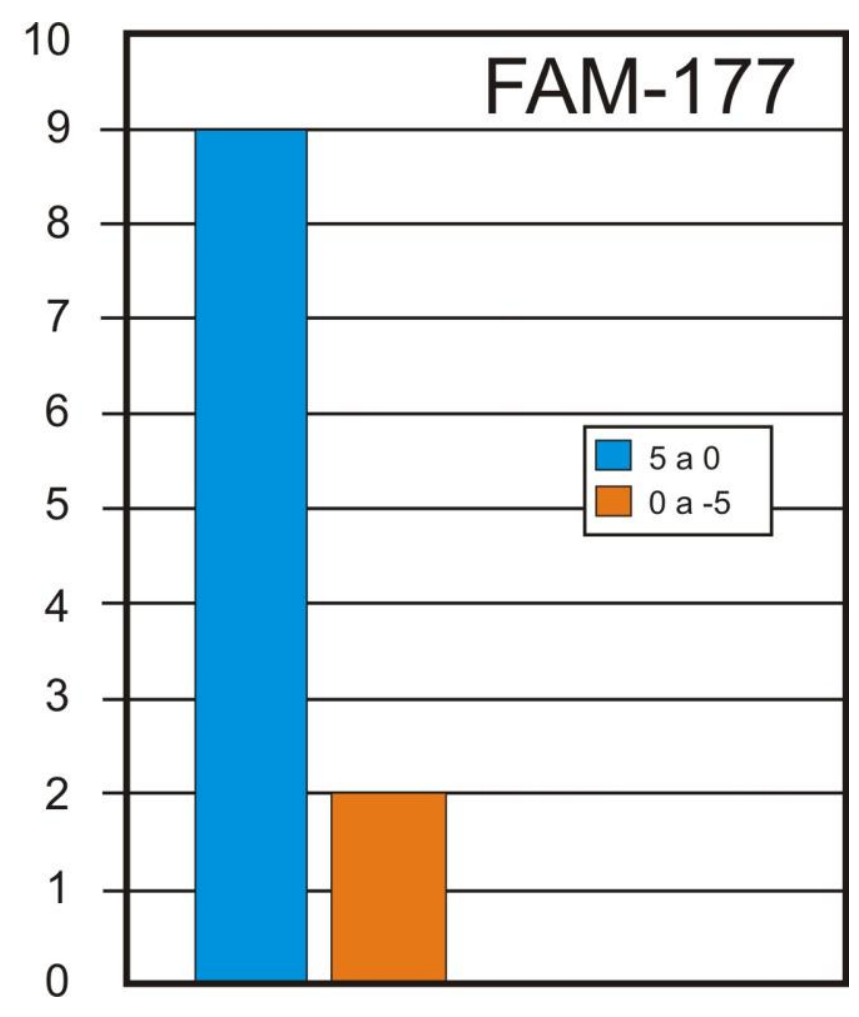


Table 3b (continuation). Laser ablation Hf isotope data for igneous dated zircons from Sierras Pampeanas of Argentina (location of samples in Fig. 1 and Table 1).

\begin{tabular}{|c|c|c|c|c|c|c|c|c|c|c|c|c|}
\hline Sample & Grain & $\begin{array}{c}\text { Age } \\
\text { (Ma) }\end{array}$ & ${ }^{176} \mathrm{Hf} /{ }^{177} \mathrm{Hf}$ & $\pm(2 \sigma)$ & ${ }^{176} \mathrm{Lu} /{ }^{177} \mathrm{Hf}$ & $\pm(2 \sigma)$ & ${ }^{176} \mathrm{Yb} /{ }^{177} \mathrm{Hf}$ & $\begin{array}{c}\text { Age } \\
\text { (Ma) }\end{array}$ & $\varepsilon \mathbf{H} \mathbf{f}_{\text {(today) }}$ & $\pm(2 \sigma)$ & $\varepsilon \mathbf{H f}(\mathbf{t})$ & $\mathbf{T}_{\mathrm{DM}} \mathrm{Hf}$ \\
\hline \multirow[t]{13}{*}{ ZAP-33 } & $12 / 11$ & & & & & & & & & & & \\
\hline & ZAP_33_12a & 340 & 0.282409 & 0.000024 & 0.000482 & 0.000017 & 0.022801 & 340 & -13.3 & 0.9 & -5.9 & 1.6 \\
\hline & ZAP_33_11a & 340 & 0.282409 & 0.000031 & 0.000685 & 0.000014 & 0.031634 & 340 & -13.3 & 1.1 & -5.9 & 1.6 \\
\hline & ZAP_33_10a & 340 & 0.282424 & 0.000023 & 0.000577 & 0.000005 & 0.026810 & 340 & -12.8 & 0.8 & -5.3 & 1.6 \\
\hline & ZAP_33_9a & 340 & 0.282379 & 0.000023 & 0.000926 & 0.000024 & 0.044627 & 340 & -14.4 & 0.8 & -7.0 & 1.7 \\
\hline & ZAP_33_8a & 340 & 0.282407 & 0.000044 & 0.000616 & 0.000009 & 0.031501 & 340 & -13.4 & 1.6 & -5.9 & 1.6 \\
\hline & ZAP_33_7b & 340 & 0.282396 & 0.000035 & 0.000576 & 0.000022 & 0.027877 & 340 & -13.8 & 1.2 & -6.3 & 1.7 \\
\hline & ZAP_33_6a & 340 & 0.282196 & 0.000034 & 0.000602 & 0.000007 & 0.027530 & 377 & -20.8 & 1.2 & -13.4 & 2.1 \\
\hline & ZAP_33_5a & 340 & 0.282438 & 0.000024 & 0.000453 & 0.000002 & 0.020572 & 340 & -12.3 & 0.9 & -4.8 & 1.6 \\
\hline & ZAP_33_3b & 340 & 0.282447 & 0.000032 & 0.000851 & 0.000009 & 0.036220 & 340 & -12.0 & 1.1 & -4.6 & 1.5 \\
\hline & ZAP_33_3a & 340 & 0.282431 & 0.000025 & 0.001165 & 0.000026 & 0.048962 & 340 & -12.5 & 0.9 & -5.2 & 1.6 \\
\hline & ZAP_33_2a & 340 & 0.282394 & 0.000028 & 0.000615 & 0.000017 & 0.028751 & 340 & -13.8 & 1.0 & -6.4 & 1.7 \\
\hline & ZAP_33_1a & 340 & 0.282401 & 0.000040 & 0.001311 & 0.000099 & 0.039749 & 340 & -13.6 & 1.4 & -6.3 & 1.6 \\
\hline
\end{tabular}

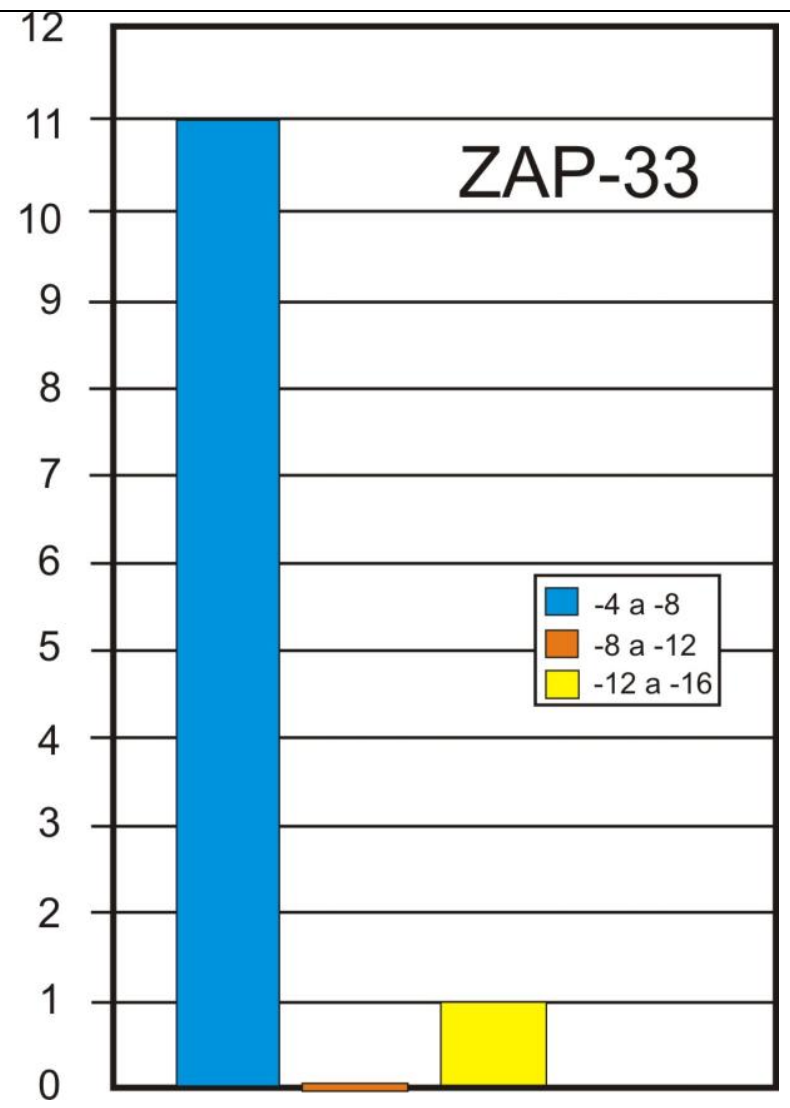


Table 4.

Whole-rock Nd isotopes for Early-Middle Ordovician metaluminous plutonic rocks

\begin{tabular}{|c|c|c|c|c|c|c|c|c|c|}
\hline Sample & Litology & Ages & $\underset{(p p m)}{\text { Sm }}$ & $\begin{array}{c}\text { Nd } \\
(\text { ppm })\end{array}$ & ${ }^{147} \mathrm{Sm} /{ }^{144} \mathrm{Nd}$ & $\left({ }^{143} \mathrm{Nd} /{ }^{144} \mathrm{Nd}\right)_{\text {today }}$ & $\left({ }^{143} \mathrm{Nd} /{ }^{144} \mathrm{Nd}\right) \mathrm{t}$ & $\varepsilon N d(t)$ & $\begin{array}{l}\mathbf{T}_{\mathbf{D M}}^{\dagger} \\
(\mathbf{G a})\end{array}$ \\
\hline VCA-7037 & Granodiorite & 473 & 1.60 & 6.20 & 0.1592 & 0.512226 & 0.511733 & -5.8 & 1.7 \\
\hline VCA-7038 & Granodiorite & 473 & 3.70 & 20.2 & 0.1098 & 0.512113 & 0.511773 & -5.0 & 1.6 \\
\hline VCA-7040 & Granodiorite & 473 & 4.20 & 22.3 & 0.1144 & 0.512112 & 0.511758 & -5.3 & 1.6 \\
\hline VCA-7039 & Granodiorite & 473 & 4.90 & 22.3 & 0.1323 & 0.512191 & 0.511781 & -4.8 & 1.6 \\
\hline FAM-7086 & Tonalite & 473 & 14.2 & 59.4 & 0.1445 & 0.512172 & 0.511724 & -5.9 & 1.7 \\
\hline FAM-7083 & Monzogranite & 473 & 7.70 & 36.6 & 0.1264 & 0.512270 & 0.511878 & -2.9 & 1.4 \\
\hline RLC-243 & Granodiorite & 473 & 5.50 & 28.3 & 0.1172 & 0.512122 & 0.511759 & -5.3 & 1.6 \\
\hline GUA-253 & Tonalite & 473 & 5.00 & 20.9 & 0.1455 & 0.512214 & 0.511763 & -5.2 & 1.6 \\
\hline GUA-252 & Aplite & 473 & 1.80 & 5.40 & 0.1983 & 0.512370 & 0.511756 & -5.3 & 1.6 \\
\hline MIS-259 & Tonalite & 473 & 8.80 & 40.0 & 0.1336 & 0.512200 & 0.511786 & -4.7 & 1.6 \\
\hline PUL-244 & Granodiorite & 473 & 7.30 & 36.5 & 0.1213 & 0.512183 & 0.511807 & -4.3 & 1.5 \\
\hline ELE-206 & Monzogranite & 473 & 6.10 & 26.0 & 0.1424 & 0.512173 & 0.511732 & -5.8 & 1.7 \\
\hline NAC-257 & Monzogranite & 473 & 3.80 & 18.4 & 0.1264 & 0.512159 & 0.511767 & -5.1 & 1.6 \\
\hline OLT-279 & Monzogranite & 473 & 4.90 & 19.1 & 0.1560 & 0.512221 & 0.511738 & -5.7 & 1.6 \\
\hline OLT-282 & Monzogranite & 473 & 5.20 & 24.2 & 0.1292 & 0.512142 & 0.511742 & -5.6 & 1.6 \\
\hline PAS-272 & Granodiorite & 473 & 5.50 & 27.5 & 0.1198 & 0.512119 & 0.511748 & -5.5 & 1.6 \\
\hline SVF-577 & Hbl-rich Gabbro & 473 & 10.1 & 38.7 & 0.1582 & 0.512242 & 0.511752 & -5.4 & 1.6 \\
\hline ANC-11022 & Monzogranite & 473 & 3.90 & 16.8 & 0.1412 & 0.512212 & 0.511779 & -3.3 & 1.5 \\
\hline ANC-11030a & Tonalite & 473 & 6.00 & 30.2 & 0.1198 & 0.512233 & 0.511863 & -5.0 & 1.6 \\
\hline Average & & 473 & & & & & 0.511770 & -5.1 & 1.7 \\
\hline
\end{tabular}

Age average (473 Ma) was obtained from range of values (484-463 Ma) reported by Dahlquist et al. (2008). Average Nd isotopic composition excludes a few extreme values below -7.0 obtained from S-type granites. $\left({ }^{143} \mathrm{Nd} /{ }^{144} \mathrm{Nd}\right) \mathrm{t}$ CHUR $=0.512029$, with $\mathrm{t}=473 \mathrm{Ma}$.

NOTES: 1. Early-Middle Ordovician data from Pankhurst et al. (1998, 2000) and Dahlquist et al. (2008, 2010). ANC-11030a from Dahlquist et al. (2012), Early Carboniferous data from Dahlquist et al. (2010), and Middle-Late Devonian data from this work, excepting ACH-5, ACH-15, ACH-23, ACH-25 (Rapela et al., 2008b). 2. The decay constants used in the calculations are the values $\lambda^{147} \mathrm{Sm}=6.54 \times 10^{-12}$ year ${ }^{-1}$ recommended by the IUGS Subcommision for Geochronology (Steiger and Jaëger, 1977). Epsilon-Nd ( $\varepsilon N d$ ) values calculated using the following CHUR parameters (Goldstein et al., 1984; Jacobsen and Wasserburg, 1980): $\left({ }^{143} \mathrm{Nd} /{ }^{144} \mathrm{Nd}\right.$ )today $=0.512638 ;\left({ }^{143} \mathrm{Sm} /{ }^{144} \mathrm{Nd}\right)$ today $=$ 0.1967. $\mathrm{t}=$ time used for the calculation of the isotopic initial ratios.

${ }^{\top} \mathrm{T}_{\mathrm{DM}}=$ calculated according to De Paolo et al. (1991).

${ }^{\S}$ VCA-6017 = SPB-9.

${ }^{\#} \mathrm{CHI}-7$ produce an irreal $\mathrm{T}_{\mathrm{DM}}$ value of $-1.4 \mathrm{Ga}$. 
Table 4 (continuation).

Whole-rock Nd isotopes for Late-Middle Devonian granitic rocks

\begin{tabular}{|c|c|c|c|c|c|c|c|c|c|}
\hline Sample & Litology & Age & $\underset{(p p m)}{\mathbf{S m}}$ & $\begin{array}{c}\text { Nd } \\
(p p m)\end{array}$ & ${ }^{147} \mathrm{Sm} /{ }^{144} \mathrm{Nd}$ & $\left({ }^{143} \mathrm{Nd} /{ }^{144} \mathrm{Nd}\right)_{\text {today }}$ & $\left({ }^{143} \mathrm{Nd} /{ }^{144} \mathrm{Nd}\right) \mathrm{t}$ & $\varepsilon N d(t)$ & $\begin{array}{l}\mathbf{T}_{\mathbf{D M}}{ }^{\dagger} \\
\text { (Ga) }\end{array}$ \\
\hline DAL-1 & Felsic Granodiorite & 369 & 11.5 & 57.7 & 0.1203 & 0.512200 & 0.511910 & -5.0 & 1.5 \\
\hline $\mathrm{ACH}-140$ & Monzogranite & 369 & 5.50 & 26.8 & 0.1248 & 0.512216 & 0.511915 & -4.9 & 1.5 \\
\hline NPE-6 & Monzogranite & 369 & 8.80 & 43.3 & 0.1223 & 0.512152 & 0.511858 & -6.0 & 1.6 \\
\hline NPE-14 & Monzogranite & 369 & 10.2 & 55.5 & 0.1112 & 0.512112 & 0.511843 & -6.3 & 1.6 \\
\hline NPE-10 & Bt-Ap bodies & 369 & 159 & 709. & 0.1358 & 0.512202 & 0.511875 & -5.7 & 1.6 \\
\hline NPE-5 & Bt-rich granite & 369 & 17.6 & 87.6 & 0.1214 & 0.512148 & 0.511855 & -6.0 & 1.6 \\
\hline $\mathrm{ACH}-154$ & Felsic Granodiorite & 369 & 13.6 & 97.9 & 0.0841 & 0.512033 & 0.511830 & -6.5 & 1.6 \\
\hline ACH-155 & Monzogranite & 369 & 8.90 & 50.2 & 0.1066 & 0.512104 & 0.511849 & -6.2 & 1.6 \\
\hline $\mathrm{ACH}-5$ & Monzogranite & 369 & 3.70 & 19.7 & 0.1128 & 0.512233 & 0.511961 & -4.0 & 1.4 \\
\hline $\mathrm{ACH}-25$ & Monzogranite & 369 & 6.20 & 32.5 & 0.1159 & 0.512239 & 0.511960 & -4.0 & 1.4 \\
\hline ACH-23 & Tonalite & 369 & 6.40 & 39.0 & 0.1000 & 0.512341 & 0.512100 & -1.2 & 1.2 \\
\hline ACH-15 & Tonalite & 369 & 7.10 & 35.9 & 0.1191 & 0.512354 & 0.512067 & -1.9 & 1.3 \\
\hline Average & & 369 & & & & & 0.511919 & -4.8 & 1.5 \\
\hline
\end{tabular}

Age average (369 Ma) was obtained from ages reported in Table 1. Average excluding the tonalites, ACH-23 and 15 (see discussion in the text). ACH-155, NPE-5, 6, 10, and 14 from Dahlquist et al. (submitted JSAES). 
Table 4 (continuation).

Whole-rock Nd isotopes for Early Carboniferous granitic rocks

\begin{tabular}{|c|c|c|c|c|c|c|c|c|c|}
\hline Sample & Lithology & Age & $\begin{array}{c}\text { Sm } \\
(p p m)\end{array}$ & $\begin{array}{c}\text { Nd } \\
(p p m)\end{array}$ & ${ }^{147} \mathrm{Sm} /{ }^{144} \mathrm{Nd}$ & $\left({ }^{143} \mathrm{Nd} /{ }^{144} \mathrm{Nd}\right)_{\text {today }}$ & $\left({ }^{143} \mathrm{Nd} /{ }^{144} \mathrm{Nd}\right) \mathrm{t}$ & $\varepsilon N d(t)$ & $\begin{array}{l}\mathbf{T}_{\mathrm{DM}}^{\dagger} \\
(\mathbf{G a})\end{array}$ \\
\hline FIA-3 & Monzogranite & 341 & 12.1 & 67.1 & 0.1090 & 0.512351 & 0.512108 & -1.8 & 1.3 \\
\hline FIA-8 & Monzogranite & 341 & 11.9 & 64.0 & 0.1124 & 0.512320 & 0.512069 & -2.5 & 1.3 \\
\hline FIA-17 & Monzogranite & 341 & 12.1 & 51.5 & 0.1420 & 0.512434 & 0.512117 & -1.6 & 1.2 \\
\hline FIA-18 & Monzogranite & 341 & 12.5 & 52.0 & 0.1453 & 0.512458 & 0.512134 & -1.3 & 1.2 \\
\hline FIA-22 & Monzogranite & 341 & 11.2 & 61.7 & 0.1097 & 0.512406 & 0.512161 & -0.7 & 1.2 \\
\hline HUA-4 & Monzogranite & 341 & 4.60 & 20.1 & 0.1383 & 0.512338 & 0.512029 & -3.3 & 1.4 \\
\hline HUA-6 & Monzogranite & 341 & 10.2 & 46.5 & 0.1326 & 0.512365 & 0.512069 & -2.5 & 1.3 \\
\hline HUA-7 & Monzogranite & 341 & 9.80 & 43.6 & 0.1359 & 0.512335 & 0.512032 & -3.3 & 1.4 \\
\hline HUA-12 & Monzogranite & 341 & 10.5 & 49.1 & 0.1293 & 0.512352 & 0.512063 & -2.6 & 1.3 \\
\hline HUA-13 & Monzogranite & 341 & 9.20 & 44.8 & 0.1241 & 0.512318 & 0.512041 & -3.1 & 1.4 \\
\hline SBP-6 & Monzogranite & 341 & 17.0 & 82.1 & 0.1252 & 0.512234 & 0.511955 & -4.8 & 1.5 \\
\hline SBP-9 ${ }^{\dagger}$ & Monzogranite & 341 & 9.60 & 47.5 & 0.1222 & 0.512395 & 0.512122 & -1.5 & 1.2 \\
\hline SBP-10 & Monzogranite & 341 & 16.8 & 73.9 & 0.1374 & 0.512537 & 0.512230 & 0.6 & 1.1 \\
\hline SBP-15 & Monzogranite & 341 & 11.1 & 59.5 & 0.1128 & 0.512365 & 0.512113 & -1.7 & 1.2 \\
\hline ZAP-26 & Monzogranite & 341 & 17.1 & 92.3 & 0.1120 & 0.512258 & 0.512008 & -3.7 & 1.4 \\
\hline ZAP-27 & Monzogranite & 341 & 18.6 & 69.6 & 0.1616 & 0.512430 & 0.512069 & -2.5 & 1.3 \\
\hline ZAP-29 & Monzogranite & 341 & 15.1 & 64.5 & 0.1415 & 0.512366 & 0.512050 & -2.9 & 1.3 \\
\hline ZAP-33 & Monzogranite & 341 & 9.70 & 46.3 & 0.1266 & 0.512306 & 0.512023 & -3.4 & 1.4 \\
\hline CHI-7 & Monzogranite & 341 & 6.62 & 14.8 & 0.2700 & 0.512663 & 0.512060 & -2.7 & 1.3 \\
\hline FAM-177 & Monzogranite & 341 & 9.47 & 53.5 & 0.1070 & 0.512403 & 0.512164 & -0.7 & 1.2 \\
\hline Average & & 341 & & & & & 0.512081 & -2.3 & 1.3 \\
\hline
\end{tabular}

Age average (341 Ma) was obtained from ages reported in Table 1. 
Table 5.

Major and trace element data for the plutonic rocks with $\mathrm{Hf}$ and $\mathrm{Nd}$ isotopes data (location of samples in Fig. 1 and Table 1).

\begin{tabular}{|c|c|c|c|c|c|c|c|c|c|c|c|c|c|}
\hline \multirow[b]{2}{*}{ Samples } & \multicolumn{3}{|c|}{ Early-Middle Ordovician Plutonic Rocks } & \multicolumn{4}{|c|}{ Middle-Late Devonian Plutonic Rocks } & \multicolumn{6}{|c|}{ Early Carboniferous Plutonic Rocks } \\
\hline & SVF-577 & FAM-7086 & ANC-11030a & ACH-140 & DAL-1 & NPE-10 & NPE-14 & FIA-17 & HUA-12 & CHI-17 & FAM-177 & SBP-09 & ZAP-33 \\
\hline Lithology & $\mathrm{Gb}$ & Tn & $\mathrm{Tn}$ & Mzg & $\begin{array}{c}\text { Felsic } \\
\text { Gda }\end{array}$ & $\begin{array}{l}\text { Bt-Ap-rich } \\
\text { bodies }\end{array}$ & Mzg & Mzg & Mzg & Mzg & Mzg & Mzg & Mzg \\
\hline \multicolumn{14}{|l|}{$w t . \%$} \\
\hline $\mathrm{SiO}_{2}$ & 42.58 & 62.73 & 60.92 & 73.07 & 69.16 & 32.83 & 70.98 & 74.50 & 73.30 & 74.20 & 75.05 & 71.83 & 71.86 \\
\hline $\mathrm{TiO}_{2}$ & 1.28 & 0.64 & 0.80 & 0.22 & 0.49 & 2.77 & 0.36 & 0.07 & 0.19 & 0.03 & 0.21 & 0.38 & 0.25 \\
\hline $\mathrm{Fe}_{2} \mathrm{O}_{3}{ }^{\mathrm{t}}$ & 5.19 & 6.48 & 5.51 & 2.08 & 0.00 & 0.00 & 0.00 & 1.45 & 2.27 & 1.05 & 2.13 & 3.09 & 2.41 \\
\hline $\mathrm{FeO}^{\mathrm{t}}$ & 9.01 & N.D. ${ }^{\dagger}$ & N.D. ${ }^{\dagger}$ & N.D. & 3.24 & 17.02 & 2.00 & N.D. & N.D. & N.D. & N.D. & N.D. & N.D. \\
\hline $\mathrm{MnO}$ & 0.23 & 0.15 & 0.13 & 0.04 & 0.13 & 0.41 & 0.04 & 0.02 & 0.05 & 0.04 & 0.03 & 0.05 & 0.04 \\
\hline $\mathrm{MgO}$ & 6.87 & 2.22 & 1.42 & 0.39 & 0.74 & 5.03 & 0.50 & 0.03 & 0.15 & 0.05 & 0.18 & 0.33 & 0.19 \\
\hline $\mathrm{CaO}$ & 12.25 & 3.23 & 4.86 & 0.93 & 1.08 & 6.67 & 0.71 & 0.64 & 0.84 & 0.49 & 0.83 & 1.15 & 1.06 \\
\hline $\mathrm{Na}_{2} \mathrm{O}$ & 1.69 & 3.61 & 3.95 & 2.71 & 3.62 & 0.20 & 3.07 & 3.29 & 3.18 & 3.71 & 3.59 & 3.29 & 3.06 \\
\hline $\mathrm{K}_{2} \mathrm{O}$ & 0.52 & 2.76 & 1.84 & 5.32 & 4.33 & 7.05 & 5.40 & 4.92 & 5.19 & 5.08 & 5.03 & 5.39 & 5.70 \\
\hline $\mathrm{P}_{2} \mathrm{O}_{5}$ & 0.21 & 0.05 & 0.26 & 0.28 & 0.43 & 5.39 & 0.30 & 0.02 & 0.14 & 0.02 & 0.04 & 0.21 & 0.07 \\
\hline Total & 99.86 & 100.06 & 98.64 & 99.76 & 99.24 & $92.71^{*}$ & 99.23 & 98.58 & 100.33 & 99.16 & 99.94 & 99.99 & 99.47 \\
\hline \multicolumn{14}{|l|}{ ppm } \\
\hline Cs & 0.2 & 10.1 & 21.3 & 12.3 & 33.2 & 102.5 & 9.5 & 10.1 & 31.7 & 16.2 & 1.5 & 31.1 & 11.5 \\
\hline $\mathrm{Rb}$ & 3.3 & 176 & 78 & 330 & 551 & 1500.2 & 345.9 & 650 & 450 & 716 & 107 & 470 & 372 \\
\hline $\mathrm{Sr}$ & 205 & 122 & 405 & 68 & 65.8 & 12.7 & 82.3 & 9 & 60 & 9 & 65 & 63 & 74 \\
\hline $\mathrm{Ba}$ & 70 & 152 & 282 & 175 & 154.7 & 148.3 & 334.1 & 31 & 251 & 16 & 448 & 155 & 74 \\
\hline $\mathrm{La}$ & 15.6 & 73.9 & 21.8 & 24.5 & 59.1 & 829.8 & 54.6 & 53.2 & 51.6 & 7.78 & 84.1 & 52.1 & 53.4 \\
\hline $\mathrm{Ce}$ & 54 & 171 & 44.7 & 55.3 & 133.2 & 1899.9 & 133.2 & 121 & 120 & 23.1 & 175 & 117 & 118 \\
\hline $\mathrm{Pr}$ & nd & 15.8 & 5.71 & 7.05 & 16.2 & 236.7 & 16.4 & 13.7 & 13.4 & 3.06 & 17.1 & 13.6 & 13.2 \\
\hline $\mathrm{Nd}$ & 38 & 59.4 & 20.8 & 24 & 59.5 & 888.2 & 61.8 & 51.5 & 49.1 & 17.5 & 53.5 & 47.5 & 46.3 \\
\hline $\mathrm{Sm}$ & 9.38 & 14.2 & 4.5 & 5.07 & 12.3 & 195.3 & 11.9 & 12.1 & 10.5 & 6.23 & 9.47 & 9.58 & 9.71 \\
\hline $\mathrm{Eu}$ & 1.58 & 1.75 & 2.05 & 0.503 & 0.8 & 8.8 & 1 & 0.186 & 1.19 & 0.131 & 0.94 & 0.898 & 1.01 \\
\hline $\mathrm{Gd}$ & nd & 15.3 & 4.37 & 4.02 & 9 & 148.8 & 7 & 12.4 & 8.05 & 7.32 & 7.39 & 8.21 & 8.65 \\
\hline
\end{tabular}




\begin{tabular}{|c|c|c|c|c|c|c|c|c|c|c|c|c|c|}
\hline $\mathrm{Tb}$ & 1.7 & 3.14 & 0.67 & 0.7 & 1.4 & 23.6 & 0.9 & 2.86 & 1.62 & 1.91 & 1.15 & 1.39 & 1.79 \\
\hline Dy & N.D. & 21.9 & 3.97 & 3.88 & 7.5 & 126.7 & 4.3 & 19.1 & 9.59 & 13.1 & 5.71 & 8.04 & 10.6 \\
\hline Но & N.D. & 4.9 & 0.82 & 0.67 & 1.3 & 21.8 & 0.7 & 3.93 & 1.74 & 2.59 & 1.06 & 1.46 & 1.99 \\
\hline $\mathrm{Er}$ & N.D. & 15.6 & 2.45 & 1.82 & 3.2 & 53.9 & 1.6 & 12.7 & 5.19 & 8.33 & 3.16 & 4.22 & 5.85 \\
\hline $\mathrm{Tm}$ & N.D. & 2.73 & 0.38 & 0.26 & 0.5 & 7.6 & 0.2 & 2.05 & 0.819 & 1.55 & 0.46 & 0.655 & 0.909 \\
\hline $\mathrm{Yb}$ & 5.54 & 16.5 & 2.58 & 1.6 & 2.9 & 44.7 & 1.3 & 13.1 & 5.23 & 10.6 & 2.77 & 4.2 & 5.72 \\
\hline $\mathrm{Lu}$ & 0.79 & 2.6 & 0.42 & 0.211 & 0.4 & 6.3 & 0.2 & 1.83 & 0.741 & 1.6 & 0.39 & 0.59 & 0.838 \\
\hline $\mathrm{U}$ & 0.1 & 4.37 & 1.09 & 5.42 & 12.6 & 187 & 3.7 & 20.7 & 6.2 & 56.5 & 1.9 & 6.04 & 7.17 \\
\hline Th & 0.4 & 37 & 5.18 & 18.5 & 47.2 & 673.6 & 47.8 & 77.1 & 30.1 & 20.2 & 17 & 46.1 & 28.4 \\
\hline $\mathrm{Y}$ & 58 & 145 & 21.6 & 19.5 & 35.6 & 616.6 & 18.1 & 130 & 54.2 & 105 & 26.9 & 45.8 & 57.9 \\
\hline $\mathrm{Nb}$ & 5 & 29 & 11.8 & 20.2 & 60.6 & 276.1 & 22.8 & 68.3 & 33.1 & 30.4 & 15.6 & 37.3 & 34.9 \\
\hline $\mathrm{Zr}$ & 120 & 210 & 838 & 146 & 239.6 & 2580.8 & 203.5 & 168 & 191 & 69 & 191 & 261 & 248 \\
\hline $\mathrm{Hf}$ & 3.6 & 5.3 & 18.4 & 4.3 & 7.4 & 79.6 & 6 & 7.4 & 5.6 & 5.1 & 5.8 & 7.5 & 6.9 \\
\hline $\mathrm{Ta}$ & 0.2 & 2.28 & 0.86 & 1.57 & 8.6 & 21.3 & 1.8 & 7.86 & 4.93 & 13.9 & 0.78 & 6.08 & 4.3 \\
\hline $\mathrm{Ga}$ & 21 & 23 & 22 & 23 & 32 & 54 & 23 & 26 & 24 & 30 & 19 & 23 & 21 \\
\hline$M$ & 3.32 & 2.91 & 1.64 & 1.22 & 1.27 & 4.06 & 1.22 & 1.46 & 1.32 & 1.37 & 1.44 & 1.45 & 1.45 \\
\hline$T_{Z r}\left({ }^{\circ} \mathrm{C}\right)$ & & & 933 & 792 & 833 & 833 & 822 & 792 & 807 & 817 & 799 & 827 & 821 \\
\hline
\end{tabular}

NOTES: 1. Early-Middle Ordovician geochemistry data from Pankhurst et al. (2000) and Dahlquist et al. (2008), Early Carboniferous geochemistry data from Dahlquist et al. (2010), and Middle-Late Devonian geochemistry data from Dahlquist et al. (submitted JSAES). 2. ACH-140 sample analyzed at ACTLABS. NPE-10, NPE-14 and DAL-1 analyzed at Washington State University. 3. $T_{\mathrm{Zr}}=12,900 /\left[2.95+0.85 \mathrm{M}+\ln \left(496,000 / \mathrm{Zr}^{\mathrm{melt}}\right)\right]$, where $\mathrm{D}^{\mathrm{Zr}}$, zircon/melt $=\left(496,000 / \mathrm{Zr}{ }^{\text {melt }}\right)$, is the ratio of $\mathrm{Zr}$ concentrations (ppm) in zircon to that in the saturated melt; $\mathrm{M}$ is a compositional factor that accounts for dependence of zircon solubility on $\mathrm{SiO} 2$ and peraluminosity of the melt $[(\mathrm{Na}+\mathrm{K}+2 \cdot \mathrm{Ca}) / \mathrm{Al} \cdot \mathrm{Si})$, all in cation fraction]. The geothermometer is calibrated for $\mathrm{M}=0.9$ to 1.7. Equation and $\mathrm{Zr}$ concentrations (ppm) in zircon (= 496,000 ppm) from Miller et al. (2003).

*Low total is attributed to the high $\mathrm{F}$ content.

${ }^{\dagger} \mathrm{N} . \mathrm{D} .=$ not determined.

$\mathrm{Gb}=$ Gabbro, $\mathrm{Tn}=$ Tonalite, $\mathrm{Gda}=$ Granodiorite, Monzogranite $=$ Mzg . 